\title{
Spatial Dimensions of the Influence of Urban Green-Blue Spaces on Human Health: A Systematic Review
}

DOI:

10.1016/j.envres.2019.108869

\section{Document Version}

Accepted author manuscript

Link to publication record in Manchester Research Explorer

\section{Citation for published version (APA):}

Labib, SM., Lindley, S., \& Huck, J. (2019). Spatial Dimensions of the Influence of Urban Green-Blue Spaces on Human Health: A Systematic Review. Environmental Research, 180, [108869].

https://doi.org/10.1016/j.envres.2019.108869

\section{Published in:}

Environmental Research

\section{Citing this paper}

Please note that where the full-text provided on Manchester Research Explorer is the Author Accepted Manuscript or Proof version this may differ from the final Published version. If citing, it is advised that you check and use the publisher's definitive version.

\section{General rights}

Copyright and moral rights for the publications made accessible in the Research Explorer are retained by the authors and/or other copyright owners and it is a condition of accessing publications that users recognise and abide by the legal requirements associated with these rights.

\section{Takedown policy}

If you believe that this document breaches copyright please refer to the University of Manchester's Takedown Procedures [http://man.ac.uk/04Y6Bo] or contact uml.scholarlycommunications@manchester.ac.uk providing relevant details, so we can investigate your claim.

\section{OPEN ACCESS}




\title{
Spatial Dimensions of the Influence of Urban Green-Blue Spaces on Human Health: A Systematic Review
}

\begin{abstract}
:
Background

There is an increasing volume of literature investigating the links between urban environments and human health, much of which involves spatial conceptualisations and research designs involving various aspects of geographical information science. Despite intensifying research interest, there has been little systematic investigation of pragmatic methodological concerns, such as how studies are realised in terms of the types of data that are gathered and the analytical techniques that are applied, both of which have the potential to impact results. The aim of this systematic review is, therefore, to understand how spatial scale, datasets, methods, and analytics are currently applied in studies investigating the relationship between green and blue spaces and human health in urban areas.
\end{abstract}

\section{Method}

We systematically reviewed 93 articles following PRISMA protocol, extracted information regarding different spatial dimensions, and synthesised them in relation to various health indicators.

Results and Discussion

We found a preponderance of the use of neighbourhood-scale in these studies, and a majority of the studies utilised land-use and vegetation indices gleaned from moderate resolution satellite imagery. We also observed the frequent adoption of fixed spatial units for measuring exposure to green and blue spaces based on physical proximity, typically ranging between 30 and 5000 metres. The conceptual frameworks of the studies (e.g., the focus on physical vs. mental health or the definition of exposure to green space) were also found to have an influence on the strength of association between exposure and health outcomes. Additionally, the strength and significance of associations also varied by study design, something which has not been considered systematically.

\section{Conclusion}

We, therefore, propose a set of recommendations for standardised protocols and methods for the evaluation of the impact of green-blue spaces on health. Our analysis suggests that future studies should consider conducting analyses at finer spatial scales and employing multiple exposure assessment methods to achieve a comprehensive and comparable evaluation of the association between greenspace and health along multiple pathways.

Key Words: Greenspace, Blue space, Health, Epidemiology, Exposure, GIS. 


\section{Introduction}

\subsection{Background}

An increasing interest in maintaining a healthy lifestyle and achieving better health outcomes has prompted numerous recent studies investigating possible links between the physical landscape and human health, especially in urban contexts (Bartman et al., 2019; Díaz et al., 2018; Kabisch et al., 2017; Díaz et al., 2015; Hartig et al., 2014). Multiple reviews, meta-analyses and original studies investigating these links indicate that natural environments are salutogenic and benefit both physical and mental health (Markevych et al., 2017; Twohig-bennett and Jones, 2018; Gascon et al., 2015; Ward Thompson et al., 2010). Partially in recognition of the multiple pathways through which health influences can occur, the natural environment can be conceptualised as consisting of inter-connected and multifunctional green and blue spaces, or green infrastructure, something that is particularly important in urban areas (Markevych et al., 2017; Nieuwenhuijsen et al., 2017; Hartig et al., 2014). Together green and blue spaces exert a demonstrably therapeutic effect, with their availability, accessibility, and quality linked to overall human health (Van den Bosch and Bird, 2018; Lindley et al., 2018; Gascon et al., 2015; Beyer et al., 2014). Accessible green and blue spaces have been reported to encourage exercise and social cohesion, contribute to obesity reduction, and reduce overall rates of ill health (Lindley et al., 2018). In addition to access, the presence of green and blue spaces is known to regulate local environmental hazards, for example due to associated reduction in pollution and noise (Van den Bosch and Sang, 2017; Gascon et al., 2016; Van Cauwenberg et al., 2011, Lee and Maheswaran, 2011). As a result, green and blue spaces (hereafter referred to as greenspace) are often advocated as a design element in the planning of urban spaces (Markevych et al., 2017; Nieuwenhuijsen et al., 2017).

There are large quantities of data describing health, greenspace and human exposure to potential benefits and harm (e.g., allergies) (Van den Bosch and Bird, 2018; Markevych et al., 2017; Gascon et al., 2016; Fuertes et al., 2014). Much of these data are also associated with spatial information, giving rise to a variety of statistical and geospatial methods for the analysis of associations (Musa et al., 2013). Geographic information science (GIS) is one of the foundational methods for analysing data associated with green and blue spaces, allowing data to be analysed spatially and processed into forms that allow effective examination of the relationships between spatial and geographic variables (Jia et al., 2017). Due to the ability of GIS to capture, process, and analyse the spatial components of different types of health and environmental information at different scales, GIS-based analysis has now become one of the most widely utilised methods in environmental epidemiology and related fields (Nordbø et al., 2018; Markevych et al., 2017; Musa et al., 2013).

Existing studies into the relationships between health and urban greenspace typically involve greenspace exposure assessments within different buffer zone distances (Nordbø et al., 2018; Browning and Lee, 2017; Jia et al., 2017) and at a variety of spatial scales/units of study (e.g., personal/body, 
neighbourhood, city) (Musa et al., 2013). Additionally, real time GPS tracking and geographic simulation are also being used widely in such analyses (Jansen et al., 2108; Helbich, 2018; Yin, 2013). This has raised critical questions about how variations in the data, methods and geographical scales employed in spatial analysis of greenspace benefits may influence results (James et al., 2016) and how consistent and comparable these methodological approaches are (Nordbø et al., 2018).

In this review, we will therefore:

- identify the different data, scales and geospatial methods utilised in studying greenspace and its relation to human health in urban areas;

- investigate how results vary (e.g., significant vs insignificant, positive vs negative) according to the type of association between greenspace and health indicators and their relation to spatial data and methods; and

- identify the limitations and prospects of spatial data and analytics in representing and associating greenspace, human health.

Following this review, we will recommend possible improvements in utilising spatial data, methods and tools for future studies and demonstrate the need for standard protocols, metadata, and methods for studies investigating health and the environment. Given that there are numerous existing reviews of the benefits of greenspace for health elsewhere in the literature such as Twohig-bennett and Jones, (2018); Fong et al., (2018); Van den Bosch and Sang (2017), Gascon et al., (2016); Van den Berg et al., (2015) and Lee and Maheswaran, (2011), we do not repeat that work. The present study instead focuses on the assessment of spatial scale, data, and associated methods exploring the relation between greenspace and health utilized in studies over the past decade.

\subsection{Conceptualising spatial scale and exposure assessment}

Innovations in GIS are now widely integrated into processes for understanding and improving public health, health services, and the overall wellbeing of populations (ESRI, 2018; Musa et al., 2013). The widespread use of spatial data at multiple geographic scales is common in greenspace and health related studies and has provided a new appreciation among both scholars and urban planners of the impact of urban design on health and wellbeing (Nordbø et al., 2018). Detailed technical information on GIS methods and data is widely available in textbooks and other online based resources (Longley et al., 2015; De Smith et al., 2007; ArcGIS Online Help, 2018). However for context we provide a brief summary of fundamental concepts pertinent to our review, such as scale (Figure 1), relevant spatial data types (e.g., land cover maps, satellite image derived vegetation indices and canopy layer; Figure 2), and commonly used GIS tools and techniques used in greenspace and health studies (Table 1).

\subsubsection{Conceptualising and representing spatial scale in studies of urban greenspace and health}

Spatial scale is a fundamental concept in geographical analysis and is linked to the selection of units of analysis used to represent the Area of Interest (AOI). The spatial scale of a study is important because the representation and quantification of greenspace is critical to data gathering and analysis 
(Ahern, 2007; Allen, 2012). In order to facilitate discussion, we have categorised the spatial scales that are commonly used in the literature - from micro to macro - as: the body/personal scale; the neighbourhood scale; the city/district scale (Figure 1). Each of these scales has key aspects that need to be considered when designing a study. The body/personal scale (micro-scale) varies between 10-100 meters and takes account of the immediate surroundings of the human body (Herod, 2010; Rodaway, 2002), and is therefore sensitive to any changes in environmental settings. The neighbourhood scale defines the areas where majority of the people spend large amounts of their time (Nordbø et al., 2018; Helbich, 2018; Chaix et al., 2013). The city scale has a much wider extent than the personal and neighbourhood scales, and this scale typically encompasses all of the spaces that urban dwellers habitually utilise during their daily activities (Browning and Rigolon, 2018; Helbich, 2018; Su et al., 2016).

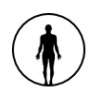

Body Scale: Immediate surrounding of the Human body (e.g. 10-100 m)

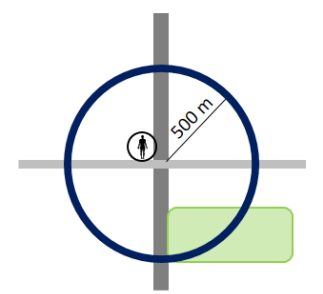

Neighbourhood (NH) Scale: Often administrative zones, such as wards, output areas, Zipcode area or buffer based (e.g. 500m) boundary from home or from neighbourhood centre.

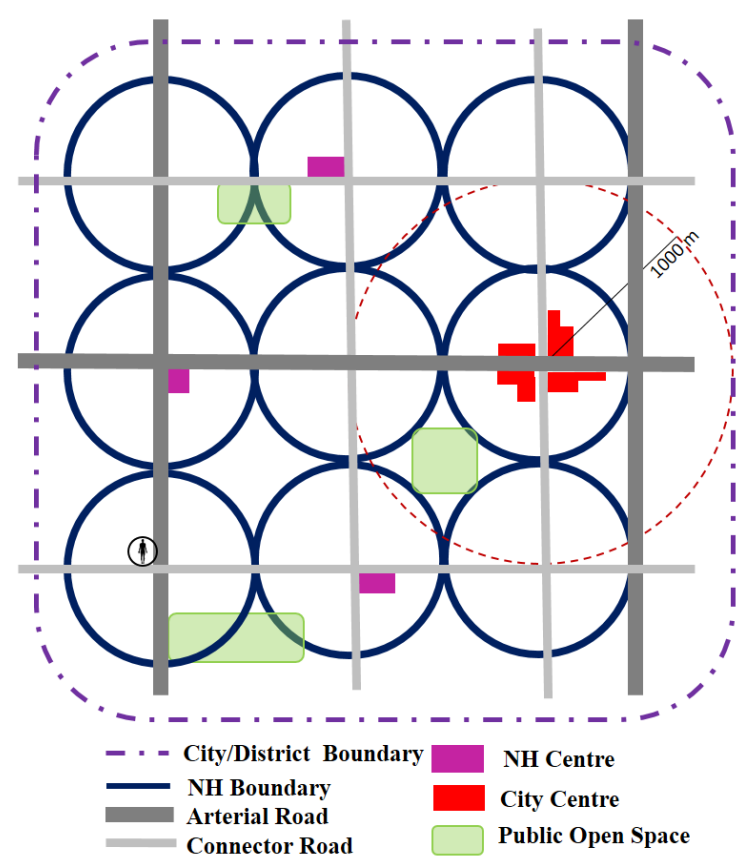

City or District Scale: Wider geographic area . Larger administrative boundary comprising several local administrative zones such as wards, or neighbourhoods.

Figure 1: Conceptualising spatial scales used in urban greenspace and health research, three scales usually considered: Body, Neighbourhood, and city/district. (City scale diagram is adopted and modified from the Western Australian Planning Commission, 2015).

We must also consider how AOIs are represented. Representations of neighbourhood scale can be divided into two categories: the neighbourhood unit, which is an allocentric model based upon administrative zones; and the neighbourhood boundary, which is an egocentric model based upon buffer distances around the home (Chaix et al., 2013; Colombo et al., 2017). Both of these approaches indicate clear-cut or sharp neighbourhood boundaries; however, in reality, such a crisp approach may not reflect human perceptions of the neighbourhood (Chaix et al., 2005). In fact, there are different ways in GIS 
to represent neighbourhoods, including the use of fuzzy boundaries that integrates a gradual transition from neighbourhood space to non-neighbourhood space, when the boundary is in a vague or indeterminate location (Wade and Sommer, 2006). A fuzzy logic approach argues that there is no clearcut neighbourhood boundary, rather neighbourhood boundary demarcation may include integrating weights defined as a decreasing function of the distance from the home of the individual for whom exposure is contextualised (Chaix et al., 2009; Chaix et al., 2005). A comparison of ego-centric neighbourhoods and fuzzy neighbourhoods can be found in Chaix et al. (2009). However, such techniques are rarely seen in the greenspace and health literature.

One key consideration here is that any attempt to aggregate data (both health and exposure) into areal units (e.g., neighbourhood or city) must take account of the Modifiable Areal Unit Problem (MAUP), which is a source of statistical bias (Su et al., 2019; Kwan, 2018; Houston, 2014; Openshaw, 1984). When any spatial data are aggregated and assigned to an arbitrary spatial zone, both the scale and the shape of the aggregation unit will influence the results in terms of the variable being measured (Houston, 2014). MAUP produces two types of effects in terms of representation and measurement of spatial data; these are the scale effect and the zoning effect (Dark and Bram, 2007). For example, varying geographic extent scales and zones may produce variations in numeric results in terms of represented spaces (e.g., parks, neighbourhoods inter alia), environmental patterns and processes, as well as the strength of associations with other variables, such as physical activity and health (Su et al., 2019; Houston, 2014; Mitra and Buliung, 2012). Importantly, increasing size of the areal unit (i.e., scale) tends to incorporate uncertainty on the strength and significance of associations between variables (Fotheringham and Wong, 1991). This significant issue will be further discussed in later sections.

Table 1: GIS processes and their common usage with the urban greenspace and health literature

\begin{tabular}{|l|l|l|l|}
\hline GIS Process & Description & Usage & Sources \\
\hline Geo-coding & $\begin{array}{l}\text { Converting addresses (e.g., } \\
\text { home, school) into } \\
\text { geographic coordinates. }\end{array}$ & $\begin{array}{l}\text { Locates receptors (e.g., } \\
\text { home or school) in } \\
\text { geographic space. }\end{array}$ & $\begin{array}{l}\text { Longley et al., } \\
\text { (2015); Jia et al., } \\
\text { (2017); Dzhambov } \\
\text { et al., (2018) }\end{array}$ \\
\hline Buffering & $\begin{array}{l}\text { Generating zones around } \\
\text { geo-coded addresses, } \\
\text { neighbourhood or other } \\
\text { spatial entities based on a } \\
\text { given Euclidian (straight } \\
\text { line) distance, travel time or } \\
\text { network distance. }\end{array}$ & $\begin{array}{l}\text { Used for greenspace } \\
\text { availability and accessibility } \\
\text { measurements. Also defines } \\
\text { exposure areas and scales. }\end{array}$ & $\begin{array}{l}\text { Browning and Lee } \\
\text { (2017); Heywood et } \\
\text { al., (2011); } \\
\text { Coombes et al. } \\
\text { (2010); Longley et } \\
\text { al., (2015) }\end{array}$ \\
\hline
\end{tabular}




\begin{tabular}{|c|c|c|c|}
\hline $\begin{array}{l}\text { Distance } \\
\text { measurement }\end{array}$ & $\begin{array}{l}\text { Estimating Euclidian or } \\
\text { network (route-based) } \\
\text { distances between two } \\
\text { points. Includes physical } \\
\text { distance and cost-distance } \\
\text { (e.g., time). Also, straight } \\
\text { line buffers around certain } \\
\text { points or lines. }\end{array}$ & $\begin{array}{l}\text { Usually used for buffers, } \\
\text { also to measure the fixed or } \\
\text { shortest distances to the } \\
\text { nearest greenspace and geo- } \\
\text { coded locations, usually } \\
\text { used for accessibility } \\
\text { determination. }\end{array}$ & $\begin{array}{l}\text { Heywood et al., } \\
\text { (2011); Forsyth, } \\
\text { (2012); Kim et al., } \\
\text { (2016) }\end{array}$ \\
\hline $\begin{array}{l}\text { Overlay } \\
\text { analysis }\end{array}$ & $\begin{array}{l}\text { Combining different spatial } \\
\text { layers (e.g., neighbourhood } \\
\text { zones, tree canopy, land } \\
\text { use) with various attributes } \\
\text { allowing discovery of co- } \\
\text { located or proximity } \\
\text { relations among them. } \\
\text { Distinct from spatial query. }\end{array}$ & $\begin{array}{l}\text { Used for establishing } \\
\text { aggregate summaries of } \\
\text { exposure variables and also } \\
\text { associations with health and } \\
\text { other socio-economic } \\
\text { information for particular } \\
\text { spatial scales. }\end{array}$ & $\begin{array}{l}\text { Longley et al., } \\
\text { (2015); Heywood et } \\
\text { al., (2011); Jia et } \\
\text { al., (2017); Glazer } \\
\text { et al. (2018) }\end{array}$ \\
\hline $\begin{array}{l}\text { Spatial } \\
\text { statistics and } \\
\text { other spatial } \\
\text { analyses }\end{array}$ & $\begin{array}{l}\text { Using spatial and/or } \\
\text { integrated temporal data to } \\
\text { analyse spatial distributions } \\
\text { and patterns. Spatial } \\
\text { statistical techniques are } \\
\text { distinct from classical } \\
\text { statistics, frequently relying } \\
\text { on the assessment of spatial } \\
\text { autocorrelation and local } \\
\text { weighting (e.g., in } \\
\text { geographically weighted } \\
\text { regression, Moran 'I). } \\
\text { Spatial autocorrelation can } \\
\text { be defined as "the similarity } \\
\text { between samples for a } \\
\text { given variable as a function } \\
\text { of spatial distance" (Diniz- } \\
\text { Filho et al. (2003:54). }\end{array}$ & $\begin{array}{l}\text { Used for estimating density } \\
\text { (e.g., kernel density or } \\
\text { density of greenspace, } \\
\text { population, and land use } \\
\text { densities to represent built } \\
\text { environment factor) and } \\
\text { conducting interpolation, } \\
\text { (e.g., of environmental } \\
\text { phenomena such as air } \\
\text { pollutant concentrations). } \\
\text { Can also be used to explore } \\
\text { local variation in global } \\
\text { regression analysis of health } \\
\text { and greenspace associations } \\
\text { and understanding the spatial } \\
\text { autocorrelation among } \\
\text { greenspace and health } \\
\text { variables (e.g., Moran 'I). }\end{array}$ & $\begin{array}{l}\text { Wade and Sommer, } \\
\text { (2006); Jia et al., } \\
\text { (2017); Forsyth, } \\
\text { (2007); Sarkar et } \\
\text { al., (2013); Helbich } \\
\text { et al., (2018); } \\
\text { Browning and } \\
\text { Rigolon, (2018) }\end{array}$ \\
\hline $\begin{array}{l}\text { Geo- } \\
\text { Simulation }\end{array}$ & $\begin{array}{l}\text { Spatial and temporal } \\
\text { simulation of objects and } \\
\text { people for future scenarios } \\
\text { analysing alternate built } \\
\text { environments, population } \\
\text { and natural settings. }\end{array}$ & $\begin{array}{l}\text { Used to simulate use of } \\
\text { greenspace and other built } \\
\text { environment factors related } \\
\text { to human use of greenspace } \\
\text { under present and future } \\
\text { scenarios, such as agent- } \\
\text { based modelling. }\end{array}$ & $\begin{array}{l}\text { Yin, (2013); } \\
\text { Longley et al., } \\
\text { (2015) }\end{array}$ \\
\hline
\end{tabular}



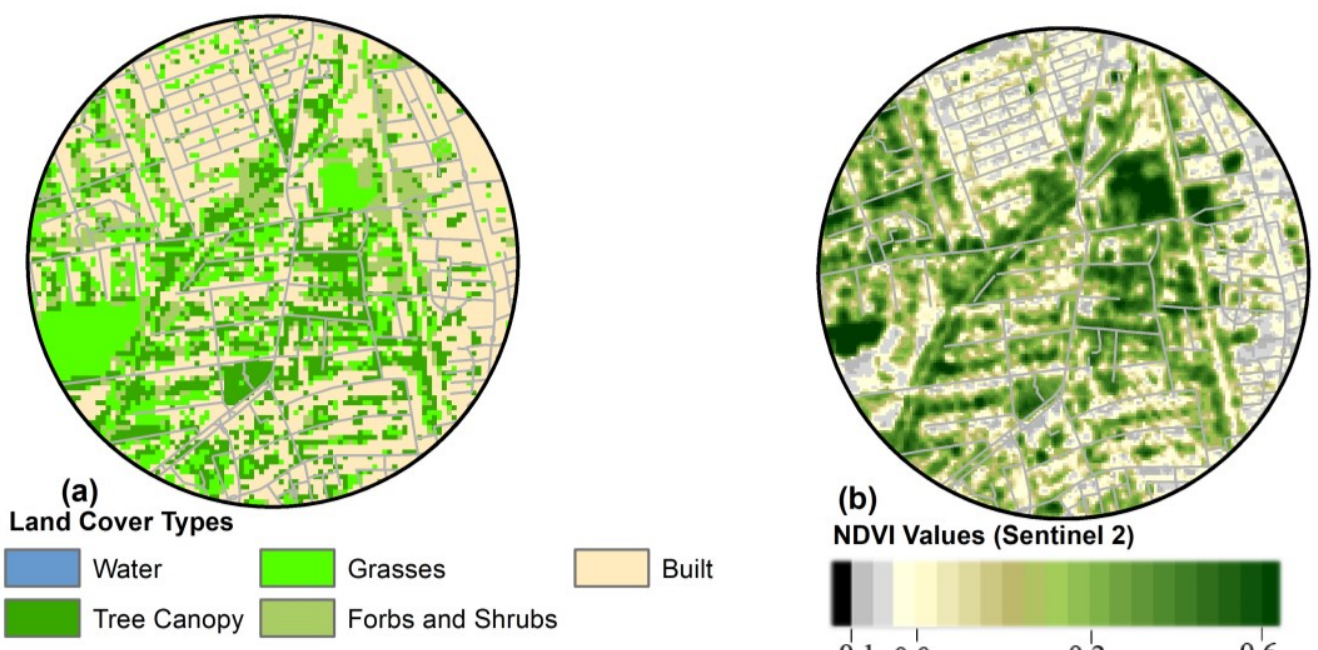

NDVI Values (Sentinel 2)
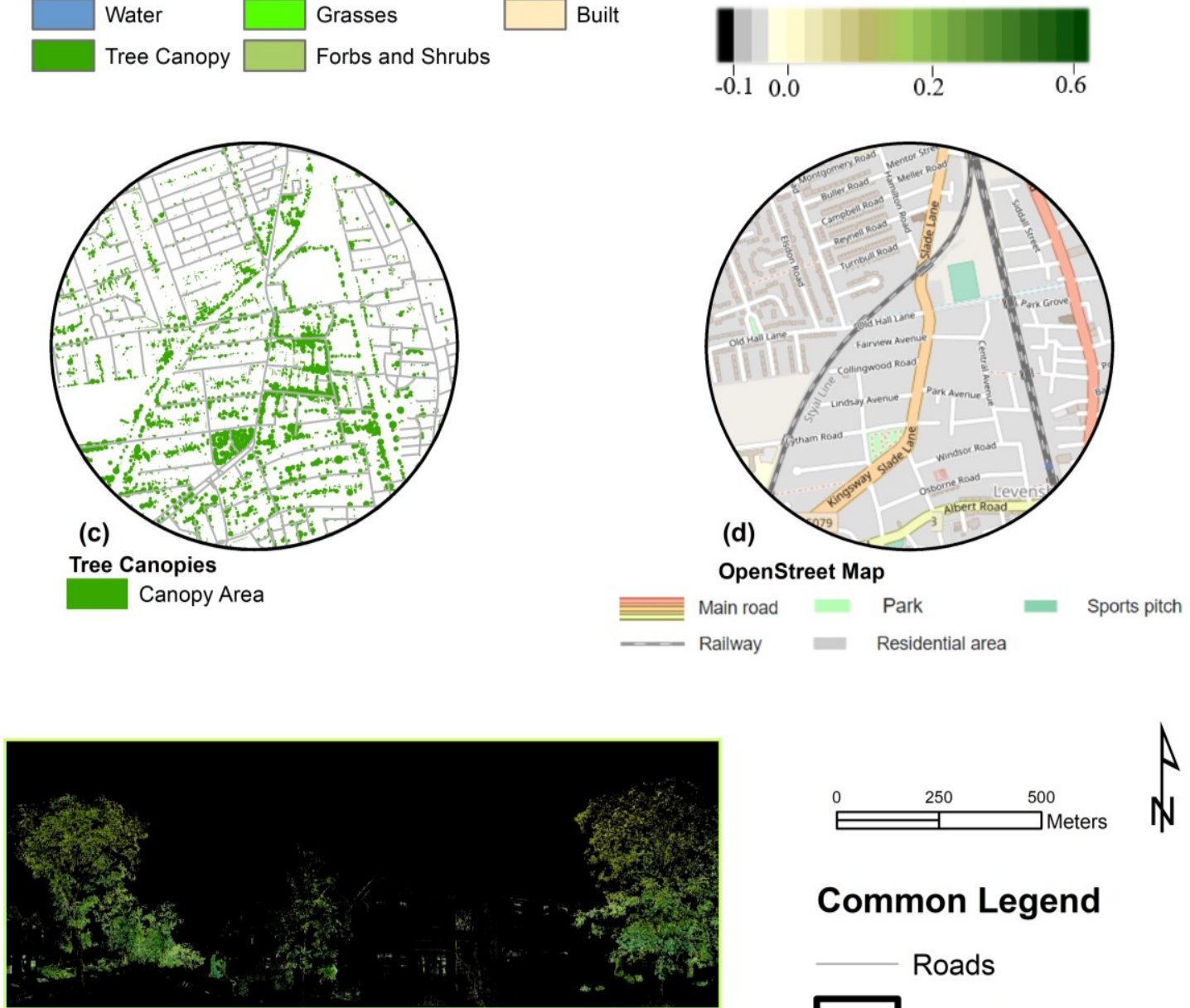

\section{Common Legend}

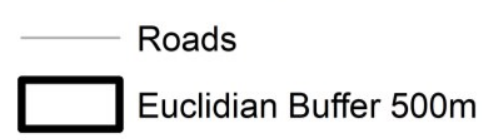

(e) Google Street View 360 Degree Image Greeneries

(c) Crown copyright and database right (2018)

Figure 2: Examples of different representations of greenspace/greenness according to data type and source (a) Land use and land cover types derived from classification of remotely sensed satellite imagery (Source: Dennis et al., 2018) (b) remotely sensed vegetation indices such as the Normalised Differential Vegetation Index (c) digitised tree canopy cover (Source: City of Trees, 2011) (d) OpenStreetMap standard layers, (e) Google Street View image showing only the green pixels indicating vegetation. 


\subsubsection{Conceptualising and representing spatially explicit forms of greenspace exposure assessment}

How people experience natural surroundings within AOIs is one of the fundamental questions posed by current studies focusing on the health benefits of urban greenspace (Nordbø et al., 2018). For the purposes of this review, we have categorised greenspace exposure into three broad types: (a) availability, (b) accessibility, and (c) visibility. The availability of greenspace refers to the physical amount of greenspace (e.g., the area or number of parcels available within a defined spatial distance from homes, schools, or other locations of interest (Bratman et al., 2019; Dadvand and Nieuwenhuijsen, 2019). Accessibility to greenspace is defined as the spatial proximity of greenspace to locations of interest (e.g., using buffer zones, distances, or travel times to the nearest parcel; Ekkel and De Vries, 2017). The visibility of greenspace refers to the amount of greenness that can be seen visually from a particular location of interest (Figure 3). These categories were derived from definitions of greenspace exposure and pathways provided in previous review articles (Hartig et al., 2014; Markevych et al., 2017; Houlden et al., 2018; Lee and Maheswaran, 2011).

Each of the three categories is related to one or more different 'pathways' through which greenspace influences health, such as physical activity, stress reduction, air quality, heat mitigation, and social cohesion (Lindley et al., 2018; Nieuwenhuijsen et al., 2017; Markevych et al., 2017; Hartig et al., 2014). There are important differences between greenspace exposure due to availability and exposure due to visibility of greenness, both of which are different from accessibility. For example, although pathways will overlap, category (a): availability may be particularly associated with physical environmental processes, such as the regulation of the local environment (Nowak et al., 2014; Dadvand et al., 2012; James et al., 2016). Whereas category (b): accessibility might be more associated with human behaviour, such as activity rates or socialising (Ekkel and De Vries, 2017; Van den Bosch and Bird 2018; Hartig et al., 2014); and category (c): visibility might be more functional in terms of restoration and the attention-retention effects of nature visibility (Ulrich, 1984; Kaplan and Kaplan, 1989).

The three exposure types we used in this review are comprehensive in terms of the way nature exposure is usually measured spatially in the current literature. However, other dimensions of exposure may further modify the health effects of greenspace exposure, such as perceived proximity/access to greenspace, the experience of nature (e.g., interaction, dose), and the quality of greenspace (Bartman et al., 2019; Sefcik et al., 2019; Silva et al., 2018; Van den Bosch and Bird 2018; Van Dillen et al., 2012; Giles-Corti and Donovan, 2002). The scope of this review was primarily focused on objective spatial categories measured in terms of spatially explicit methodologies. 

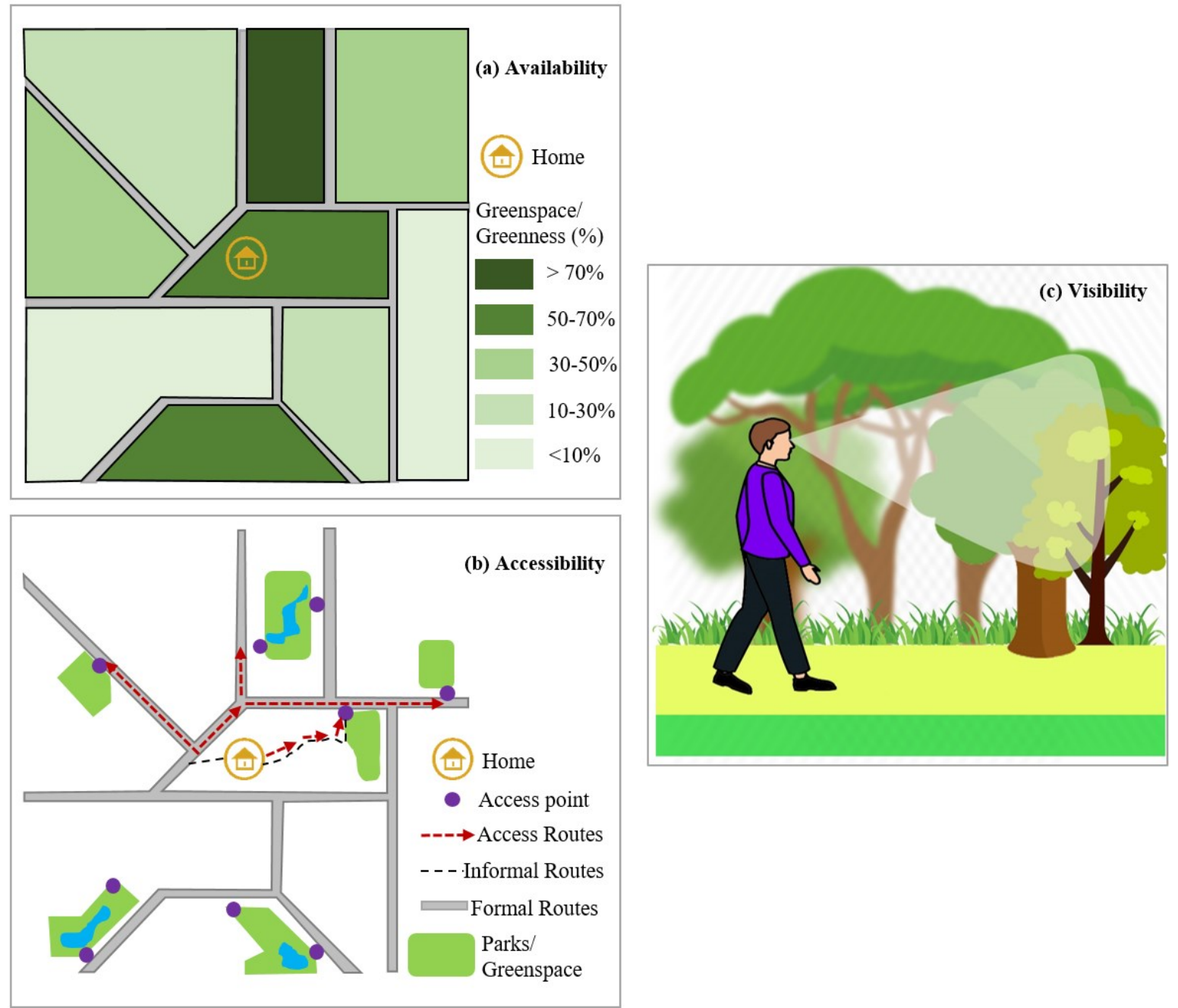

Figure 3: Conceptualising spatially explicit greenspace exposure types: (a) availability of greenspace or greenness in different neighbourhoods (e.g., percentage, numbers, and area/size) (b) accessibility to greenspace from home (e.g., numbers of accessible parcels, distance to parcels) (c) visibility of greenspace while travelling or around the home.

A range of data sources are available to represent the different exposure categories, such as satellite image indices, tree canopy data, or land cover data (Figure 2). Since data have different spatial resolutions and data types, they also have an influence on how effectively they represent factors of interest (Reid et al., 2018).

\section{Methodology}

This systematic review was conducted according to the principles of the Preferred Reporting Items for Systematic Reviews and Meta-Analyses (PRISMA) protocol (Liberati et al., 2009). It was undertaken in order to critically evaluate articles related to spatial data and methods used when investigating the health effects of greenspace. An extensive literature search was conducted, and data extracted and synthesised using the PRISMA guidelines, following the themes identified in section 1.2. 


\subsection{Search strategy}

We searched for articles published between January 1, 2009 and December 31, 2018 in Web of Science, Scopus, and PubMed using different combinations of keywords focused on the objective of this review paper. Our greenspace-related key words included four themes (Table 2) - greenspace, health indicators, target population, and geo-spatial data and spatial analytics related. Some key words were selected based on previous review papers such as Van den Bosch and Sang (2017); Browning and Lee (2017), and Gascon et al. (2015). Other key words - and our subsequent selection of final papers for inclusion in this review - were informed by the fundamental concepts related to scale, data types, GIS processes, and exposure assessment, as identified in the previous section. These concepts also provided the foundation for how information was extracted and analysed from the selected papers. We used, "AND" and "OR" Boolean logic to perform searches with combinations of key words. The exact search strings and Boolean logic used to perform the search in all three databases are listed in Table 1S in the supplementary document.

Table 2: Keyword combinations for searching the literature

\begin{tabular}{|c|c|c|c|}
\hline Green/Blue space related & Health Indicators & GIS related & Population \\
\hline $\begin{array}{l}\text { greenspace } \\
\text { blue space } \\
\text { green and blue spaces } \\
\text { green infrastructure } \\
\text { urban greenspace } \\
\text { urban park } \\
\text { neighbourhood greenness } \\
\text { urban tree }\end{array}$ & $\begin{array}{l}\text { health } \\
\text { public health } \\
\text { mental health } \\
\text { physical health } \\
\text { obesity } \\
\text { walkability } \\
\text { restoration }\end{array}$ & $\begin{array}{l}\text { GIS } \\
\text { Geographic } \\
\text { information } \\
\text { PPGIS } \\
\text { VGIS } \\
\text { agent based model }\end{array}$ & $\begin{array}{l}\text { Children } \\
\text { Older Adults } \\
\text { Adults }\end{array}$ \\
\hline
\end{tabular}

The searches located 2431 articles (excluding duplicates) related to the themes. Two stages of screening and evaluation were conducted to select articles to review. For Stage 1 we screened and excluded articles if they: (1) inadequate topic (e.g., title or abstract do not match the main research objectives), (2) focus in disease ecology, or pollution based epidemiology, (3) not original research, (4) not peer reviewed, and (5) not written in English. After screening and remove articles based on the exclusion criteria of Stage 1, for Stage 2 (full text review), the articles were excluded if they;

i. did not use spatially explicit methods in evaluating the relation between greenspace and health indicators.

ii. did not directly or indirectly measure or observe aspects of health in terms of either physical or mental health

iii. did not focus on applying more than one spatially explicit methodology (e.g., buffering, distance measuring, Table 1) in the process of data extraction or analysis 
After the first screening stage, a total of 2182 articles were excluded from the initial list of identified articles, leaving 249 for full-text evaluation. At Stage 2, the 249 articles provided references to 10 others (i.e., snowballing), so ultimately, 259 articles were read in detail. Of the 259 Stage 2 articles read, 93 were included for review in this paper based upon criteria selected for Stage 2 evaluation. A flow diagram of the article screening and exclusion process is presented in Figure 4.

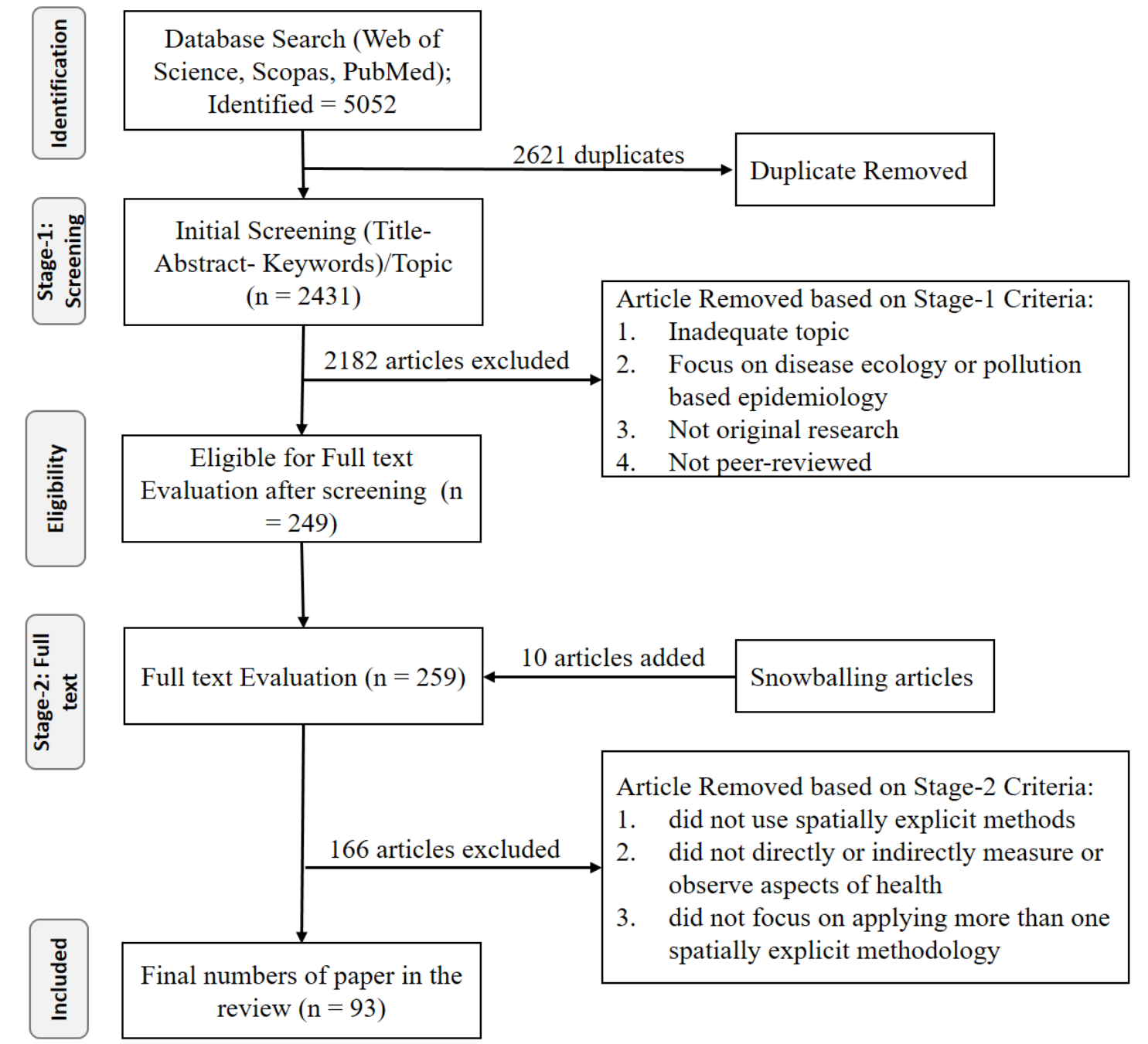

Figure 4: Search approach and selection of the reviewed articles.

\subsection{Data extraction and synthesis}

Following the PRISMA protocol, we extracted information focusing upon the objectives of the review. Utilising the review criteria (Table 3) the extracted data, included authors information, year of publication, study area, study design and sample size. In addition, we collected and synthesised specific information focusing upon health indicator measurements, spatial data sources; spatial analytical methods used (e.g., buffering, shortest distance estimation, network analysis); greenspace exposure category and assessment methods (in terms of availability, accessibility and visibility); and statistical modelling approaches (Table 3). All extracted data were recorded in a tabulated summary for each article (included in the supplementary document) and further analysed in Excel and SPSS (v 20) for 
frequency and cross-tab analysis of the different themes. Associations between greenspace and health indicators are presented as positively significant, insignificant, or not available. Additionally, these relations are further analysed using cross-tabulation among different health and greenspace related data presented as a Sankey diagram provided to aid in visualisation of the relationships (Figure 5). The lead author compiled, extracted, and synthesised data from the selected articles. The second and third authors monitored the process, and all authors contributed to design and interpretation.

Table 3: Review criteria used to select papers and extract information

\begin{tabular}{|c|c|c|}
\hline Themes & Criterion & Possible Entries \\
\hline \multirow{4}{*}{$\begin{array}{l}\text { General } \\
\text { Information of } \\
\text { the paper }\end{array}$} & Source & bibliographic information \\
\hline & Type of paper & research (peer reviewed) \\
\hline & Context & urban, sub-urban \\
\hline & Study design type & cross-sectional, longitudinal \\
\hline \multirow[t]{3}{*}{ Health Indicators } & Health types & physical, mental, or both \\
\hline & $\begin{array}{l}\text { Health indicators } \\
\text { measurements }\end{array}$ & $\begin{array}{l}\text { Objective health (e.g., continuous tracking or tests), } \\
\text { subjective (e.g., self-reported, and questionnaire } \\
\text { surveys). }\end{array}$ \\
\hline & Indicator types & $\begin{array}{l}\text { Anthropometric information (e.g., BMI, lung function, } \\
\text { blood pressure), physical activities (e.g., moderate- } \\
\text { vigorous physical activity-mvpa, running, step counts), } \\
\text { mental health (e.g., stress and anxiety, depression, life } \\
\text { satisfaction). }\end{array}$ \\
\hline \multirow{5}{*}{$\begin{array}{l}\text { Spatial scale, } \\
\text { extent, data }\end{array}$} & Spatial scale & body/personal, neighbourhood, city/ districts \\
\hline & Spatial data for greenspace & $\begin{array}{l}\text { satellite image derived indices, land use and land cover, } \\
\text { tree canopies, web-maps, other geo-tagged images (e.g., } \\
\text { street view images) }\end{array}$ \\
\hline & $\begin{array}{l}\text { Objective activity } \\
\text { measurement }\end{array}$ & GPS tracks for activity observation. \\
\hline & Built-environment data & $\begin{array}{l}\text { spatially explicit built-environment data such as land use } \\
\text { diversity, street connectivity, connectivity, walkability }\end{array}$ \\
\hline & $\begin{array}{l}\text { Geographic extent for } \\
\text { exposure assessment }\end{array}$ & $\begin{array}{l}\text { Geo-coded address, buffers (Euclidian distance, network } \\
\text { distance), administrative zone. }\end{array}$ \\
\hline $\begin{array}{l}\text { The exposure and } \\
\text { accessibility of } \\
\text { greenspace }\end{array}$ & Exposures assessment types & $\begin{array}{l}\text { availability of greenspace or greenness, accessibility } \\
\text { (e.g., distance to access), visibility of greenness at certain } \\
\text { location, others (e.g., time spent) }\end{array}$ \\
\hline \multirow[t]{2}{*}{$\begin{array}{l}\text { Association } \\
\text { between health } \\
\text { and greenspace } \\
\text { exposures }\end{array}$} & $\begin{array}{l}\text { How the relation between } \\
\text { health and greenspace } \\
\text { assessed? }\end{array}$ & $\begin{array}{l}\text { statistical modelling (e.g., logistic, linear regressions) } \\
\text { and correlation analysis, spatial correlation, spatial } \\
\text { regression (e.g., land use regression; autoregressive } \\
\text { model), overlay analysis, geographic simulation }\end{array}$ \\
\hline & Confounders & $\begin{array}{l}\text { Any confounders considered (e.g., personal attributes- } \\
\text { age, gender, employment status, race). }\end{array}$ \\
\hline
\end{tabular}

\section{Results}

This section summarises the characteristics of the review papers according to the selected themes identified in Section 2. A summary of the reviewed papers is presented in Table S2 in the supplementary document.

\subsection{General study characteristics and design}

Out of the 93 studies reviewed, more than half $(n=57)$ had been conducted and reported in the past three years, a reflection of the increasing interest in health studies involving greenspace (Figure 
5a). The reviewed articles were published in 18 scientific journals, the majority of which are multidisciplinary (e.g., Environmental Research, Health and Place, International Journal of Environmental Research and Public Health, Environment International, Landscape and Urban Planning, Environmental Health Perspectives). Articles covered studies from 17 countries, with few examples from the developing world (Figure 5b). Two studies considered population from multiple regions (Schipperijn et al., 2017; Veitch et al., 2016). Due to the fact that cross-sectional studies can be conducted quickly and have relatively low resource requirements, most of the studies in the present review are cross-sectional in design $(n=79)$.

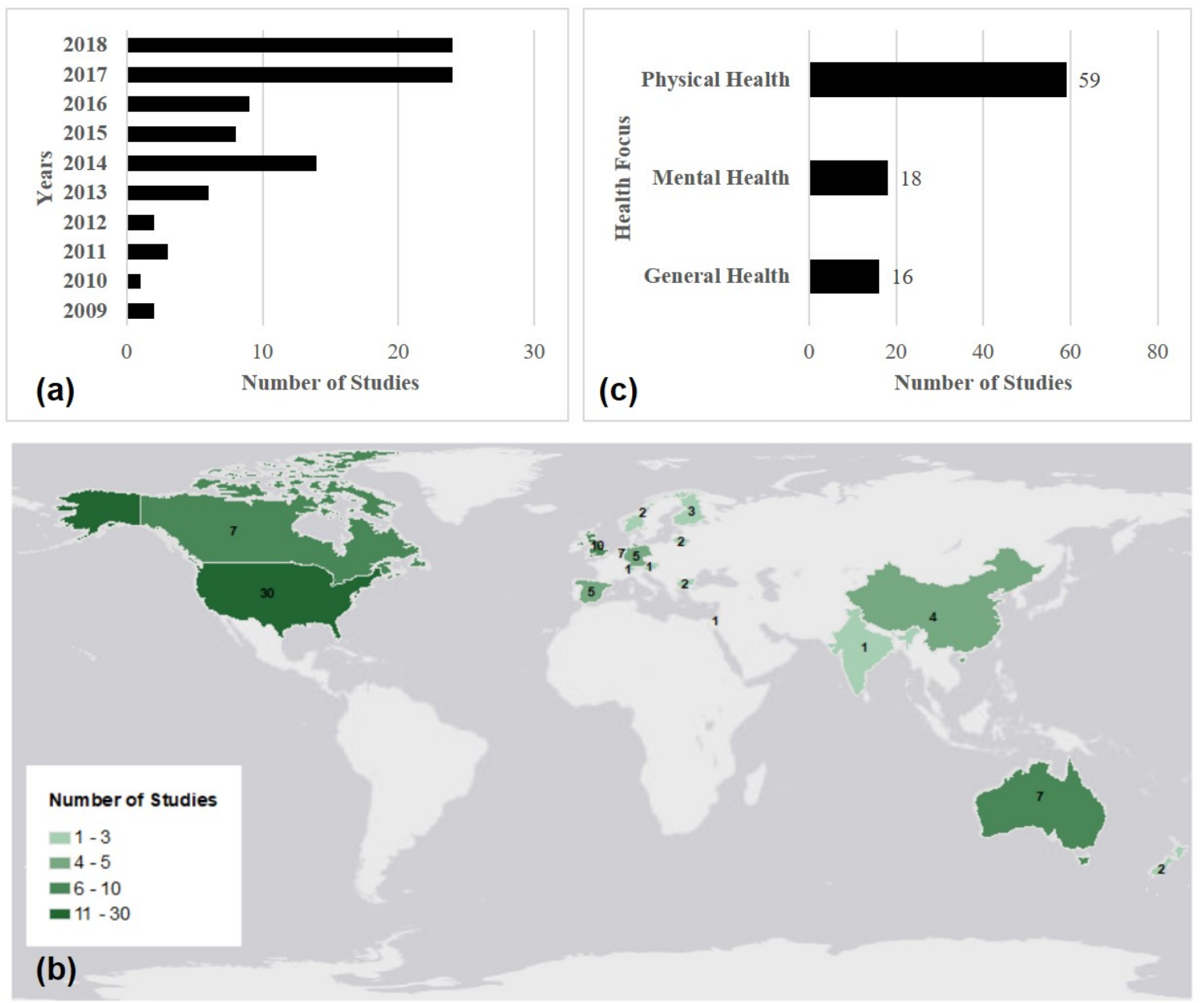

Figure 5: Study characteristics based on (a) the numbers of articles published by year, (b) the geographic locations of the studies with the darker green indicating larger article counts, and (c) the health focus of reviewed articles.

\subsection{Study emphasis and confounding variables}

The majority of the articles that took an explicitly spatial approach were focused on physical health $(n=59)$, with 18 studies exploring the impact of greenspace on mental health. The rest of the articles reported on investigations into both physical and mental health or overall general health and 
wellbeing $(n=16)$ (Figure 5c). Amongst the physical health studies, BMI, physical activities, walking behaviour, obesity, blood pressure, and birth weight were commonly examined, with multiple physical health indicators often investigated in a single study. For mental health studies, general mental health, depression, anxiety, stress, emotional wellbeing, and child development were of particular interest, with autism also studied in one article. Amongst the 18 mental health articles, 11 studies had been published between 2016 and 2018, and the majority of the articles that studied general health $(n=14)$ had been published after 2015 .

Most of the articles focused on an adult population $(n=59)$ ages 18 to 65 years old. However, a spatial approach was also taken in studies of other demographic groups, including for children $(n=$ $21)$, older adults $(n=6)$, both adults and children $(n=1)$. Five articles did not mention any particular target population but focused instead on aspects of greenspace contact and use (e.g., walking behaviour, the use of greenspace, and emotional attachments in general). The sample size of the target populations varied between 75 (minimum) and 4,284,680 (maximum). Twenty-six reviewed articles used sample sizes of less than 500 .

Most of the studies in this review $(n=85)$ controlled for confounders. We observed 66 unique general confounders considered in the reviewed articles. The most common confounders were often socio-demographic data, including age, gender, education, income, ethnicity, race, marital status, employment status, and family size. Additionally, personal attributes, such as BMI, alcohol consumption, smoking, and physical activities, were also applied in several studies (Figure 6). The entire list of confounding variables used in these studies is presented in Table $3 \mathrm{~S}$ in the supplementary documentation. Few studies intentionally explored variations in health outcomes in relation to the sociodemographic and personalised attributes of the sample. We observed that, in addition to the use of generic socio-demographic confounders, the consideration of confounders was usually dependent on the health focus of the study. Physical health focus studies often considered physical activities, such as the presence of chronic disease, history of sickness, parental health (e.g., asthma, hypertension), statin and antibiotic use, preterm birth, and car-ownership, as confounders (de Keijzer et al., 2019; Stewart et al. 2018; Yeager et al., 2018; Andrusaityte et al., 2016). Mental health studies utilised variables such as stressful life events, deprivation, poverty, crime rates, and social networks (Sarkar et al., 2018; Dzhambov et al., 2018c; Ihlebæk et al., 2018; McEachan et al., 2015; ). Glazer et al. (2018) observed that, depending on the presence of confounding variables, the statistical significance varies, and they argued that the selection of an optimal degree of confounding variables should be considered carefully. 


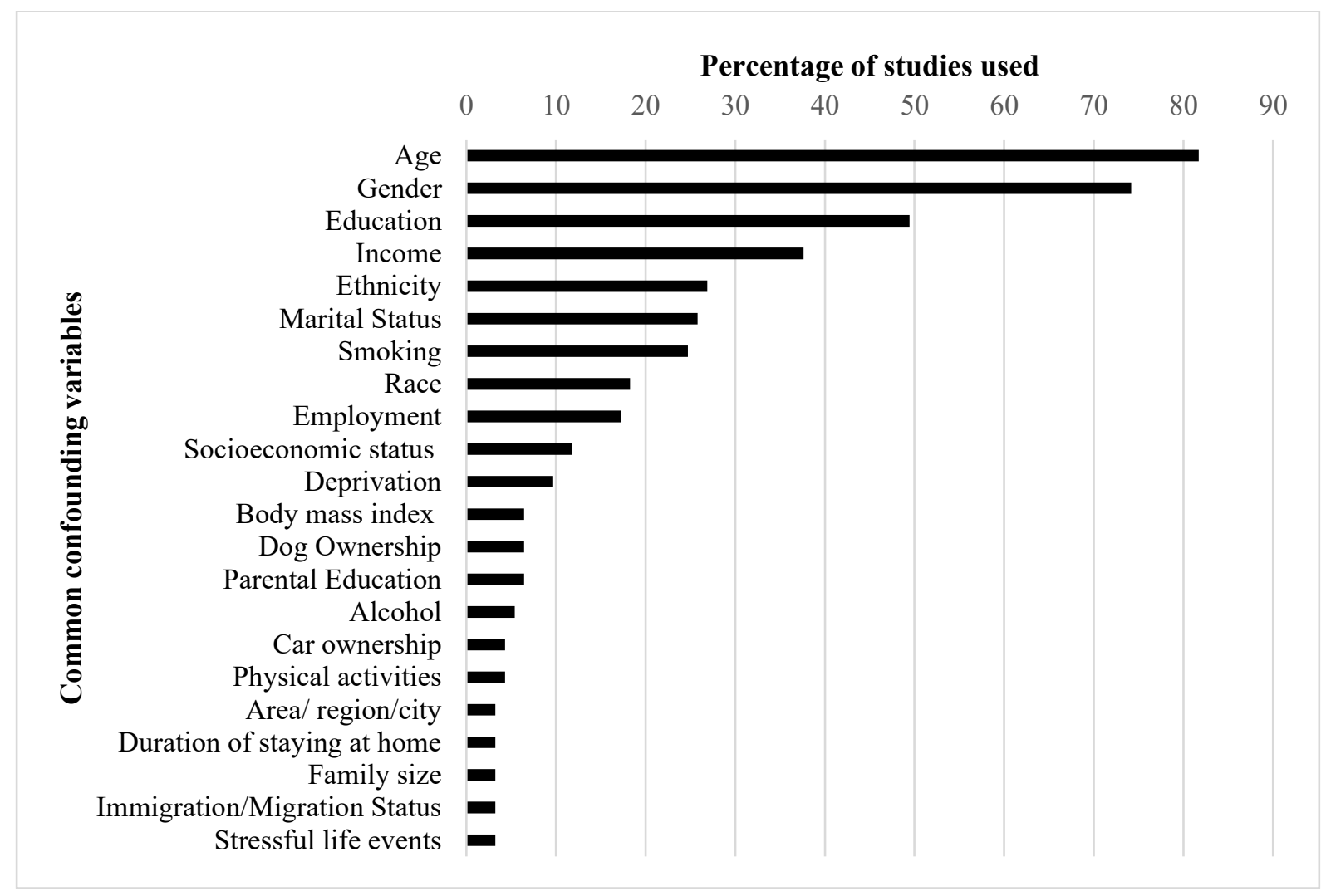

Figure 6: Confounding variables usually considered (i.e., used in a minimum of 3 articles), organised in descending order.

\subsection{Overview of health indicators and their relations with spatial dimensions}

The studies reviewed used a mix of subjective and objective health indicators to represent human health conditions. Indicators also varied in terms of whether they were direct (e.g., body mass index) or proxy measures (e.g., steps). Most of the articles (83\%) used subjective or self-reported health indicators to measure the health conditions of the participants. The data were usually collected from cohort surveys and national and local health databases, including survey protocols, such as the general health questionnaire (Dzhambov et al., 2018a; Van den Berg et al., 2017; Triguero-Mas et al., 2015; Sarkar et al., 2013); the short-form health survey (Van den Berg et al., 2017; Triguero-Mas et al., 2015); and WHO-5 and MHI-5. In 13 of the studies (approximately 14\%); objective data collection was achieved by the adoption of geospatial data capturing devices, including GPS devices, smartphones, or accelerometers to capture walking speed, direction, and location (Triguero-Mas et al., 2017a; TrigueroMas et al., 2017b; Schipperijn et al., 2017; Matisziw et al., 2016; Jansen et al., 2017; Brown et al., 2014; Dunton et al., 2014). In addition, Zandieh et al. (2017) used GPS-based walking measurements along with interviews to not only capture objective health behaviour but to capture the individuals' perceptions of the places used for physical activity. 


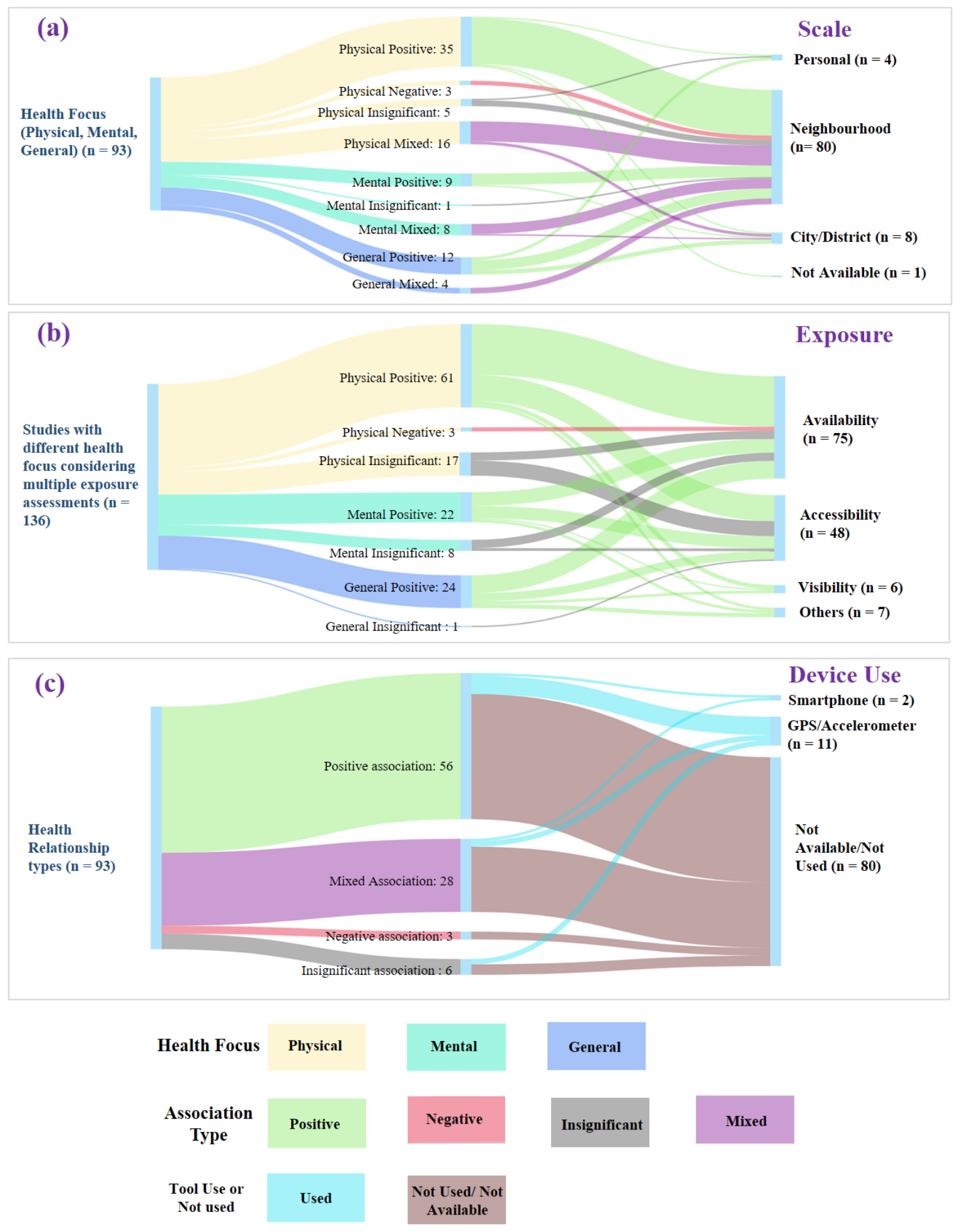

Figure 7: Relationships among health indicators and greenspace exposure type, scale of study, and data collection method. The left side includes the health aspects (e.g., types of health considered), and the right side includes the spatial aspects of studies (i.e., scale, exposure, and device use). (a) Associations between health and different spatial scales; (b) association between health indicators and exposure assessment types (including multiple exposures); (c) use of GPS/Accelerometer and smartphone for health indicators and their outcomes (positive, negative, insignificant and mixed). 
Figure 7 illustrates that most of the studies (86\%), regardless of focus (i.e., physical, mental, or general), were conducted at the neighbourhood scale, and most recorded a significant positive relationship between health and greenspace (Figure 7a). Only a few studies focused on physical or mental wellbeing, and these studies indicated an insignificant relationship between health and greenspace at the neighbourhood scale (Stewart et al. 2018; Vogt et al., 2015; Quynh Huynh et al. 2013; Michael et al., 2014) and at the personal scale (Burgoine et al., 2015). However, several studies (27\%) found mixed associations between green space and health at the neighbourhood scale. These studies observed that, among multi-exposure and health assessment, some of the relationships are significant, and others are insignificant. These variations indicate inconsistency in associations observed at different scales; however, general studies at the neighbourhood and district/city scales have observed at least one positive association between health and greenspace. At the personal scale, the relationships remain largely unexplored.

Most of the studies considered availability or accessibility as the exposure category (Figure 7b). Among the reviewed articles, 75 considered availability exposure, and among these, a majority found positive associations $(n=60)$, three found negative associations (Wilhelmsen et al., 2017 for BMI; Andrusaityte et al., 2016 for asthma; Astell-Burt et al., 2014 for skin cancer), and 12 studies identified significant associations with availability. Accessibility was the second-highest exposure assessment approach used by 48 studies, among which a majority $(n=34)$ found positive associations with accessibility to greenspace, and 14 studies observed insignificant associations. Visibility and other exposure assessments were least used in the reviewed articles. Only six studies used visibility exposure, and all found positive relationships between visibility and health. Seven studies considered additional measurements of exposure such as time spent or frequency of visit, and these studies also indicated positive associations (Figure $7 \mathrm{~b}$ ). Overall, the results supported the positive relationships between greenspace availability, accessibility, and visibility and health indicators.

It should be noted that some of the studies in this review considered more than one exposure type or more than one health indicator. Several studies observed mixed results, such as significance in one exposure assessment but insignificance in another assessment (Klompmaker et al., 2018; Glazer et al. 2018; Jonker et al., 2014; Kaczynski et al., 2014) or significance in one type of greenspace metric but insignificance in another metric (Gascon et al., 2018; Dzhambov et al., 2018c; Abelt and McLafferty, 2017). A few studies also identified variation in significance depending on the use of mediation analysis, such as time spent in greenspace, air pollution, restorative quality (Dzhambov et al., 2018a; Van den Berg et al., 2017). Additionally, some studies observed significance for one health indicator and insignificance for other health indicators (Ihlebæk et al., 2018; Müller et al., 2017; Markevych et al., 2014a; Dadvand et al., 2014). These studies illustrated that there are variations in associations between greenspace and health, depending not only on a study's health focus and indicators but also on the type of exposure being examined and the metric used to assess the exposure. 
We observed that only a few studies ( $n=13$, Figure 7c) used GPS/accelerometer or smartphone devices to objectively monitor some health indicators such as walking, MVPA, and visiting greenspace. Among these 13 studies, eight studies reported significant positive associations between greenspace and health, the remaining five studies indicated either insignificance (Stewart et al. 2018; Burgoine et al., 2015) or mixed associations between greenspace and health (Triguero-Mas et al., 2017a; Schipperijn et al., 2017; Matisziw et al., 2016). As a whole, the use of GPS/accelerometers and smartphones are relatively less common in studies in this review. Further discussion of these studies with regard to various spatial dimensions is presented in the following sections, highlighting how the positive and insignificant association between health and greenspace exposures varies according to different scales, exposure areas, data, and even different exposure types.

\subsection{Scales and geographic exposure area}

\subsubsection{Spatial scale of studies}

Figure 1 illustrates examples of commonly used units to represent neighbourhood and personal scales found in the reviewed articles. Among the articles in this review, the most commonly used scale was the urban neighbourhood scale $(n=80)$. Eight studies were conducted using a city/district scale (Figure 8). Only four studies considered a personal/body scale.

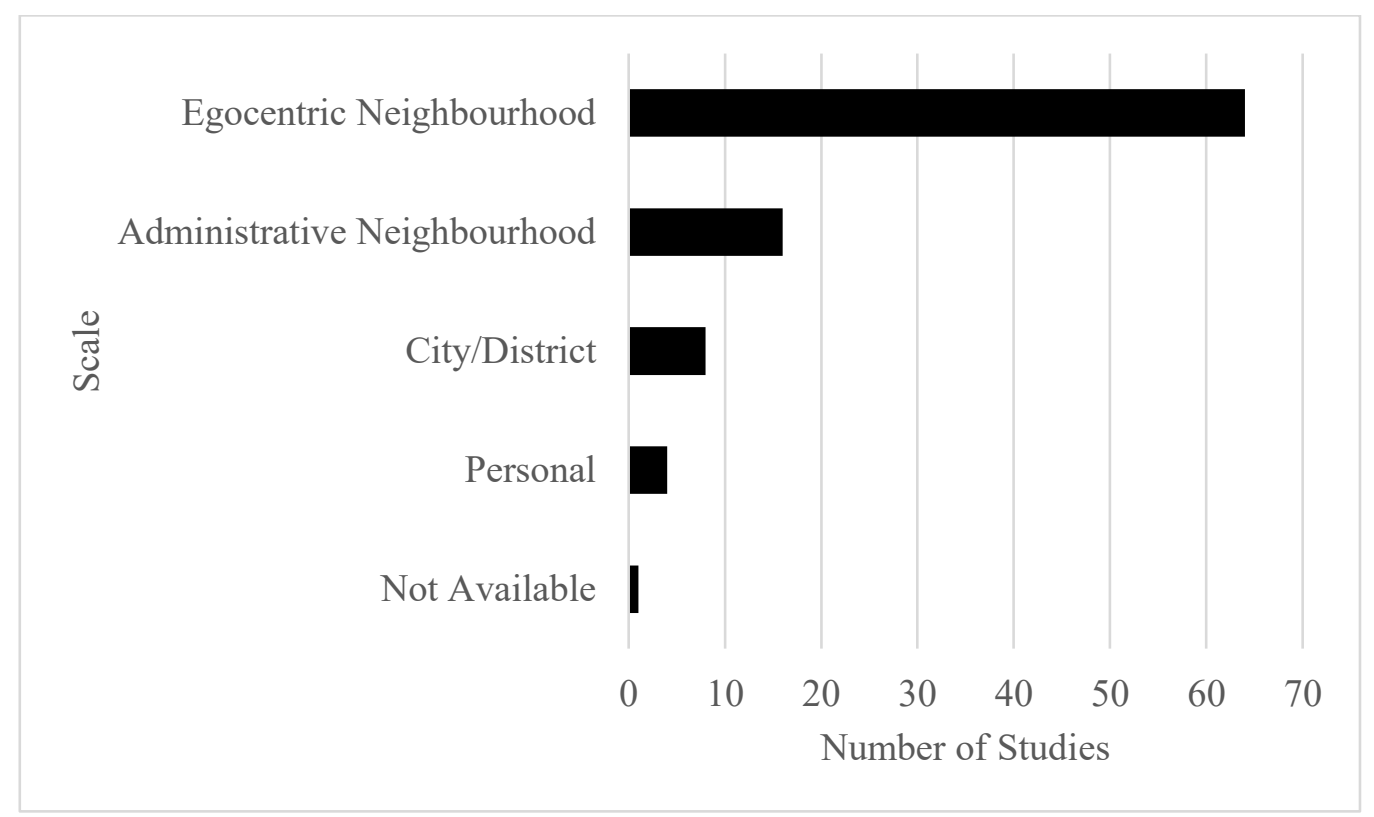

Figure 8: Commonly used spatial scales in greenspace and health association studies.

Neighbourhoods were defined in several different ways that can be broadly categorised as egocentric (e.g., a buffer around the home location) or allocentric (e.g., using a pre-defined administrative unit; see section 1.2.1). In the latter case, several studies used census units, such as census tracts (in the USA), Meshblock (in New Zealand) and Middle/Lower Super Output Areas (M/LSOA) (in England and Wales), which may be employed as a proxy for neighbourhood definition. The usage of such administrative definitions means that neighbourhood scale can vary substantially in size 
between different countries. For example, census tracts in the US represent an average population of 4000 (U.S. Census Bureau, n.d.), whereas, in England and Wales, an LSOA has an average population only of 1,614 (with 95\% of units having populations between 1,157 and 2,354 in 2011 (Office for National Statistics, 2012). This difference alone can influence the relative strength of the association. However, the most common representation of neighbourhood scale identified in this review $(n=64$, Figure 8) was an egocentric model determined using buffer distances from respondents' households (Figure 9a). This approach is particularly useful for studies seeking to establish relationships between individual residences and the local environment because it allows more refined representations of greenspace to be used (e.g., those derived from high spatial resolution remotely sensed imagery, see Figure 2).

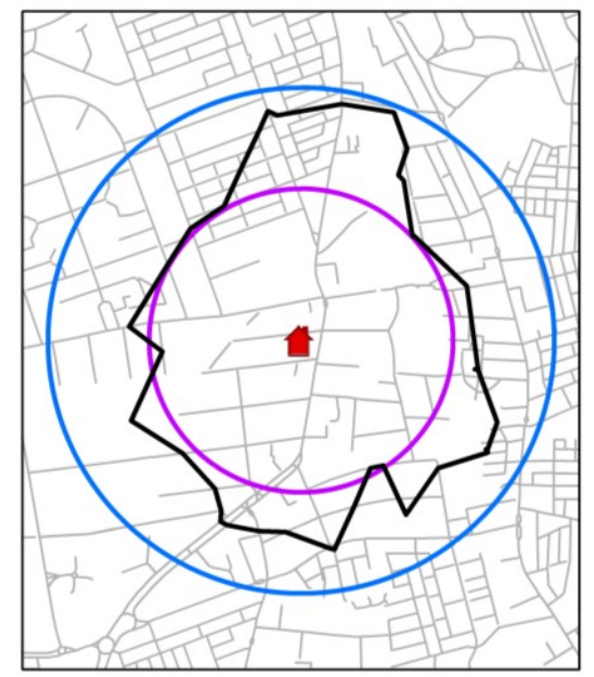

(a)

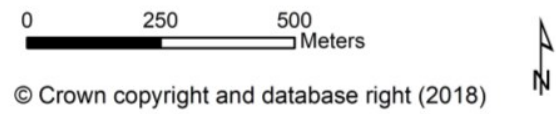

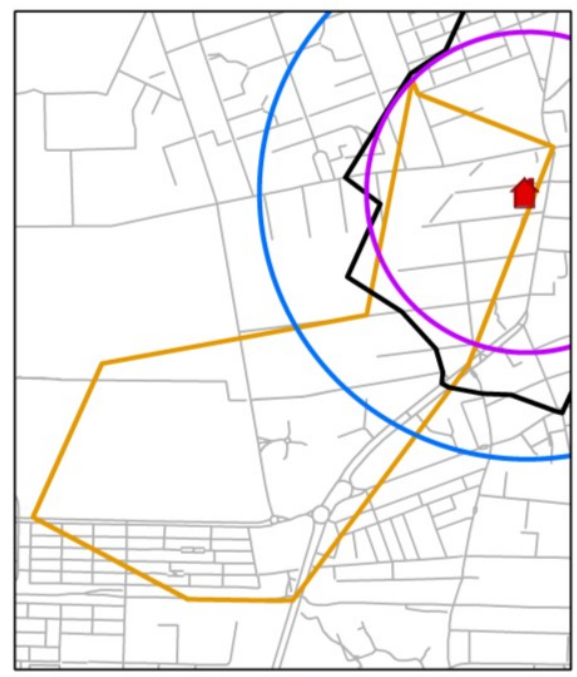

(b)

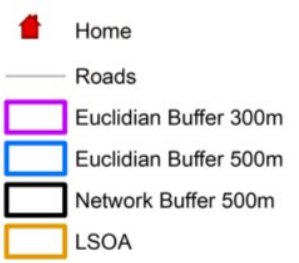

Figure 9: Differences in representations of the neighbourhood scale in health and greenspace studies. (a) Egocentric neighbourhood scale using Euclidian and network buffers. (b) Administrative neighbourhood unit (England and Wales Lower Super Output Area), comparing with the egocentric neighbourhood.

\subsubsection{Geocoding}

Geocoding is important as it defines the spatial reference point around which exposure areas are constructed, typically using either a fixed or network distance. Geocoding was widely used in the reviewed articles, with 65 of the 93 articles using geocoding to determine locations such as home or school. In addition, postcode and population-weighted neighbourhood centroid locations were also used as spatial points of reference to define the geographic exposure area $(n=7)$. The differences in positional accuracy associated with the different geocoding methods will have a bearing on the exposure 
metrics that result, but this is much less than the range of buffer sizes that are used to represent the AOI (Su et al., 2019; Browning and Lee, 2017).

\subsubsection{Buffer distance-based exposure area}

Buffer distances used in demarcating exposure areas included distances of $\leq 300,400,500$, and 800 meters (Figure 8). Articles using buffer distances of $\leq 300$ meters often cited the European Commission's recommendations that public open spaces should be within 300 meters of residences (Gascon et al., 2018; Van den Berg et al., 2017; Triguero-Mas et al., 2015; Gascon et al., 2015). Articles that used distances greater than 300 meters for their buffers often argued that buffer distances reflected a walking distance of five to 10 minutes and that individuals would be willing to walk this far to enjoy nature and exposure to greenspace (Stewart et al. 2018; Kim et al., 2016; Kaczynski et al., 2014; Cutts et al., 2009).

Varying study focuses (e.g., whether related to physical or mental health responses to greenspace) tended to produce different buffer distances. For example, with only one exception (Huynh et al., 2013), mental health studies were more likely to select buffer distances less than or equal to 300 meters. By contrast, studies focused on physical health often selected buffer distances between 300 and 1000 meters (Figure 10). The median value of the buffer distances used in mental health studies in this review was 400 meters, in contrast to the median value for physical health studies at 500 meters (Figure 10). Articles that focused upon both, applied median buffer distances of 500 meters in defining exposure areas. The majority of the studies used multiple buffer distances $(n=41)$ and tested sensitivity at different buffer distances (details in supplementary table 2S). The most frequent distance band used for the main analysis was 301-600m (Figure 10). Several authors tested the sensitivity of distances in excess of $1 \mathrm{~km}$, but these distances were not considered or reported as part of the main analyses in those studies (Dzhambov et al., 2018a; Triguero-Mas et al., 2017b; Nutsford et al., 2016).

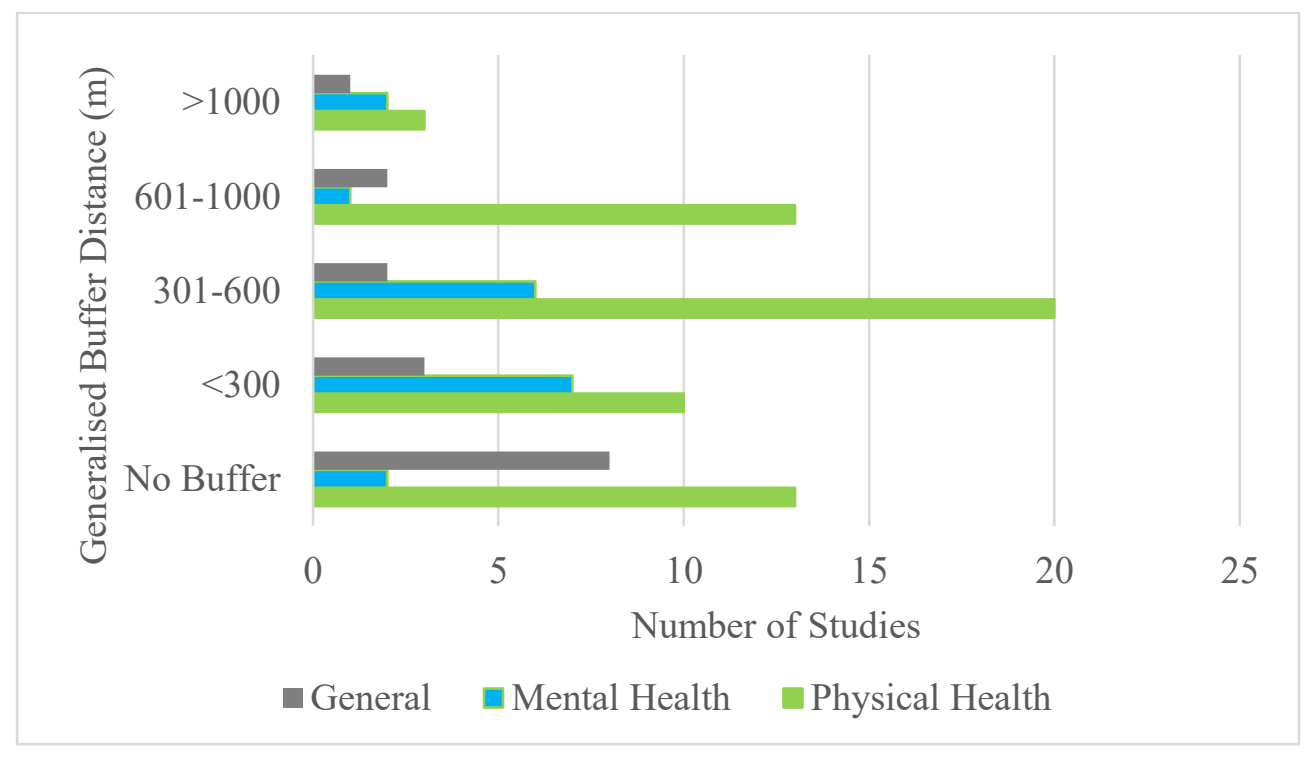

Figure 10: Commonly used generalised buffer distances by health outcome type. 
Buffering approaches (e.g., Euclidian or network distance) were also found to be key variables in defining both the exposure area and the scale for the reviewed articles. The majority of the 93 reviewed articles $(n=53)$ used a Euclidean approach. Several papers also used a network buffering approach $(n=20)$, and seven papers used both measures. The differences between these two buffering approaches are illustrated using an example in Figure 7a. It is clear from the example that the geographic exposure or scale of the studies, based on either a Euclidian or a network approach, is likely to result in a different exposure area for a study, despite the fact they may consider the same distance (e.g., 500 metres). Figure 7 a illustrates how a Euclidian (i.e., circular) buffer of 500 metres provided an exposure area of $0.785 \mathrm{~km}^{2}$. For the same distance, a network buffer approach provided an exposure area of 0.411 $\mathrm{km}^{2}$.

The reasons for selecting either approach varied. The papers that used a Euclidean approach to define the exposure area or scale argued that it would be challenging to be certain about the personal trajectories of an individual's visit to the nearest greenspace as there would likely be informal routes within a neighbourhood that did not appear in records of the formal road network (Cutts et al., 2009). For example, OpenStreetMap has more informal routes than the Ordnance Survey (OS) street network dataset, meaning that using the OS network data in defining a network-based exposure area might omit key informal routes and not provide a true reflection of the exposure area. By contrast, the papers that used network distances argued that a person cannot travel as the crow flies but rather must follow the street network in order to reach greenspace. People also use different modes to travel (e.g., walking, driving, cycling), and different modes can require designated routes (Kaczynski et al., 2014; Mukherjee et al., 2017). Once again, the selection of the approach was often linked to the focus of the study (Browning and Lee, 2017). For example, Dadvand et al. (2014) argued that the network approach is more appropriate for physical health consideration. If accessibility is a key issue, using network distance is more logical, but if the availability of greenspace and its impact on heat mitigation or air pollution are considered, then the use of Euclidian distance is more representative.

\subsection{Commonly used spatial data when representing greenspaces/greenness}

Within the exposure area, the representation of greenspace or greenness can be broadly categorised into two different types based on the use of spatial data: satellite-derived indices and land use and land cover-derived (LULC) metrics (Markevych et al., 2017; Van den Berg et al., 2015). The latter included analysis based on pre-existing national datasets or data derived from land cover classification. Tree canopy measurements (e.g., area and density) were applied in some studies, which often used the LiDAR dataset do detect canopy area (Reid et al., 2017; Ulmer et al., 2016).

Among the 93 papers reviewed, most used LULC metrics $(n=47)$. Indices such as the Normalised Difference Vegetation Index (NDVI), the Soil-Adjusted Vegetation Index [SAVI], and the Enhanced Vegetation Index [EVI]) were the second-most commonly used approaches to measuring 
greenness within exposure areas $(n=19)$. A combination of LULC and NDVI $(n=12)$; NDVI and tree canopy $(n=5)$; and LULC and tree canopy $(n=2)$ was also applied to measure greenness and the presence of greenspace. Additionally, three studies used Google Street View (GSV) images, applying computer vision or image analysis techniques (Villeneuve et al., 2018; Li and Ghosh, 2018; Nguyen et al., 2018). Nutsford et al. (2016) utilised digital elevation model-based viewshed analysis to represent greenness. As a whole, we observed diversity of data types, metrics, and sources used in the reviewed articles, resulting in varying spatial and temporal resolutions.

\subsection{Spatially explicit methods of exposure assessment}

\subsubsection{Greenspace/greenness availability}

The most widely used spatially explicit measures of greenspace exposure were based on estimated greenspace or greenness availability within specific AOIs $(n=75)$, mostly at the neighbourhood scale. Availability was quantified differently based on the types of spatial data used. Availability was primarily quantified using the mean NDVI value $(n=25)$; the percentage cover of the AOI $(n=23)$; area $(n=7)$; or both area and the number of green spaces $(n=8)$.

In general, out of the 75 studies that considered availability exposure, 62 explicitly found significant positive associations between availability and health indicators. However, the strength of the associations varied according to different spatial data types, quantification methods (e.g., percentage, NDVI value, and numbers of trees), and scales used for the spatial data (Dzhambov et al., 2018c; Wood et al., 2017; Cusack et al., 2017; McEachan et al., 2015; Dadvand et al., 2014). In some studies, however, associations between availability exposure and health indicators were found to be insignificant (Glazer et al. 2018; Van den Berg et al., 2017; Triguero-Mas et al., 2017a), or the analyses suggested negative associations ( $n=3)$. Abelt and McLafferty (2017) found an insignificant association between NDVI value and pre-term birth and birth weight, but higher numbers of street trees were found to have a significant inverse association with pre-term birth weight within different buffer zones. Although this may be partly linked to representation, the finding also points to the potential importance of different exposure types. Dzhambov et al. (2018c) observed significant positive associations between vegetation availability within a $300 \mathrm{~m}$ buffer but found an insignificant association for the availability of blue space within the same AOI when associated with mental health. Additionally, Dadvand et al. (2014) observed significant associations with available NDVI and low BMI for buffers below 500 meters, but the same associations became insignificant at buffer distances above 500 meters. This evidence indicates that different spatial approaches of assessing availability exposure (e.g., in terms of buffer distances, scales, data) influence the strength and significance of associations with health indicators. 


\subsubsection{Accessibility to and from greenspace}

Accessibility to greenspace is the second most widely used measure of exposure in health studies. In this review, several studies $(n=48)$ used measures of accessibility to represent proximity to greenspace. In quantifying accessibility based on proximity, fixed distance in terms of Euclidian buffers ( $n=18)$, shortest or nearest distance using both Euclidian and network methods $(n=24)$, and both fixed and shortest measures $(n=6)$ were applied in the articles. The review suggested that different accessibility measures provided different results in terms of health.

For example, Cutts et al. (2009) found access to local parks within a fixed distance of 400m was significantly associated with health indicators, while Pietile et al. (2015) found that increasing the distance from the greenspace beyond $1000 \mathrm{~m}$ was associated with negative health outcomes. Mukherjee et al. (2017) found a significant positive association between the shortest distance to the nearest greenspace and a reduction in depression. However, Michael et al. (2014) found no significant association between the shortest distance to a park (e.g., increasing accessibility) and BMI reduction. Jonker et al. (2014) observed a significant association between average shortest distance to greenspace and life expectancy. These examples highlight the fact that varying fixed distances to and from greenspace might also influence the results in relation to different aspects of health (e.g., physical or mental health).

It should be noted that accessibility was often used in combination with availability to assess the influence of greenspace. Thus, it cannot be confirmed that the varying health outcomes were linked exclusively to differences in accessibility (Cusack et al., 2017; Laatikainen et al., 2017; Sarkar et al., 2013). Using different methods to define and measure accessibility might influence the level of significance of the association between greenspace and health indicators.

\subsubsection{Visibility of greenspace}

An alternative measure of exposure assessment involves calculating the visibility of greenspace or greenness from individual and common points of view (POVs). In this review, seven papers used visibility as a measure of exposure to greenspace or greenness, and with only one exception (van Dillen et al., 2011), all of them were recently published (i.e., 2016-2018). Out of the seven articles, six found a significant positive association between greenspace/greenness visibility and health outcomes (Nguyen et al., 2018; Taylor et al., 2018; Villeneuve et al., 2018; Li and Ghosh, 2018; Nutsford et al., 2016; van Dillen et al., 2011). The seventh article found a positive but not significant association between visibility and walking frequency (Zhai and Baran, 2016). The visibility measures used in these articles included the vertical visibility index (VVI) using a digital elevation model (Nutsford et al., 2016); Google Street View panoramic image analysis using a convolutional neural network (Nguyen et al., 2018; Li and Ghosh, 2018; Villeneuve et al., 2018); and lateral visibility based upon graph analysis (Zhai and Baran, 2016). Nguyen et al. (2018) used zip codes to define the exposure area assessed for visibility level, and 
Nutsford et al. (2016) used buffer distances (e.g., more than three km). In contrast, Zhai and Baran (2016) did not use any zone or defined exposure boundary, instead, evaluating lateral visibility along the pathways (i.e., how much people can see surroundings when walking) based on the space-syntax method, making visibility a function of interruptions of lateral sightlines due to the presence of greenness.

The use of different GIS methods made it difficult to compare the effects of visibility on health and health-related behaviour. However, evaluating the association between the visibility of greenness and health indicators is merited, given its link to perceptions and other factors that influence health (Villeneuve et al., 2018; Ward Thompson et al., 2010; Kaplan, 2001).

\subsection{Built environment factors}

In addition to exposure, the wider use of geospatial methods in the surveyed articles was observed in the determination of environmental characteristics and spatial association analysis. Built environment factors were often used as mediators or moderators of greenspace-health associations $(n=$ 40). We identified 17 unique built environment factors considered in the reviewed articles. However, the most commonly used factors included walkability (Christian et al., 2017; Ulmer et al., 2016; Su et al., 2016; Yin, 2013; Lovasi et al., 2013; Cutts et al., 2009); urbanicity/degree of urbanisation (Egorov et al., 2017; Sarkar et al., 2018; Sarkar, 2017; Markevych et al., 2014b; Wolch et al., 2011); road density or connectivity (Wu and Jackson, 2017; Su et al., 2016; Burgoine et al., 2015; Coombes et al., 2010); and land use mix or diversity (Zandieh et al., 2017; Sarkar et al., 2013). Interesting factors such as home yard area availability (Christian et al., 2017), community design (Almanza et al., 2012), and imperviousness (Wolch et al., 2011) were also used in examinations of greenspace and health. Many of the built environment factors tended to show significant associations with health indicators. For example, greater diversity in land uses encouraged walking. However, others showed negative associations (e.g., higher road density induced more traffic and reduced walkability; Zandieh et al., 2017; Lovasi et al., 2013).

A few studies also applied spatially explicit environmental factors such as air pollution and noise pollution as mediators $(n=18)$. Some studies found air and noise pollution significantly mediated the health and greenspace relationship (Agay-Shay et al. 2019; Gascon et al., 2018; Vienneau et al., 2017; Demoury et al., 2017; James et al., 2016; Su et al., 2016). By contrast, Dzhambov et al. (2018c) indicated that $\mathrm{NO}_{2}$ pollution had an insignificant mediating effect. Despite the fact that greenspace is usually a significant mediator/moderator, several studies found that the proactive effect of greenspace as a mediator can be quite low $(<10 \%)$ in terms of health outcomes (Vienneau et al., 2017; Gascon et al., 2018; James et al., 2016). It is possible that where there was no considerable effect of greenspace on air quality or where the effect was only marginal, the concentrations of pollutants exceeded the moderating ability of greenspace (see Janhäll, 2015; Vos et al., 2013; Eisenman et al., 2019). 


\subsection{Spatially explicit association analysis and spatial autocorrelation}

Geospatial methods were also directly used in several studies to model spatial associations between greenspace and health outcomes as an alternative to the common approach of analysing these associations using logistic, linear, and Poisson regression and survival modelling. Wu and Jackson (2017) and Su et al. (2016) applied spatial regression and found a significant association between health and greenspace, particularly in terms of land use types (e.g., parks, urban amenity spaces). Sarkar et al. (2013), Yin (2013), Koohsari et al. (2013), and Zhai and Baran (2016) applied space-syntax methods, using the DepthMap software to determine accessibility, configurations of paths within parks, walkability, and impact on walking behaviour. This approach accounted for the built environment, allowed the determination of overall accessibility and visibility, and provided greater detail concerning greenspace use. It accounted for how much people walked, indicated the areas that were perceived to be more usable, and identified what attributes of an area correlated to more people walking (Zhai and Baran, 2016). In addition to deterministic modelling, Yin (2013) applied an agent-based model (ABM) when predicting walkability conditions based on a variety of greenspace and built environment characteristics. Yin's research demonstrated that spatially explicit ABM models could successfully predict walking behaviour based on greenspace and built environment characteristics. As a result, Yin's simulation models can aid in understanding the influence of built environment factors in determining levels of walkability and related exposure in the context of various urban environmental contexts.

Greenspace, health, and related socio-economic data often show spatial autocorrelation. Therefore, statistical associations may also show geographical bias and result in a violation of the assumption of independence of residuals and Type-I error estimation (Helbich et al., 2018; Wu et al., 2018; Hystad et al., 2014; Waller and Gotway, 2004; Diniz-Filho et al., 2003). Among the reviewed articles, nine studies considered spatial autocorrelation. Among these studies, four found the presence of spatial autocorrelation (Helbich et al., 2018, Browning and Rigolon, 2018; Wu et al., 2018; Almanza et al., 2012); three studies reported no significant presence of spatial autocorrelation ( $\mathrm{Li}$ and Ghosh, 2018; Egorov et al., 2017; Hystad et al., 2014); and two studies considered the presence of spatial autocorrelation without testing or adjusted the models to minimise autocorrelation errors (Yeager et al., 2018; Jonker et al., 2014). These studies applied several approaches to adjusted spatial autocorrelation such as smoothing using kernel density (Almanza et al., 2012); spatial moving average (Browning and Rigolon, 2018); and Bayesian spatial models along with traditional regression models (Helbich et al., 2018; Wu et al., 2018). Results of these models indicated that spatial autocorrelation could influence the association between greenspace and health, and therefore, it should be considered carefully (also Waller and Gotway, 2004). 


\section{Discussion}

\subsection{Spatial scale and geographic exposure area}

We found substantial variation in the selection of study scale and corresponding geographic exposure areas (e.g., AOI). Other reviews have reported similar findings with respect to AOI sections (Nordbø et al., 2018; Jia et al., 2017). The present review determined that studies in health-greenspace relationships mostly utilized personal, neighbourhood, and city/district scales to set the spatial contexts of their research. Neighbourhood was the most commonly used scale, but researchers utilized a wide variety of definitions when conceptualising the geographic scale and area of the neighbourhood. The egocentric definition of neighbourhood based on fixed or network distances around geocoded addresses was popular among recent researchers (Nordbø et al., 2018) as it provided consistency in the definition of the geographic scale and area of neighbourhood when fixed-distance methods were applied (Chaix et al., 2013). In contrast to these egocentric models, allocentric approaches (e.g., the use of an administrative zone as a proxy for neighbourhood definitions) are more likely to produce a biased estimation of the exposure area based on the location of the home within the defined administrative boundary (Chaix et al., 2013).

In addition to variations when defining neighbourhoods, the potential presence of scale effects related to MAUP provide additional variations in spatial scales and corresponding geographic exposure areas that are likely to influence identified associations between greenspace and health (Su et al., 2019). These circumstances imply that a larger scale with greater spatial aggregation may present a more significant association (Houston, 2014; Mitra and Buliung, 2012; Dark and Bram, 2007). The reviewed articles indicated possible support for the presence of scale effects. Studies that used an egocentric neighbourhood and found a significant association between health and greenspace ( $n=51)$ used mostly larger buffer distances to define their neighbourhood scale.

Studies using larger district/city scales all found a positive association between greenspace and health. By contrast, similar studies that considered egocentric neighbourhoods and personal scales $(n=$ 5) found insignificant associations. The differences between these two groups of studies (larger vs. smaller scale) indicated the importance of the definition of the spatial scale. Despite the fact that such differences in buffers were not statistically significant (at the $p>0.05$ level), possibly due to smaller sample sizes and larger standard deviations of buffer distances, such evidence suggests that the potential presence of a scale effect when aggregating data at different buffer distances. The larger-scale studies mostly found evidence of a significant association between health and greenspace; however, the effect size or strength of association became smaller or inconsistent, which was also found other studies ( $\mathrm{Su}$ et al., 2019, Helbich, 2019; Houston, 2014; Wolch et al., 2011).

We found that the exposure areas used in most of the studies were determined by the spatial unit of analysis, particularly for studies using an egocentric neighbourhood approach. The few studies 
that utilized different definitions of scale also utilized different distance values and approaches (e.g., Euclidian or network). Buffer distances used to measure availability and accessibility should be subjected to sensitivity analysis when determining exposure levels (Reid et al., 2018; Dzhambov et al., 2018a; Dzhambov et al., 2018b; Dadvand et al., 2014). Using only a single buffer or multiple buffers without considering overlapping zones limits or removes the possibility of understanding at which spatial extent different exposures provide better results (Browning and Lee, 2017).

In this review, we found no provision made in any of the studies reviewed for the utilisation of overlapping zones of buffers. There was also no indication provided in the studies as to whether the authors used generalised or non-generalised buffers (Forsyth, 2007). Instead, aggregated buffer zones had been considered for the exposure area in most of the studies. It can be argued that often an aggregation of exposures to a collection of buffers might produce significant results, but this is again possibly due to the presence of the scale or zonal effect of the MAUP (Su et al., 2019; Kwan, 2018; Houston, 2014; Dark and Bram, 2007). Usually, the selections of buffer distances were arbitrary due to a lack of empirical guidance relating to the appropriate distance for buffers (Nordbø et al., 2018; Browning and Lee, 2017). Analysis should be conducted to identify the buffer distances appropriate for different metrics of greenspaces (e.g., NDVI, Leaf area index, LULC), considering the influence of scale effects and MAUP.

The use of discrete buffer zones also implies that the relative importance of greenspace availability, accessibility, or visibility is uniform across space. However, this may not be the case and instead the influence of greenspace or greenness might be assumed to exhibit distance decay over space within specific spheres of influence (Egorov et al., 2017). For example, a drop-off in influence might be seen due to the relative importance of the immediate proximity of peoples' homes for exposure to environmental hazards, as indicators of the areas experienced most frequently, whether for passive or active uses, and/or as a marker of what gives a place a sense of belonging (Xie et al., 2018). This sort of spatial relationship might lead itself to representation through the use of kernels, weighted functions or fuzzy logic (Malczewski, 2006; Boroushaki and Malczewski, 2008; Labib, 2019). Although there are examples of the use of distance decays (Egorov et al., 2017; Requia et al., 2016) there is yet little evidence of the use of such approaches in the literature.

\subsection{Improved data to measure and represent greenspace/greenness}

A range of land use/land cover (LULC) and satellite-based greenspace measurement methods was used in the papers under review for objectively quantifying and representing greenspace for the purpose of testing connections with human health. However, the LULC databases often adopted in the reviewed articles are coarse in spatial resolution. For example, the CORINE, TIGER, Urban Atlas 2006 (European Environment Agency), and Top10NL datasets have a spatial scale of 1:100,000, indicating large aggregations in terms of representing natural features on maps. Due to potential MAUP, these 
coarse resolution datasets with greater aggregation and different exposure areas (e.g., based on buffer zones) are likely to provide inconsistent associations between greenspace and health, especially a higher likelihood of correlations with higher degrees of aggregation ( $\mathrm{Su}$ et al., 2019; Reid et al., 2018; Houston, 2014).

Furthermore, neither CORINE nor Urban Atlas 2006 includes green areas of less than 25 hectares (ha) (Dennis et al., 2018; Triguero-Mas et al., 2015). Therefore, national, regional, or even local LULC datasets might not register small greenspaces such as pocket parks due to the generalisation and aggregation process in GIS (Reid et al., 2018; Houston, 2014; Dadvand et al., 2012). Similar problems may occur with the use of moderate or low-resolution optical satellite images such as Landsat (spatial resolution 30 meters) or MODIS (spatial resolution 250 meters). For these data sources, green or blue areas less than 900 square meters in Landsat $(0.09 \mathrm{ha})$, or 62,500 square metres for MODIS (6.25 ha) would likely be misclassified when using NDVI or other indices (e.g., SAVI or EVI; de Keijzer et al., 2019; Markevych et al., 2017; Wilker et al., 2014). Thus, with a larger cell size (moderate or low resolution), smaller areas of the natural world are inappropriately illustrated in the images collected or processed from these satellite imaging systems (Xu et al., 2017; Su et al., 2019). These issues may help explain the different associations found when using alternative satellite imagery sources. For example, Reid et al. (2018) observed insignificant associations with individual health outcomes when using MODIS greenness data but found significant associations for the same health outcomes with higher resolution data (i.e., Landsat).

The low spatial resolution of the data and corresponding omissions of smaller greenspaces are critical difficulties with much of the data available from satellite imagery (Dadvand et al., 2012). Wood et al. (2017) demonstrated that smaller pocket parks, not properly identified using many satellite imaging systems, have significant associations with mental health improvements. Additionally, Jansen et al. (2017) found that medium-size parks ( 7 to $27 \mathrm{ha}$ ) positively induce moderate and vigorous physical activities. Hooper et al. (2018) used LULC data at a 1:2,000 scale (compared to a 1:100,000 scale) and found that small greenspaces of 0.4 to 1 ha were more common and accessible to residents within 400 meters, compared to large scale greenspace of more than 5ha. This finding indicates that the spatial resolution of satellite imagery is crucial to properly measure the level of exposure for different pathways of exposure benefits (e.g., availability, accessibility).

Considering the issues identified with low-resolution satellite imagery in the context of smaller urban greenspace identification while using the LULC database or satellite images, higher spatial resolution data should be given greater emphasis (see also Su et al., 2019; Reid et al., 2018; Labib and Harris, 2018; Markevych et al., 2017). For example, in the UK, the newly released 2017 OS Mastermap greenspace layer provides 18 categories of greenspace, with a very fine resolution of 1:2,500. Dennis et al. (2018) have pointed out that with the availability of such detail, LULC data, along with highresolution satellite images (i.e., Sentinel-2), considerably improves greenspace detection and 
measurement compared with low-resolution Urban Atlas data. Future studies intending to use LULC data should seek more detailed LULC data, along with high spatial resolution satellite images for feature extraction (Su et al., 2019; Reid et al., 2018). Examples of systems that can provide such data include Sentinel-2 at $10 \mathrm{~m}$ spatial resolution (Labib and Harris, 2018), LiDAR-based systems (Klingberg et al., 2017), and high-resolution EnviroAtlas community scale land use data at a 1-m spatial resolution (Egorov et al., 2017). For cross-checking LULC, studies can also use very high-resolution Google Earth images and commercial satellite images such as Geo-Eye or Worldview (Su et al., 2019; Labib and Harris, 2018; Mukherjee et al., 2017).

Another critical aspect of representing greenspace or greenness is the differences between 2D and 3D representation using spatial data. In this review, we found most of the datasets used when representing greenness or greenspace (e.g., LULC, NDVI, and Tree Canopy) are seen from a bird's eye view and thus, are 2D in their representations (Jiang et al., 2017). Except for geo-tagged Google Street View images, none of the greenness data sources provide eye-level views of greenspace or greenness (Helbich et al., 2019; Nguyen et al., 2018; Li and Gosh, 2018). Additionally, the potential use of methods to represent greenspace in 3D and assess what can be observed at a particular viewpoint remain less well explored (Nutsford et al., 2016; Dempsey et al., 2018; Villeneuve et al., 2018).

Although not the only pathway through which human health is influenced, some have suggested that greenspace observation alone can be important (Kaplan, 2001; Kaplan and Kaplan, 1989; Ratti, 2004; Van den Bosch and Bird, 2018; Zhai and Baran, 2016). Despite Rhew et al. (2011) validating the NDVI-based measurement in reference to the eye-level measurement of greenness by expert review, a more recent study by Jiang et al. (2017) suggests that optical remote sensing images may not always adequately represent the actual 'greenness' observed at eye level. Gehl (2013) supports this observation, noting that, along a straight line at eye level, people observe around 50 to 55 degrees upward and 70 to 80 degrees downward and often fail to witness objects that are outside this viewing range. Using $2 \mathrm{D}$ data, such as LUCL or NDVI, to measure greenspace exposure in terms of availability or accessibility may not be adequate to indicate the overall impact of greenspace on health. 3D data (e.g., GSV, digital elevation model) within the viewing angle available at eye level should be given proper attention to understand the visibility exposure and greenness perception of people and how these measures relate with health indicators (Helbich et al., 2019; Li and Ghosh, 2018; Nutsford et al., 2016).

\subsection{Greenspace exposure assessments}

We found that availability and accessibility, as measures of greenspace exposure, dominated the papers in the review and largely supported the positive association between greenspace and health (Halonen et al., 2017; De Keijzer et al., 2019; Laatikainen et al., 2017; Dadvand et al., 2017; McMorris et al., 2015; Tamosiunas et al., 2014; Mytton et al., 2012). However, these measures are limited by their failure to account for visibility, perceived greenness access, and contact with nature in terms of duration. 
There are also limits in the way that these pathways are conceptualised and represented spatially, something which could be improved by using more sophisticated analytical approaches. Furthermore, these exposures are also unable to capture seasonality and the temporal dimensions of greenspace, along with their quality (Dzhambov et al., 2018a, Van den Berg et al., 2017). Different data types representing greenspace or greenness may produce variations in the level of availability or accessibility exposure. As illustrated in Figure 2, different types of greenspace-related data and metrics have different levels of availability exposures. Similar findings were observed in Abelt and McLafferty (2017) and Gascon et al. (2018).

We observed that availability exposure assessments and their relationships with health data varied based on the type of greenspace metrics (e.g., NDVI vs tree canopy; NDVI vs. EVI); the resolution of spatial data (MODIS vs. Landsat); the buffer distances used to set the exposure area (e.g., $400 \mathrm{~m}$ vs. $1600 \mathrm{~m}$ ); and the spatial scale of analysis and health indicators under consideration (e.g., BMI, skin cancer, mortality, depression; Dzhambov et al., 2018c; de Keijzer et al., 2019; Andrusaityte et al., 2016; Dadvand et al., 2014; Potestio et al., 2009) (more in section 3.6.1). Therefore, careful attention should be given in terms of the selection of scale of analysis, buffer distances, and type and resolution of data while assessing the availability exposure. Systematic investigation would be required to understand appropriate buffer distances for certain greenspace data (e.g., distance appropriate for different satellite images, or NDVI or Leaf area index).

In addition to availability exposure, accessibility exposure is also limited by how accessibility is measured if only the shortest distance to the nearest greenspace is considered rather than other available greenspace within the exposure area. Furthermore, issues remain related to which greenspace should be considered for accessibility (e.g., public parks, school grounds, or sports facilities). All these might result in under or overestimating availability and accessibility exposure. We identified inconsistency in associations depending on different methods used in measuring accessibility (e.g., shortest distance vs. fixed distance; 300 metres vs. 5000 metres) and in choosing health indicators (e.g., physical activities, mental health; Cusack et al., 2017; Laatikainen et al., 2017; Klompmaker et al., 2018; Vogt et al., 2015; Koohsari et al., 2013) (more in section 3.6.2). These differences highlight the potential impact of spatial methodological decisions when conducting accessibility assessments. Further investigation is required when selecting a distance measurement approach for accessibility and combining multiple accessibility assessment approaches. To ensure the consistency and comparability of results based on available data, all the possible types of availability and accessibility measurements that are available should be considered according to the likely cumulative effects of exposures on the outcome of interest.

The review indicated there was limited use of visibility exposure assessment in current studies (also Houlden et al., 2018), despite the fact that visibility plays a vital role in making people comfortable in outdoor environments and encourages engagement with nature, thus offering health benefits (Ward 
Thompson et al., 2010; Kaplan, 2001; Ulrich et al., 1991) (more in section 3.6.3). Most of the current studies used availability and accessibility while ignoring the variations in greenspace/greenness exposure due to the varying visibility attributed to individuals' dynamic movements in space and time (Jiang et al., 2017; Nguyen et al., 2018). As visibility is a key indicator of greenspace use and related feelings, visibility exposure should be incorporated into future assessments through the use of tools and methods such as Google Street View (Helbich et al., 2019; Larkin and Hystad, 2018; Li and Ghosh, 2018); SPOTLIGHT protocol for using Google Street View images (Bethlehem et al., 2014); and a viewshed-based 3D GIS approach (Nutsford et al., 2016).

It should be noted that availability, accessibility, and visibility exposure are usually static in their estimation process as they do not take account of the frequency of visits to greenspace or the duration of exposure. Frequency and duration are important exposure indicators that are largely missing in the majority of the studies we reviewed. Few studies considered the temporal aspect of exposure (Zhang et al. 2018; Triguero-Mas et al., 2017a; Van den Berg et al., 2017; White et al., 2017; Tamosiunas et al., 2014; Matisziw et al., 2016). Van den Berg et al. (2017) considered the time spent in greenspace (co-location) to be a mediator variable and used a survey-based method to determine such exposure. Triguero-Mas et al. (2017a) also used the length of time in "contact with greenspace" as a measure of exposure.

Frumkin et al. (2017) argued that even if individuals living in the same neighbourhood have similar exposure in terms of availability, accessibility, and visibility, each individual will experience exposure differently based on visit frequency and duration. Thus, time as an attribute of greenspace exposure is vital because depending on the temporal aspect, the exposure level can be significantly modified, which can, in turn, influence the strength of association between greenspace and health (Bratman et al., 2019; Dzhambov et al., 2018a; Triguero-Mas et al., 2017a; Bratman et al., 2015). Therefore, only considering fixed geographic exposure areas may fail to capture the dynamics of greenspace exposure when moving from one place to another for different activities (Helbich, 2018; Zhang et al. 2018). A focus on fixed exposure also cannot take account of the direct benefits of greenspace that persist over time just by being in close proximity to greenspaces (e.g., the cooling effects of parks at different times of the day and night; Coppel and Wustemann, 2017; Kaczynski et al., 2014; Beyer et al., 2014). Availability, accessibility, and visibility may not be sufficient measures of exposure or of the benefits obtained from greenspace for health. Combined spatio-temporal components of exposure should ideally be included in exposure measurements to better understand the effects of greenspace on health along different pathways (Dadvand et al., 2019; Zhang et al. 2018; Helbich, 2019; Helbich, 2018).

The review paper indicated that spatially explicit exposure measurements (mostly availability and accessibility) tend to represent the quantity of greenspace/greenness, rather than the quality or attractiveness of greenspace. Spatial data are often unable to represent the quality of an individual's 
perceptions (Leslie et al., 2010), but they can provide the basis for the assessment of landscape diversity. Hence, researchers often use quantity as a surrogate representation of the quality or attractiveness of greenspace (Wheeler et al., 2015; Cutts et al., 2009). The combination of both quantity-based exposures with quality-based exposures might provide a more robust estimation of greenspace (Jonker et al., 2014; Van Dillen et al., 2012). For this reason, Rugel et al. (2017) proposed a natural space index of exposures that incorporates both the quantity and quality of exposures.

Ultimately, developing and testing multi-scale composite greenspace exposure assessment methods should be given the greatest priority, due to their potential to address different types of exposures comprehensively. From the perspective of the 93 studies considered as a whole, it would appear that combining availability, accessibility, visibility (at eye level), time duration, and personal perception (Schipperijn et al., 2017; Cleary et al., 2019) into a dynamic composite that also takes relevant human traits into account could create a comprehensive composite measure of all the factors that might influence the level of exposure.

\subsection{Spatially explicit methods for health indicator measurements}

Apart from scale setting, exposure area determination, and exposure assessment, innovation in geospatial technologies has enabled researchers to use spatial technologies such as GPS as part of an armoury of methods to assess health outcomes associated with physical activities. Active transportation is now a common concept in research into health geographies due to the robustness in capturing and representing the relationship between the surrounding environment and health conditions (TrigueroMas et al., 2017a; Burgoine et al., 2015; Mitra and Buliung, 2012; Zenk et al., 2011). In this review, we found GPS trackers, accelerometers, and pedometers were used as devices that could provide personalised and dynamic objective data on activities that could act as direct or surrogate health

indicators (Zhang et al. 2018). The effectiveness of these devices is reflected in the popularity they have gained among researchers and authors of current health-related articles, as other studies have noted (Rosenberg, 2017; Huck et al., 2017).

Measuring the minutiae of human movement and human activities has several current limitations, including data intensity requirements, which means that this method is often applied for only a few days to collect observations from limited numbers of individuals (Ward et al., 2017; Burgoine et al., 2015; Almanza et al., 2012). Such small samples pose problems for generalising results in larger populations (Rosenberg, 2017). Nevertheless, using GPS-based geotagged data to record the physical movements of individuals using fitness tracker apps (e.g., Fitbit, Google-fit) has the potential to produce large volumes of objectively measured data that represents health through proxy indicators (e.g., the number of steps taken in a day or heart rate). Such data sources could help researchers to address the limitations arising from small sample sizes and insufficient data from which to generalise at a population scale (Triguero-Mas et al., 2017b; Schipperijn et al., 2017; Mukherjee et al., 2017; Musa 
et al., 2013). However, GPS-based methods often generate different biases from the sample, such as selective daily mobility bias, walking behaviour or physical activity behavioural alteration bias when sample or observation data are included in the process (Burgoine et al., 2015; Chaix et al., 2013). Furthermore, GPS-based studies often face issues with GPS inaccuracy, missing data, misclassification of activities (e.g., walking, running), or the intrusion of noise from other digital devices operating on the same frequencies as Wi-Fi and Bluetooth devices (Helbich, 2018; Ueberham and Schlink, 2018; Chaix et al., 2013). Nonetheless, the application of GPS-based dynamic exposure assessments and health outcome measurements do have great potential with the advent of smartphones and the wider availability of cellular and wireless internet access.

\subsection{Need for spatial association analysis}

The analysis of associations between health outcomes and greenspace variables is mainly conducted using non-spatial statistical models (e.g., linear, logistic, Poisson). Tests of spatial autocorrelation are principally used to assess spatial correlation in regression residuals, and there is little explicit exploration of local regression or consideration of other spatial phenomena like MAUP (Fotheringham, and Rogerson, 2008; Waller and Gotway, 2004). Usually, all spatial data inherently possess spatial autocorrelation, and remote sensing data of natural objects even show stronger positive spatial autocorrelation (Griffith and Chun, 2016; Zhang et al., 2009). Applying non-spatial models while using such correlated observations raises two major issues; (a) the presence of autocorrelation violates the assumption of independence of observations, and correlated observations contain less statistical information, reducing the effective sample size; (b) positive autocorrelation also results in variance inflation due to multicollinearity (Griffith and Chun, 2016; Bivand et al., 2008; Waller and Gotway, 2004). Both of these issues can affect non-spatial statistical models so that they produce more apparently significant results than the data actually justifies, often leading to the incorrect rejection of a null hypothesis (Type-1 error; Griffith 2013; Waller and Gotway, 2004; Dale and Fortin, 2002). Thus, associations analysed without considering spatial autocorrelation might not be robust, accurate, and meaningful. For greenspace and health studies, we observed a lack of testing and reporting of spatial autocorrelation among the existing studies. However, in studies where authors adjusted their models for spatial autocorrelation, significant positive statistical associations between greenspace and health were still found (e.g., Browning and Rigolon, 2018; Helbich et al., 2018; Almanza et al., 2012).

Another issue that requires more examination is the potential effect of data aggregation and the use of varying buffer distances. Aggregation of spatial data is likely to produce MAUP and may also introduce higher correlations among the observations (Fotheringham and Rogerson, 2008; Bivand et al., 2008; Waller and Gotway, 2004), particularly for satellite image driven greenspace exposure metrics (Su et al., 2019; Reid et al., 2018). In order to test the presence of spatial autocorrelation, a few widely used methods are available, including Moran's I, Geary's c, semi-variance analysis (details in Griffith 2013; Bivand et al., 2008; Zhang et al., 2009). If the presence of spatial autocorrelation is identified, 
several solutions are available. Consideration should be given to perform (a) a spatial regression (e.g., a Bayesian spatial model, simultaneous autoregressive model, or spatial lag model); (b) smoothing data using spatial filtering (Griffith 2013; Tiefelsdorf and Griffith, 2007); (c) randomising data using a Monte Carlo approach; and (d) applying local geographically weighted regressions (GWR). Detailed discussion and application of these tools can be found in Griffith (2013), Bivand et al. (2008), Waller and Gotway (2004), and Fotheringham et al. (2003). Overall, applying spatial models when testing the association between greenspace and health should be considered in future studies to ensure the associations are robust and free from biases due to inaccurate/improper use of spatial data and methods.

\subsection{Need for protocol and metadata}

Our review of the selected articles indicated great variety in the spatial scale, data, and methods used between the different studies investigating the relationships between greenspace and health. This variety of approaches makes a comparison of the studies difficult and complicates the generation of clear messages for policy and practice. There are also resultant difficulties in validating results and exploring dose responsiveness through the meta-analysis of greenspace and health relationships, issues as noted by Markevych et al. (2017) and Nordbø et al. (2018). Although Twohig-Bennett and Jones (2018) offered a meta-analysis of greenspace exposure and health outcomes (e.g., blood pressure), they used qualitative measures for comparing the highest and lowest level of greenspace exposure and failed to consider the scale, the type of spatial data, or the influence of different methodological approaches used in those studies, limiting the understanding of the degree and type of greenspace exposure that is crucial for a cumulative assessment of health impacts.

These issues call for the development of a standard protocol for using or reporting spatial scale, data, and methods in health and greenspace studies. Such a protocol would help to produce more consistent and practical measures for the implementation of greenspace-related strategies and help researchers conduct quantitative meta-analyses in the future. Currently, few protocols are available for using GIS in built environments and health-related studies (Forsyth, 2012; Forsyth, 2007), and those that are available are not typically focused on greenspace and health. However, existing protocols can aid researchers in developing other protocols for greenspace and health studies where the details of the scale definition, the exposure area, the best resolution spatial data, and the methodological approaches (e.g., buffer types and distances) would be listed based on the various foci of the studies (e.g., physical or mental health). In addition to a lack of developed protocol, we also found that the studies did not fully record the meta-data of the data types used in the analysis. If greenspace analysis is to become a key aspect of public health studies, then meta-data will be crucial to address validity, replicability issues (Habermann, 2018). Meta-data helps to understand spatial data in detail (e.g., resolution, data type), enables data sharing, and thus, it can be used to replicate, reproduce studies (Kedron et al., 2019); and meta-analyses, as well as to create actual policy decisions and programs for greenspace interventions for health. 


\subsection{Strengths, limitations and implications of this study}

Our systematic review has added key insights about the spatial dimensions widely used in health and greenspace studies (e.g., scale, exposure area, and spatial data). Unfortunately, the lack of consistent reporting of spatial methods and key spatial data characteristics meant it was not possible to conduct an associated meta-analysis. We observed wide heterogeneity across studies regarding data types; scale; exposure assessment approaches; analytical methods (e.g., statistical, types of regression, spatial associations); and health indicators. Additionally, several studies did not report all the information (e.g., the scale of analysis, buffer types, resolution of land use data) required to perform a meta-analysis considering spatial dimensions. We recommend that future studies provide meta-data to assist with conducting robust meta-analyses.

There were also some limitations in the systematic review. Firstly, papers with little explicit consideration of GIS and spatial analysis were not included. We recognise that underpinning research may have used such methods and that they were reported elsewhere. Thus, some studies where results were reported over several papers and reports were excluded. Secondly, there are some health-related outcomes that were not explicitly covered. For example, the analysis of associations between greenspace and cognitive development is an emerging area of research, and spatial data and methods are also integrated in such research (Browning and Rigolon, 2019; Markevych et al., 2019; Browning et al., 2018; de Keijzer et al., 2016; Dadvand et al., 2015). However, in this review, we limited our search terms to more explicitly health-related keywords, and these did not identify cognitive development-focused studies. We acknowledge that a review of how spatial dimensions influence the association between greenspace and cognitive development would also be useful. A systematic review by Browning and Rigolon (2019) provided critical insights about the association between greenspace and academic performance, and this review considered few spatial dimensions (e.g., buffer distances, GIS datasets). Thirdly, many of the studies were carried out urban settings, which may have a bearing on the results obtained. Finally, we recognise that this is a fast-moving field, and new studies emerge frequently. Our review provides insights into papers published within a particular time frame (i.e., 20092018). It inevitably excludes papers published outside of this period.

Despite these limitations, this review has vital practical and academic implications. It is one of the first review papers (to our knowledge) to consider most of the key spatial dimensions in the field of health and greenspace research. Thus, this paper provides suggestions for how researchers should design their investigations when determining scale, exposure area, exposure types, spatial data limitations, and further improvement opportunities. Furthermore, our categorisation of scale, data, and exposure types can act as a guideline for researchers to quantify greenspace exposure comprehensively. This can also help planners, practitioners, and policymakers to decide what type of greenspace exposure is needed at what scale in order to optimise the public health benefits of greenspace. Finally, this review indicated the need to develop protocols and meta-data that can help future researchers be more 
consistent in their processes. Greater consistency would allow the results to be more easily recreated, validated, and evaluated for transparency and reliability, qualities that are important when using data for meta-analyses and practical policy formulation.

\section{Conclusion}

In this paper, we have reviewed the overall usage and application of spatial theories and methods in greenspace and health related studies. We systematically reviewed 93 articles and critically assessed the spatial scale, data and analytics that are integrated into the methods and the processes by which we can understand the association between greenspace and health. We used this to identify the potential influence of spatial factors (e.g., scale, data, and exposure) on reported associations.

We found wide use of neighbourhood scales (mostly egocentric) in defining exposure areas, but noted that the variations in the scale of analysis influenced the level and strength of associations with health outcomes. In the determination of exposure, availability and accessibility were the most common measures. They were often used together though not consistently. In addition, we found less research into visibility exposure and temporal aspects, both of which are important for understanding the impact of greenspace on health. With respect to variation in scales, exposure areas and exposure types across the studies, we found the use of low and moderate resolution spatial data to be associated with the inadequate representation of greenspace. Amongst all of the studies we found inconsistencies in the use of exposure areas and GIS methods, especially for buffering and distance measurements, as well as ambiguity in reporting of spatial metadata, therefore we concluded the variations in the association between health and greenspace exposure might be (to some extent) caused by the variations in using different spatial scale, data, exposure types across different studies.

For future studies, we recommend the following:

\section{(i) Use of spatial data}

Future studies should consider using improved sources of spatial data (e.g., higher resolution satellite images). In particular, the use of open-access sentinel satellite images should be encouraged (Markevych et al., 2017) as well as finer resolution sources of other data used to represent greenspace.

\section{(ii) Selecting distance buffers and scales of analysis}

Selecting appropriate buffer distances should be a key consideration. Buffer distances set not only the exposure area but also the spatial unit and scale of analysis. Two key issues should be given more careful attention: (a) selecting buffers depending on the health focus (e.g., the existing evidence explaining physical and mental health associations) and (b) selecting distances based on the type of greenspace exposure data (e.g., the spatial resolution of satellite imagery; Su et al., 2019). The scale sensitivity of the data should be checked to understand the potential for MAUP and spatial 
autocorrelation. In addition, the type of buffers (e.g., aggregate buffers or overlapping or nested buffers; Browning and Lee, 2017) should be made clear in reporting to support meta-analyses.

(iii) Improved exposure assessment

Future studies should consider improving greenspace exposure assessments. In this regard, multi-scale composite exposure assessment (e.g., combined availability, accessibility, visibility) should be given a high priority.

\section{(iv) Spatial analysis}

In addition to classic statistical modelling to analyse the association between exposure and health, spatial modelling and regression approaches should be emphasised. It is particularly important to ensure that spatial autocorrelation tests are considered and any corrections made. Spatially explicit methods and local regression (e.g., GWR) can be usefully employed alongside classic statistical models.

(v) Metadata and protocol

In order to compare results (e.g., in a meta-analysis), check the validity of research outcomes, and maintain consistency in this area of research, we recommend the development of GIS protocols and the rigorous reporting of spatial meta-data related to greenspace and health studies.

\section{Acknowledgement}

The author would like to thank the three anonymous reviewers of this paper for their constructive comments and suggestions. First author is funded by SEED Postgraduate Research Scholarship at the University of Manchester.

\section{References}

Abelt, K. and McLafferty, S., 2017. Green streets: urban green and birth outcomes. International journal of environmental research and public health, 14(7), p.771. DOI http://dx.doi.org/10.3390/ijerph14070771

Agay-Shay, K., Michael, Y., Basagaña, X., Martínez-Solanas, Ė., Broday, D., Lensky, I.M., Rudolf, M., Rubin, L., Kent, R., Levy, N. and Haklai, Z., 2018. Mean and variance of greenness and pregnancy outcomes in Tel Aviv during 2000-14: longitudinal and cross-sectional approaches. International journal of epidemiology. DOI: https://doi.org/10.1093/ije/dyy249

Almanza, E., Jerrett, M., Dunton, G., Seto, E. and Pentz, M.A., 2012. A study of community design, greenness, and physical activity in children using satellite, GPS and accelerometer data. Health \& place, 18(1), pp.4654. DOI: https://doi.org/10.1016/j.healthplace.2011.09.003

Andrusaityte, S., Grazuleviciene, R., Kudzyte, J., Bernotiene, A., Dedele, A. and Nieuwenhuijsen, M.J., 2016. Associations between neighbourhood greenness and asthma in preschool children in Kaunas, Lithuania: a case-control study. BMJ open, 6(4), p.e010341. DOI: http://dx.doi.org/10.1136/bmjopen-2015-010341

ArcGIS Online Help. (2018). ArcGIS Online Help | ArcGIS, Doc.arcgis.com. [Online]. available at: http://doc.arcgis.com/en/arcgis-online/index.html (Accessed: 27 September 2018). 
Astell-Burt, T., Feng, X. and Kolt, G.S., 2014. Neighbourhood green space and the odds of having skin cancer: multilevel evidence of survey data from 267072 Australians. J Epidemiol Community Health, 68(4), pp.370374. DOI: http://dx.doi.org/10.1136/jech-2013-203043

Bethlehem, J.R., Mackenbach, J.D., Ben-Rebah, M., Compernolle, S., Glonti, K., Bárdos, H., Rutter, H.R., Charreire, H., Oppert, J.M., Brug, J. and Lakerveld, J., 2014. The SPOTLIGHT virtual audit tool: a valid and reliable tool to assess obesogenic characteristics of the built environment. International journal of health geographics, 13(1), p.52. DOI: https://doi.org/10.1186/1476-072X-13-52

Beyer, K.M., Kaltenbach, A., Szabo, A., Bogar, S., Nieto, F.J. and Malecki, K.M., 2014. Exposure to neighborhood green space and mental health: evidence from the survey of the health of Wisconsin. International journal of environmental research and public health, 11(3), pp.3453-3472. . DOI:10.3390/ijerph110303453

Bivand, R.S., Pebesma, E.J., Gomez-Rubio, V. and Pebesma, E.J., 2008. Applied spatial data analysis with R (Vol. 747248717). New York: Springer.

Boroushaki, S. and Malczewski, J., 2008. Implementing an extension of the analytical hierarchy process using ordered weighted averaging operators with fuzzy quantifiers in ArcGIS. Computers \& Geosciences, 34(4), pp.399-410. DOI: https://doi.org/10.1016/j.cageo.2007.04.003

Bratman, G.N., Anderson, C.B., Berman, M.G., Cochran, B., De Vries, S., Flanders, J., Folke, C., Frumkin, H., Gross, J.J., Hartig, T. and Kahn, P.H., 2019. Nature and mental health: An ecosystem service perspective. Science advances, 5(7), p.eaax0903. DOI: 10.1126/sciadv.aax0903

Bratman, G.N., Hamilton, J.P., Hahn, K.S., Daily, G.C. and Gross, J.J., 2015. Nature experience reduces rumination and subgenual prefrontal cortex activation. Proceedings of the national academy of sciences, 112(28), pp.8567-8572. DOI: https://doi.org/10.1073/pnas.1510459112

Brown, G., Schebella, M.F. and Weber, D., 2014. Using participatory GIS to measure physical activity and urban park benefits. Landscape and Urban Planning, 121, pp.34-44. DOI: https://doi.org/10.1016/j.landurbplan.2013.09.006

Browning, M.H. and Rigolon, A., 2019. School green space and its impact on academic performance: A systematic literature review. International journal of environmental research and public health, 16(3), p.429. DOI: https://doi.org/10.3390/ijerph16030429

Browning, M. and Rigolon, A., 2018. Do income, race and ethnicity, and sprawl influence the greenspace-human health link in city-level analyses? Findings from 496 cities in the United States. International journal of environmental research and public health, 15(7), p.1541. DOI: https://doi.org/10.3390/ijerph15071541

Browning, M.H., Kuo, M., Sachdeva, S., Lee, K. and Westphal, L., 2018. Greenness and school-wide test scores are not always positively associated-A replication of "linking student performance in Massachusetts elementary schools with the 'greenness' of school surroundings using remote sensing". Landscape and urban planning, 178, pp.69-72. DOI: https://doi.org/10.1016/j.landurbplan.2018.05.007

Browning, M. and Lee, K., 2017. Within what distance does "Greenness" best predict physical health? A systematic review of articles with GIS buffer analyses across the lifespan. International journal of environmental research and public health, 14(7), p.675. DOI: 10.3390/ijerph14070675.

Burgoine, T., Jones, A.P., Brouwer, R.J.N. and Neelon, S.E.B., 2015. Associations between BMI and home, school and route environmental exposures estimated using GPS and GIS: do we see evidence of selective daily mobility bias in children?. International journal of health geographics, 14(1), p.8. DOI: https://doi.org/10.1186/1476-072X-14-8

Chaix, B., Meline, J., Duncan, S., Merrien, C., Karusisi, N., Perchoux, C., Lewin, A., Labadi, K. and Kestens, Y., 2013. GPS tracking in neighborhood and health studies: a step forward for environmental exposure assessment, a step backward for causal inference?. Health \& Place, 21, pp.46-51. DOI: https://doi.org/10.1016/j.healthplace.2013.01.003

Chaix, B., Merlo, J., Evans, D., Leal, C. and Havard, S., 2009. Neighbourhoods in eco-epidemiologic research: delimiting personal exposure areas. A response to Riva, Gauvin, Apparicio and Brodeur. Social science \& medicine, 69(9), pp.1306-1310. DOI:10.1016/j.socscimed.2009.07.018

Chaix, B., Merlo, J. and Chauvin, P., 2005. Comparison of a spatial approach with the multilevel approach for investigating place effects on health: the example of healthcare utilisation in France. Journal of Epidemiology \& Community Health, 59(6), pp.517-526. DOI: http://dx.doi.org/10.1136/jech.2004.025478 
Christian, H., Ball, S.J., Zubrick, S.R., Brinkman, S., Turrell, G., Boruff, B. and Foster, S., 2017. Relationship between the neighbourhood built environment and early child development. Health \& place, 48, pp.90-101. DOI: https://doi.org/10.1016/j.healthplace.2017.08.010

City of Trees, 2011. Cityoftrees.org.uk; Greater Manchester Tree Audit [computer file]. (Manchester, UK). Personal communication, 2011.

Cleary, A., Roiko, A., Burton, N.W., Fielding, K.S., Murray, Z. and Turrell, G., 2019. Changes in perceptions of urban green space are related to changes in psychological well-being: Cross-sectional and longitudinal study of mid-aged urban residents. Health \& place, 59, p.102201. DOI: https://doi.org/10.1016/j.healthplace.2019.102201

Colombo, D., Serino, S., Tuena, C., Pedroli, E., Dakanalis, A., Cipresso, P. and Riva, G., 2017. Egocentric and allocentric spatial reference frames in aging: A systematic review. Neuroscience \& Biobehavioral Reviews, 80, pp.605-621. DOI: https://doi.org/10.1016/j.neubiorev.2017.07.012

Coombes, E., Jones, A.P. and Hillsdon, M., 2010. The relationship of physical activity and overweight to objectively measured green space accessibility and use. Social science \& medicine, 70(6), pp.816-822. DOI: https://doi.org/10.1016/j.socscimed.2009.11.020

Coppel, G. and Wüstemann, H., 2017. The impact of urban green space on health in Berlin, Germany: Empirical findings and implications for urban planning. Landscape and Urban Planning, 167, pp.410-418. DOI: https://doi.org/10.1016/j.landurbplan.2017.06.015

Cusack, L., Larkin, A., Carozza, S.E. and Hystad, P., 2017. Associations between multiple green space measures and birth weight across two US cities. Health \& place, 47, pp.36-43. DOI: https://doi.org/10.1016/i.healthplace.2017.07.002

Cutts, B.B., Darby, K.J., Boone, C.G. and Brewis, A., 2009. City structure, obesity, and environmental justice: an integrated analysis of physical and social barriers to walkable streets and park access. Social science \& medicine, 69(9), pp.1314-1322. DOI: https://doi.org/10.1016/j.socscimed.2009.08.020

Dadvand, P., Hariri, S., Abbasi, B., Heshmat, R., Qorbani, M., Motlagh, M.E., Basagaña, X. and Kelishadi, R., 2019. Use of green spaces, self-satisfaction and social contacts in adolescents: A population-based CASPIAN-V study. Environmental research, 168, pp.171-177. https://doi.org/10.1016/j.envres.2018.09.033

Dadvand, P. and Nieuwenhuijsen, M., 2019. Green space and health. In Integrating Human Health into Urban and Transport Planning (pp. 409-423). Springer, Cham.

Dadvand, P., Sunyer, J., Alvarez-Pedrerol, M., Dalmau-Bueno, A., Esnaola, M., Gascon, M., Pascual, M.D.C., Basagaña, X., Morgan, I.G. and Nieuwenhuijsen, M.J., 2017. Green spaces and spectacles use in schoolchildren in Barcelona. Environmental research, 152, pp.256-262. DOI: https://doi.org/10.1016/j.envres.2016.10.026

Dadvand, P., Villanueva, C.M., Font-Ribera, L., Martinez, D., Basagaña, X., Belmonte, J., Vrijheid, M., Gražulevičienè, R., Kogevinas, M. and Nieuwenhuijsen, M.J., 2014. Risks and benefits of green spaces for children: a cross-sectional study of associations with sedentary behavior, obesity, asthma, and allergy. Environmental health perspectives, 122(12), pp.1329-1335. https://doi.org/10.1289/ehp.1308038

Dadvand, P., Nieuwenhuijsen, M.J., Esnaola, M., Forns, J., Basagaña, X., Alvarez-Pedrerol, M., Rivas, I., LópezVicente, M., Pascual, M.D.C., Su, J. and Jerrett, M., 2015. Green spaces and cognitive development in primary schoolchildren. Proceedings of the National Academy of Sciences, 112(26), pp.7937-7942. DOI: https://doi.org/10.1073/pnas.1503402112

Dadvand, P., Sunyer, J., Basagana, X., Ballester, F., Lertxundi, A., Fernandez-Somoano, A., Estarlich, M., GarciaEsteban, R., Mendez, M.A. and Nieuwenhuijsen, M.J., 2012. Surrounding greenness and pregnancy outcomes in four Spanish birth cohorts. Environmental health perspectives, 120(10), pp.1481-1487. DOI: https://doi.org/10.1289/ehp.1205244

Dale, M.R. and Fortin, M.J., 2002. Spatial autocorrelation and statistical tests in ecology. Ecoscience, 9(2), pp.162167. DOI: https://doi.org/10.1080/11956860.2002.11682702

Dark, S.J. and Bram, D., 2007. The modifiable areal unit problem (MAUP) in physical geography. Progress in Physical Geography, 31(5), pp.471-479. DOI: 10.1177/0309133307083294 
De Keijzer, C., Tonne, C., Sabia, S., Basagaña, X., Valentín, A., Singh-Manoux, A., Antó, J.M., Alonso, J., Nieuwenhuijsen, M.J., Sunyer, J. and Dadvand, P., 2019. Green and blue spaces and physical functioning in older adults: Longitudinal analyses of the Whitehall II study. Environment international, 122, pp.346-356. DOI: https://doi.org/10.1016/j.envint.2018.11.046

De Keijzer, C., Gascon, M., Nieuwenhuijsen, M.J. and Dadvand, P., 2016. Long-term green space exposure and cognition across the life course: a systematic review. Current environmental health reports, 3(4), pp.468477. DOI: $10.1007 / \mathrm{s} 40572-016-0116-\mathrm{X}$

De Smith, M.J., Goodchild, M.F. and Longley, P., 2007. Geospatial analysis: a comprehensive guide to principles, techniques and software tools. Troubador Publishing Ltd.

Demoury, C., Thierry, B., Richard, H., Sigler, B., Kestens, Y. and Parent, M.E., 2017. Residential greenness and risk of prostate cancer: A case-control study in Montreal, Canada. Environment international, 98, pp.129136. DOI: https://doi.org/10.1016/j.envint.2016.10.024

Dempsey, S., Devine, M.T., Gillespie, T., Lyons, S. and Nolan, A., 2018. Coastal blue space and depression in older adults. Health \& place, 54, pp.110-117. DOI: https://doi.org/10.1016/j.healthplace.2018.09.002

Dennis, M., Barlow, D., Cavan, G., Cook, P., Gilchrist, A., Handley, J., James, P., Thompson, J., Tzoulas, K., Wheater, P. and Lindley, S., 2018. Mapping urban green infrastructure: a novel landscape-based approach to incorporating land-use and land-cover in the mapping of human-dominated systems. Land. DOI: $10.3390 /$ land7010017

Díaz, S., Pascual, U., Stenseke, M., Martín-López, B., Watson, R.T., Molnár, Z., Hill, R., Chan, K.M., Baste, I.A., Brauman, K.A. and Polasky, S., 2018. Assessing nature's contributions to people. Science, 359(6373), pp.270-272. DOI: $10.1126 /$ science.aap 8826

Díaz, S., Demissew, S., Carabias, J., Joly, C., Lonsdale, M., Ash, N., Larigauderie, A., Adhikari, J.R., Arico, S., Báldi, A. and Bartuska, A., 2015. The IPBES Conceptual Framework-connecting nature and people. Current Opinion in Environmental Sustainability, 14, pp.1-16. DOI: https://doi.org/10.1016/j.cosust.2014.11.002

Diniz - Filho, J.A.F., Bini, L.M. and Hawkins, B.A., 2003. Spatial autocorrelation and red herrings in geographical ecology. Global ecology and Biogeography, 12(1), pp.53-64. DOI: https://doi.org/10.1046/j.1466$\underline{822 X .2003 .00322 . x}$

Dunton, G.F., Almanza, E., Jerrett, M., Wolch, J. and Pentz, M.A., 2014. Neighborhood park use by children. American journal of preventive medicine, 46(2), pp.136-142. DOI: $10.1016 / \mathrm{j}$.amepre.2013.10.009

Dzhambov, A., Hartig, T., Markevych, I., Tilov, B. and Dimitrova, D., 2018a. Urban residential greenspace and mental health in youth: different approaches to testing multiple pathways yield different conclusions. Environmental research, 160, pp.47-59. DOI: https://doi.org/10.1016/j.envres.2017.09.015

Dzhambov, A.M., Markevych, I. and Lercher, P., 2018b. Greenspace seems protective of both high and low blood pressure among residents of an Alpine valley. Environment international, 121, pp.443-452. DOI: https://doi.org/10.1016/j.envint.2018.09.044

Dzhambov, A.M., Markevych, I., Hartig, T., Tilov, B., Arabadzhiev, Z., Stoyanov, D., Gatseva, P. and Dimitrova, D.D., 2018c. Multiple pathways link urban green-and bluespace to mental health in young adults. Environmental research, 166, pp.223-233. DOI: https://doi.org/10.1016/j.envres.2018.06.004

Egorov, A.I., Griffin, S.M., Converse, R.R., Styles, J.N., Sams, E.A., Wilson, A., Jackson, L.E. and Wade, T.J., 2017. Vegetated land cover near residence is associated with reduced allostatic load and improved biomarkers of neuroendocrine, metabolic and immune functions. Environmental research, 158, pp.508-521. DOI: https://doi.org/10.1016/j.envres.2017.07.009

Eisenman, T.S., Churkina, G., Jariwala, S.P., Kumar, P., Lovasi, G.S., Pataki, D.E., Weinberger, K.R. and Whitlow, T.H., 2019. Urban trees, air quality, and asthma: An interdisciplinary review. Landscape and urban planning, 187, pp.47-59. DOI: https://doi.org/10.1016/j.landurbplan.2019.02.010

ESRI. (2018). GIS for Health \& Social Care | Map Your Path to a Healthier Community, Esriuk.com. [Online]. available at: https://www.esriuk.com/en-gb/industries/health/overview (Accessed: 8 July 2018).

Frumkin, H., Bratman, G.N., Breslow, S.J., Cochran, B., Kahn Jr, P.H., Lawler, J.J., Levin, P.S., Tandon, P.S., Varanasi, U., Wolf, K.L. and Wood, S.A., 2017. Nature contact and human health: A research agenda. Environmental health perspectives, 125(7). DOI: https://doi.org/10.1289/EHP1663 
Fong, K.C., Hart, J.E. and James, P., 2018. A review of epidemiologic studies on greenness and health: Updated literature through 2017. Current environmental health reports, 5(1), pp.77-87. DOI: https://doi.org/10.1007/s40572-018-0179-y

Forsyth, A. 2007. Environment, food, and youth: GIS protocols. Retrieved September, 2018 from http://designforhealth.net/wp-content/uploads/2012/12/TREC_Protocol_V1 3 Nov2007.pdf

Forsyth, A. 2012. Neighborhood Environment for Active Transport-- Geographic Information Systems. Retrieved September, 2018 from http://designforhealth.net/wpcontent/uploads/2012/12/NEAT_GIS_V5 1_Jan2012.pdf

Fotheringham, A.S. and Rogerson, P.A. eds., 2008. The SAGE handbook of spatial analysis. Sage.

Fotheringham, A.S., Brunsdon, C. and Charlton, M., 2003. Geographically weighted regression: the analysis of spatially varying relationships. John Wiley \& Sons.

Fotheringham, A.S. and Wong, D.W., 1991. The modifiable areal unit problem in multivariate statistical analysis. Environment and planning A, 23(7), pp.1025-1044. DOI: https://doi.org/10.1068/a231025

Fuertes, E., Markevych, I., von Berg, A., Bauer, C.P., Berdel, D., Koletzko, S., Sugiri, D. and Heinrich, J., 2014. Greenness and allergies: evidence of differential associations in two areas in Germany. $J$ Epidemiol Community Health, 68(8), pp.787-790. DOI: 10.1136/jech-2014-203903.

Gascon, M., Sánchez-Benavides, G., Dadvand, P., Martínez, D., Gramunt, N., Gotsens, X., Cirach, M., Vert, C., Molinuevo, J.L., Crous-Bou, M. and Nieuwenhuijsen, M., 2018. Long-term exposure to residential green and blue spaces and anxiety and depression in adults: a cross-sectional study. Environmental research, 162, pp.231-239. DOI: https://doi.org/10.1016/j.envres.2018.01.012

Gascon, M., Triguero-Mas, M., Martínez, D., Dadvand, P., Rojas-Rueda, D., Plasència, A. and Nieuwenhuijsen, M.J., 2016. Residential green spaces and mortality: a systematic review. Environment international, 86, pp.60-67. DOI: https://doi.org/10.1016/j.envint.2015.10.013

Gascon, M., Triguero-Mas, M., Martínez, D., Dadvand, P., Forns, J., Plasència, A. and Nieuwenhuijsen, M.J., 2015. Mental health benefits of long-term exposure to residential green and blue spaces: a systematic review. International journal of environmental research and public health, 12(4), pp.4354-4379. DOI: DOI:10.3390/ijerph120404354

Gehl, J., 2013. Cities for people. Island press.

Giles-Corti, B. and Donovan, R.J., 2002. Socioeconomic status differences in recreational physical activity levels and real and perceived access to a supportive physical environment. Preventive medicine, 35(6), pp.601-611. DOI: https://doi.org/10.1006/pmed.2002.1115

Glazer, K.B., Eliot, M.N., Danilack, V.A., Carlson, L., Phipps, M.G., Dadvand, P., Savitz, D.A. and Wellenius, G.A., 2018. Residential green space and birth outcomes in a coastal setting. Environmental research, 163, pp.97-107. DOI: https://doi.org/10.1016/j.envres.2018.01.006

Griffith, D. and Chun, Y., 2016. Spatial autocorrelation and uncertainty associated with remotely-sensed data. Remote Sensing, 8(7), p.535. DOI: https://doi.org/10.3390/rs8070535

Griffith, D.A., 2013. Spatial autocorrelation and spatial filtering: gaining understanding through theory and scientific visualization. Springer Science \& Business Media.

Habermann, T., 2018. Metadata Life Cycles, Use Cases and Hierarchies. Geosciences, 8(5), p.179.

Halonen, J.I., Kivimäki, M., Pentti, J., Stenholm, S., Kawachi, I., Subramanian, S.V. and Vahtera, J., 2014. Green and blue areas as predictors of overweight and obesity in an 8 - year follow - up study. Obesity, 22(8), pp.1910-1917. DOI: 10.1002/oby.20772

Hartig, T., Mitchell, R., De Vries, S. and Frumkin, H., 2014. Nature and health. Annual review of public health, 35, pp.207-228. DOI: https://doi.org/10.1146/annurev-publhealth-032013-182443

Helbich, M., 2019. Spatiotemporal contextual uncertainties in green space exposure measures: Exploring a time series of the normalized difference vegetation indices. International journal of environmental research and public health, 16(5), p.852. DOI: https://doi.org/10.3390/ijerph16050852

Helbich, M., Yao, Y., Liu, Y., Zhang, J., Liu, P. and Wang, R., 2019. Using deep learning to examine street view green and blue spaces and their associations with geriatric depression in Beijing, China. Environment international, 126, pp.107-117. DOI: https://doi.org/10.1016/j.envint.2019.02.013 
Helbich, M., De Beurs, D., Kwan, M.P., O'Connor, R.C. and Groenewegen, P.P., 2018. Natural environments and suicide mortality in the Netherlands: a cross-sectional, ecological study. The Lancet Planetary Health, 2(3), pp.e134-e139. DOI: https://doi.org/10.1016/S2542-5196(18)30033-0

Helbich, M., 2018. Toward dynamic urban environmental exposure assessments in mental health research. Environmental research, 161, pp.129-135. DOI: https://doi.org/10.1016/j.envres.2017.11.006

Heywood, D.I., Cornelius, S.C. and Carver, S.J., 2011. An Introduction to Geographical Information Systems.

Hooper, P., Boruff, B., Beesley, B., Badland, H. and Giles-Corti, B., 2018. Testing spatial measures of public open space planning standards with walking and physical activity health outcomes: Findings from the Australian national liveability study. Landscape and Urban Planning, 171, pp.57-67. DOI: https://doi.org/10.1016/j.landurbplan.2017.12.001

Houlden, V., Weich, S., de Albuquerque, J.P., Jarvis, S. and Rees, K., 2018. The relationship between greenspace and the mental wellbeing of adults: a systematic review. PloS one, 13(9), p.e0203000. DOI: https://doi.org/10.1371/journal.pone.0203000

Houston, D., 2014. Implications of the modifiable areal unit problem for assessing built environment correlates of moderate and vigorous physical activity. Applied Geography, 50, pp.40-47. DOI: https://doi.org/10.1016/j.apgeog.2014.02.008

Huck, J.J., Whyatt, J.D., Coulton, P., Davison, B. and Gradinar, A., 2017. Combining physiological, environmental and locational sensors for citizen-oriented health applications. Environmental monitoring and assessment, 189(3), p.114. DOI: $\underline{10.1007 / \mathrm{s} 10661-017-5817-6}$

Huynh, Q., Craig, W., Janssen, I. and Pickett, W., 2013. Exposure to public natural space as a protective factor for emotional wellbeing among young people in Canada. BMC public health, 13(1), p.407. DOI: https://doi.org/10.1186/1471-2458-13-407

Hystad, P., Davies, H.W., Frank, L., Van Loon, J., Gehring, U., Tamburic, L. and Brauer, M., 2014. Residential greenness and birth outcomes: evaluating the influence of spatially correlated built-environment factors. Environmental health perspectives, 122(10), pp.1095-1102. https://doi.org/10.1289/ehp.1308049

Ihlebæk, C., Aamodt, G., Aradi, R., Claussen, B. and Thorén, K.H., 2018. Association between urban green space and self-reported lifestyle-related disorders in Oslo, Norway. Scandinavian journal of public health, 46(6), pp.589-596. DOI: https://doi.org/10.1177/1403494817730998

James, P., Hart, J.E., Banay, R.F. and Laden, F., 2016. Exposure to greenness and mortality in a nationwide prospective cohort study of women. Environmental health perspectives, 124(9), p.1344. DOI: https://doi.org/10.1289/ehp.1510363

Janhäll, S., 2015. Review on urban vegetation and particle air pollution-Deposition and dispersion. Atmospheric Environment, 105, pp.130-137. DOI: https://doi.org/10.1016/j.atmosenv.2015.01.052

Jansen, M., Kamphuis, C.B., Pierik, F.H., Ettema, D.F. and Dijst, M.J., 2018. Neighborhood-based PA and its environmental correlates: a GIS-and GPS based cross-sectional study in the Netherlands. BMC public health, 18(1), p.233. DOI: https://doi.org/10.1186/s12889-018-5086-5

Jansen, F.M., Ettema, D.F., Kamphuis, C.B.M., Pierik, F.H. and Dijst, M.J., 2017. How do type and size of natural environments relate to physical activity behaviour?. Health \& place, 46, pp.73-81. DOI: https://doi.org/10.1016/j.healthplace.2017.05.005

Jia, P., Cheng, X., Xue, H. and Wang, Y., 2017. Applications of geographic information systems (GIS) data and methods in obesity - related research. Obesity reviews, 18(4), pp.400-411. DOI: 10.1111/obr.12495

Jiang, B., Deal, B., Pan, H., Larsen, L., Hsieh, C.H., Chang, C.Y. and Sullivan, W.C., 2017. Remotely-sensed imagery vs. eye-level photography: Evaluating associations among measurements of tree cover density. Landscape urban planning, 157, pp.270-281. https://doi.org/10.1016/j.landurbplan.2016.07.010

Jonker, M.F., Van Lenthe, F.J., Donkers, B., Mackenbach, J.P. and Burdorf, A., 2014. The effect of urban green on small-area (healthy) life expectancy. J Epidemiol Community Health,68(10), pp.999-1002. DOI: http://dx.doi.org/10.1136/jech-2014-203847 
Kabisch, N., van den Bosch, M. and Lafortezza, R., 2017. The health benefits of nature-based solutions to urbanization challenges for children and the elderly-A systematic review. Environmental research, 159, pp.362-373. DOI: https://doi.org/10.1016/j.envres.2017.08.004

Kaplan, R., 2001. The nature of the view from home: Psychological benefits. Environment and behavior, 33(4), pp.507-542. DOI: $10.1177 / 00139160121973115$

Kaplan, R. and Kaplan, S., 1989. The experience of nature: A psychological perspective. CUP Archive.

Kaczynski, A.T., Besenyi, G.M., Stanis, S.A.W., Koohsari, M.J., Oestman, K.B., Bergstrom, R., Potwarka, L.R. and Reis, R.S., 2014. Are park proximity and park features related to park use and park-based physical activity among adults? Variations by multiple socio-demographic characteristics. International Journal of Behavioral Nutrition and Physical Activity, 11(1), p.146. DOI: https://doi.org/10.1186/s12966-014-0146-4

Kardan, O., Gozdyra, P., Misic, B., Moola, F., Palmer, L.J., Paus, T. and Berman, M.G., 2015. Neighborhood greenspace and health in a large urban center. Scientific reports, 5, p.11610. DOI: 10.1038/srep11610

Kedron, P., Frazier, A.E., Trgovac, A.B., Nelson, T. and Fotheringham, A.S., 2019. Reproducibility and Replicability in Geographical Analysis. Geographical Analysis. DOI: https://doi.org/10.1111/gean.12221

Kim, J.H., Lee, C. and Sohn, W., 2016. Urban natural environments, obesity, and health-related quality of life among hispanic children living in inner-city neighborhoods. International journal of environmental research and public health, 13(1), p.121. DOI:10.3390/ijerph13010121

Klingberg, J., Konarska, J., Lindberg, F., Johansson, L. and Thorsson, S., 2017. Mapping leaf area of urban greenery using aerial LiDAR and ground-based measurements in Gothenburg, Sweden. Urban Forestry \& Urban Greening, 26, pp.31-40. DOI: https://doi.org/10.1016/j.ufug.2017.05.011

Klompmaker, J.O., Hoek, G., Bloemsma, L.D., Gehring, U., Strak, M., Wijga, A.H., van den Brink, C., Brunekreef, B., Lebret, E. and Janssen, N.A., 2018. Green space definition affects associations of green space with overweight and physical activity. Environmental research, 160, pp.531-540. DOI: https://doi.org/10.1016/j.envres.2017.10.027

Koohsari, M.J., Kaczynski, A.T., Giles-Corti, B. and Karakiewicz, J.A., 2013. Effects of access to public open spaces on walking: Is proximity enough? Landscape and Urban Planning, 117, pp.92-99. DOI: https://doi.org/10.1016/j.landurbplan.2013.04.020

Kwan, M.P., 2018. The Limits of the Neighborhood Effect: Contextual Uncertainties in Geographic, Environmental Health, and Social Science Research. Annals of the American Association of Geographers, pp.1-9. DOI: 10.1080/24694452.2018.1453777

Laatikainen, T.E., Broberg, A. and Kyttä, M., 2017. The physical environment of positive places: Exploring differences between age groups. Preventive medicine, 95, pp.S85-S91. DOI: https://doi.org/10.1016/j.ypmed.2016.11.015

Labib, S.M., 2019. Investigation of the likelihood of green infrastructure (GI) enhancement along linear waterways or on derelict sites (DS) using machine learning. Environmental Modelling \& Software, 118, pp.146-165. DOI: https://doi.org/10.1016/j.envsoft.2019.05.006

Labib, S.M. and Harris, A., 2018. The potentials of Sentinel-2 and LandSat-8 data in green infrastructure extraction, using object based image analysis (OBIA) method. European Journal of Remote Sensing, 51(1), pp.231-240. DOI: https://doi.org/10.1080/22797254.2017.1419441

Larkin, A. and Hystad, P., 2018. Evaluating street view exposure measures of visible green space for health research. Journal of exposure science \& environmental epidemiology, p.1. DOI: 10.1038/s41370-018-00171.

Lee, A.C. and Maheswaran, R., 2011. The health benefits of urban green spaces: a review of the evidence. Journal of public health, 33(2), pp.212-222. DOI: https://doi.org/10.1093/pubmed/fdq068

Leslie, E., Sugiyama, T., Ierodiaconou, D. and Kremer, P., 2010. Perceived and objectively measured greenness of neighbourhoods: Are they measuring the same thing? Landscape and urban planning, 95(1-2), pp.28-33. DOI: https://doi.org/10.1016/j.landurbplan.2009.11.002

Li, X. and Ghosh, D., 2018. Associations between body mass index and urban "green" streetscape in Cleveland, Ohio, USA. International journal of environmental research and public health, 15(10), p.2186. DOI: https://doi.org/10.3390/ijerph15102186 
Liberati, A., Altman, D.G., Tetzlaff, J., Mulrow, C., Gøtzsche, P.C., Ioannidis, J.P., Clarke, M., Devereaux, P.J., Kleijnen, J. and Moher, D., 2009. The PRISMA statement for reporting systematic reviews and meta-analyses of studies that evaluate health care interventions: explanation and elaboration. PLoS medicine, 6(7), p.e1000100. DOI: https://doi.org/10.1136/bmj.b2700

Lindley, S. J., Cook, P. A., Dennis, M and Gilchrist, A. (2018) Biodiversity, physical health and climate change: a synthesis of recent evidence. Biodiversity, Health \& Climate Change Ed: Marselle, M., Bonn, A., Graner, T, Irvine, K, Stadler, J. \& Korn, H. Springer.

Longley, P.A., Goodchild, M.F., Maguire, D.J. and Rhind, D.W., 2015. Geographic information science and systems. John Wiley \& Sons.

Lovasi, G.S., Schwartz-Soicher, O., Quinn, J.W., Berger, D.K., Neckerman, K.M., Jaslow, R., Lee, K.K. and Rundle, A., 2013. Neighborhood safety and green space as predictors of obesity among preschool children from low-income families in New York City. Preventive medicine,57(3), pp.189-193. DOI: https://doi.org/10.1016/j.ypmed.2013.05.012

Malczewski, J., 2006. Ordered weighted averaging with fuzzy quantifiers: GIS-based multicriteria evaluation for land-use suitability analysis. International journal of applied earth observation and geoinformation, 8(4), pp.270-277. DOI: https://doi.org/10.1016/j.jag.2006.01.003

Markevych, I., Feng, X., Astell-Burt, T., Standl, M., Sugiri, D., Schikowski, T., Koletzko, S., Herberth, G., Bauer, C.P., von Berg, A. and Berdel, D., 2019. Residential and school greenspace and academic performance: Evidence from the GINIplus and LISA longitudinal studies of German adolescents. Environmental pollution, 245, pp.71-76. DOI: https://doi.org/10.1016/j.envpol.2018.10.053

Markevych, I., Schoierer, J., Hartig, T., Chudnovsky, A., Hystad, P., Dzhambov, A.M., De Vries, S., TrigueroMas, M., Brauer, M., Nieuwenhuijsen, M.J. and Lupp, G., 2017. Exploring pathways linking greenspace to health: Theoretical and methodological guidance. Environmental Research, 158, pp.301-317. DOI: https://doi.org/10.1016/j.envres.2017.06.028

Markevych, I., Standl, M., Sugiri, D., Harris, C., Maier, W., Berdel, D. and Heinrich, J., 2016. Residential greenness and blood lipids in children: A longitudinal analysis in GINIplus and LISAplus. Environmental research, 151, pp.168-173. DOI: https://doi.org/10.1016/j.envres.2016.07.037

Markevych, I., Tiesler, C.M., Fuertes, E., Romanos, M., Dadvand, P., Nieuwenhuijsen, M.J., Berdel, D., Koletzko, S. and Heinrich, J., 2014a. Access to urban green spaces and behavioural problems in children: Results from the GINIplus and LISAplus studies. Environment international, 71, pp.29-35. DOI: https://doi.org/10.1016/j.envint.2014.06.002

Markevych, I., Thiering, E., Fuertes, E., Sugiri, D., Berdel, D., Koletzko, S., von Berg, A., Bauer, C.P. and Heinrich, J., 2014b. A cross-sectional analysis of the effects of residential greenness on blood pressure in 10year old children: results from the GINIplus and LISAplus studies. BMC public health, 14(1), p.477. DOI: https://doi.org/10.1186/1471-2458-14-477

Matisziw, T.C., Nilon, C.H., Stanis, S.A.W., LeMaster, J.W., McElroy, J.A. and Sayers, S.P., 2016. The right space at the right time: The relationship between children's physical activity and land use/land cover. Landscape and urban planning, 151, pp.21-32. DOI: https://doi.org/10.1016/j.landurbplan.2016.03.006

McEachan, R.R.C., Prady, S.L., Smith, G., Fairley, L., Cabieses, B., Gidlow, C., Wright, J., Dadvand, P., Van Gent, D. and Nieuwenhuijsen, M.J., 2016. The association between green space and depressive symptoms in pregnant women: moderating roles of socioeconomic status and physical activity. J Epidemiol Community Health, 70(3), pp.253-259. DOI: http://dx.doi.org/10.1136/jech-2015-205954

McMorris, O., Villeneuve, P.J., Su, J. and Jerrett, M., 2015. Urban greenness and physical activity in a national $\begin{array}{llrl}\text { survey of Canadians. Environmental research, 137, pp.94-100. } & \text { DOI: }\end{array}$ https://doi.org/10.1016/j.envres.2014.11.010

Michael, Y.L., Nagel, C.L., Gold, R. and Hillier, T.A., 2014. Does change in the neighborhood environment prevent obesity in older women?. Social science \& medicine, 102, pp.129-137. DOI: https://doi.org/10.1016/j.socscimed.2013.11.047

Mitra, R. and Buliung, R.N., 2012. Built environment correlates of active school transportation: neighborhood and the modifiable areal unit problem. Journal of transport geography,20(1), pp.51-61. DOI: https://doi.org/10.1016/j.jtrangeo.2011.07.009 
Musa, G.J., Chiang, P.H., Sylk, T., Bavley, R., Keating, W., Lakew, B., Tsou, H.C. and Hoven, C.W., 2013. Use of GIS Mapping as a Public Health Tool--From Cholera to Cancer. Health services insights, 6, pp.HSIS10471. DOI: $10.4137 /$ HSI.S10471

Mukherjee, D., Safraj, S., Tayyab, M., Shivashankar, R., Patel, S.A., Narayanan, G., Ajay, V.S., Ali, M.K., Narayan, K.V., Tandon, N. and Prabhakaran, D., 2017. Park availability and major depression in individuals with chronic conditions: Is there an association in urban India?. Health \& place, 47, pp.54-62. DOI: https://doi.org/10.1016/j.healthplace.2017.07.004

Müller, G., Harhoff, R., Rahe, C. and Berger, K., 2018. Inner-city green space and its association with body mass index and prevalent type 2 diabetes: a cross-sectional study in an urban German city. BMJ open, 8(1), p.e019062. DOI: http://dx.doi.org/10.1136/bmjopen-2017-019062

Mytton, O.T., Townsend, N., Rutter, H. and Foster, C., 2012. Green space and physical activity: an observational study using Health Survey for England data. Health \& place, 18(5), pp.1034-1041. DOI: https://doi.org/10.1016/j.healthplace.2012.06.003

Nieuwenhuijsen, M.J., Khreis, H., Triguero-Mas, M., Gascon, M. and Dadvand, P., 2017. Fifty shades of green. Epidemiology, 28(1), pp.63-71. DOi: 10.1097/eDe.0000000000000549

Nguyen, Q.C., Sajjadi, M., McCullough, M., Pham, M., Nguyen, T.T., Yu, W., Meng, H.W., Wen, M., Li, F., Smith, K.R. and Brunisholz, K., 2018. Neighbourhood looking glass: $360^{\circ}$ automated characterisation of the built environment for neighbourhood effects research. J Epidemiol Community Health, pp.jech-2017. DOI: $\underline{10.1136 / \text { jech-2017-209456 }}$

Nordbø, E.C.A., Nordh, H., Raanaas, R.K. and Aamodt, G., 2018. GIS-derived measures of the built environment determinants of mental health and activity participation in childhood and adolescence: A systematic review. Landscape and Urban Planning, 177, pp.19-37. https://doi.org/10.1016/j.landurbplan.2018.04.009

Nowak, D.J., Hirabayashi, S., Bodine, A. and Greenfield, E., 2014. Tree and forest effects on air quality and human health in the United States. Environmental pollution, 193, pp.119-129. DOI: https://doi.org/10.1016/j.envpol.2014.05.028

Nutsford, D., Pearson, A.L., Kingham, S. and Reitsma, F., 2016. Residential exposure to visible blue space (but not green space) associated with lower psychological distress in a capital city. Health \& place, 39, pp.70-78. DOI: https://doi.org/10.1016/j.healthplace.2016.03.002

Office for National Statistics (2012). 2011 Census - Office for National Statistics. [online] Available at: https://www.ons.gov.uk/peoplepopulationandcommunity/populationandmigration/populationestimates/bulle tins/2011censuspopulationandhouseholdestimatesforsmallareasinenglandandwales/2012-11-23] [Accessed 11 May 2018].

Openshaw, S., 1984. The modifiable areal unit problem. Concepts and techniques in modern geography.

Pietilä, M., Neuvonen, M., Borodulin, K., Korpela, K., Sievänen, T. and Tyrväinen, L., 2015. Relationships between exposure to urban green spaces, physical activity and self-rated health. Journal of Outdoor Recreation and Tourism, 10, pp.44-54. DOI: https://doi.org/10.1016/j.jort.2015.06.006

Potestio, M.L., Patel, A.B., Powell, C.D., McNeil, D.A., Jacobson, R.D. and McLaren, L., 2009. Is there an association between spatial access to parks/green space and childhood overweight/obesity in Calgary, Canada?. International Journal of Behavioral Nutrition and Physical Activity,6(1), p.77. DOI: https://doi.org/10.1186/1479-5868-6-77

Ratti, C., 2004. Space syntax: some inconsistencies. Environment and Planning B: Planning and Design, 31(4), pp.487-499. DOI: $10.1068 / \mathrm{b} 3019$

Reid, C.E., Kubzansky, L.D., Li, J., Shmool, J.L. and Clougherty, J.E., 2018. It's not easy assessing greenness: a comparison of NDVI datasets and neighborhood types and their associations with self-rated health in New York City. Health \& place, 54, pp.92-101. DOI: https://doi.org/10.1016/j.healthplace.2018.09.005

Reid, C.E., Clougherty, J.E., Shmool, J.L. and Kubzansky, L.D., 2017. Is All Urban Green Space the Same? A Comparison of the Health Benefits of Trees and Grass in New York City. International journal of environmental research and public health, 14(11), p.1411. DOI:10.3390/ijerph14111411

Requia, W.J., Roig, H.L., Adams, M.D., Zanobetti, A. and Koutrakis, P., 2016. Mapping distance-decay of cardiorespiratory disease risk related to neighborhood environments. Environmental research, 151, pp.203215. DOI: $\underline{\text { https://doi.org/10.1016/j.envres.2016.07.038 }}$ 
Rhew, I.C., Vander Stoep, A., Kearney, A., Smith, N.L. and Dunbar, M.D., 2011. Validation of the normalized difference vegetation index as a measure of neighborhood greenness. Annals of epidemiology, 21(12), pp.946-952. DOI: https://doi.org/10.1016/j.annepidem.2011.09.001

Rodaway, P., 2002. Sensuous geographies: Body, sense and place. Routledge, Abingdon.

Rosenberg, M., 2017. Health geography III: Old ideas, new ideas or new determinisms?. Progress in Human Geography, 41(6), pp.832-842. DOI: $\underline{10.1177 / 0309132516670054}$

Rugel, E.J., Henderson, S.B., Carpiano, R.M. and Brauer, M., 2017. Beyond the Normalized Difference Vegetation Index (NDVI): Developing a Natural Space Index for population-level health research. Environmental research, 159, pp.474-483. DOI: https://doi.org/10.1016/j.envres.2017.08.033

Sarkar, C., Webster, C. and Gallacher, J., 2018. Residential greenness and prevalence of major depressive disorders: a cross-sectional, observational, associational study of 94879 adult UK Biobank participants. The Lancet Planetary Health, 2(4), pp.e162-e173. DOI: https://doi.org/10.1016/S2542-5196(18)30051-2

Sarkar, C., 2017. Residential greenness and adiposity: Findings from the UK Biobank. Environment international, 106, pp.1-10. DOI: https://doi.org/10.1016/j.envint.2017.05.016

Sarkar, C., Gallacher, J. and Webster, C., 2013. Urban built environment configuration and psychological distress in older men: Results from the Caerphilly study. BMC public health, 13(1), p.695. DOI: https://doi.org/10.1186/1471-2458-13-695

Schipperijn, J., Cerin, E., Adams, M.A., Reis, R., Smith, G., Cain, K., Christiansen, L.B., Van Dyck, D., Gidlow, C., Frank, L.D. and Mitáš, J., 2017. Access to parks and physical activity: An eight country comparison. Urban forestry \& urban greening, 27, pp.253-263. DOI: https://doi.org/10.1016/j.ufug.2017.08.010

Sefcik, J.S., Kondo, M.C., Klusaritz, H., Sarantschin, E., Solomon, S., Roepke, A., South, E.C. and Jacoby, S.F., 2019. Perceptions of Nature and Access to Green Space in Four Urban Neighborhoods. International journal of environmental research and public health, 16(13), p.2313. DOI: https://doi.org/10.3390/ijerph16132313

Silva, R.A., Rogers, K. and Buckley, T.J., 2018. Advancing Environmental Epidemiology to Assess the Beneficial Influence of the Natural Environment on Human Health and Well-Being. Environmental science \& technology, 52(17), pp.9545-9555. DOI: https://doi.org/10.1021/acs.est.8b01781

Stewart, O.T., Moudon, A.V., Littman, A.J., Seto, E. and Saelens, B.E., 2018. Why neighborhood park proximity is not associated with total physical activity. Health \& place, 52, pp.163-169. DOI: https://doi.org/10.1016/j.healthplace.2018.05.011

Sturm, R. and Cohen, D., 2014. Proximity to urban parks and mental health. The journal of mental health policy and economics, 17(1), p.19.

Su, J.G., Dadvand, P., Nieuwenhuijsen, M.J., Bartoll, X. and Jerrett, M., 2019. Associations of green space metrics with health and behavior outcomes at different buffer sizes and remote sensing sensor resolutions. Environment international, 126, pp.162-170. DOI: https://doi.org/10.1016/j.envint.2019.02.008

Su, S., Zhang, Q., Pi, J., Wan, C. and Weng, M., 2016. Public health in linkage to land use: Theoretical framework, empirical evidence, and critical implications for reconnecting health promotion to land use policy. Land Use Policy, 57, pp.605-618. DOI: https://doi.org/10.1016/j.landusepol.2016.06.030

Tamosiunas, A., Grazuleviciene, R., Luksiene, D., Dedele, A., Reklaitiene, R., Baceviciene, M., Vencloviene, J., Bernotiene, G., Radisauskas, R., Malinauskiene, V. and Milinaviciene, E., 2014. Accessibility and use of urban green spaces, and cardiovascular health: findings from a Kaunas cohort study. Environmental Health, 13(1), p.20. DOI: https://doi.org/10.1186/1476-069X-13-20

Taylor, L., Hahs, A.K. and Hochuli, D.F., 2018. Wellbeing and urban living: nurtured by nature. Urban ecosystems, 21(1), pp.197-208. DOI: https://doi.org/10.1007/s11252-017-0702-1

Tiefelsdorf, M. and Griffith, D.A., 2007. Semiparametric filtering of spatial autocorrelation: the eigenvector approach. Environment and Planning A, 39(5), pp.1193-1221. DOI: https://doi.org/10.1068/a37378

Triguero-Mas, M., Donaire-Gonzalez, D., Seto, E., Valentín, A., Martínez, D., Smith, G., Hurst, G., CarrascoTurigas, G., Masterson, D., van den Berg, M. and Ambròs, A., 2017a. Natural outdoor environments and mental health: Stress as a possible mechanism. Environmental research, 159, pp.629-638. DOI: https://doi.org/10.1016/j.envres.2017.08.048 
Triguero-Mas, M., Donaire-Gonzalez, D., Seto, E., Valentín, A., Smith, G., Martínez, D., Carrasco-Turigas, G., Masterson, D., van den Berg, M., Ambròs, A. and Martínez-Íñiguez, T., 2017b. Living close to natural outdoor environments in four European cities: adults' contact with the environments and physical activity. International journal of environmental research and public health,14(10), p.1162. DOI:10.3390/ijerph14101162

Triguero-Mas, M., Dadvand, P., Cirach, M., Martínez, D., Medina, A., Mompart, A., Basagaña, X., Gra ulevičienė, R. and Nieuwenhuijsen, M.J., 2015. Natural outdoor environments and mental and physical health: relationships and mechanisms. Environment international, 77, pp.35-41. DOI: https://doi.org/10.1016/j.envint.2015.01.012

Twohig-Bennett, C. and Jones, A., 2018. The health benefits of the great outdoors: A systematic review and metaanalysis of greenspace exposure and health outcomes. Environmental research, 166, pp.628-637. DOI: https://doi.org/10.1016/j.envres.2018.06.030

Ulmer, J.M., Wolf, K.L., Backman, D.R., Tretheway, R.L., Blain, C.J., O’Neil-Dunne, J.P. and Frank, L.D., 2016. Multiple health benefits of urban tree canopy: The mounting evidence for a green prescription. Health \& place, 42, pp.54-62. DOI: https://doi.org/10.1016/j.healthplace.2016.08.011

Ulrich, R.S., Simons, R.F., Losito, B.D., Fiorito, E., Miles, M.A. and Zelson, M., 1991. Stress recovery during exposure to natural and urban environments. Journal of environmental psychology, 11(3), pp.201-230. DOI: https://doi.org/10.1016/S0272-4944(05)80184-7

Ulrich, R., 1984. View through a window may influence recovery. Science, 224(4647), pp.224-225. DOI: $\underline{10.1126 / \text { science. } 6143402}$

U.S. Census Bureau (n.d.). Census tract. [online] Factfinder.census.gov. Available at: https://factfinder.census.gov/help/en/census_tract.htm [Accessed 11 Apr. 2018].

Van den Berg, M., van Poppel, M., Smith, G., Triguero-Mas, M., Andrusaityte, S., van Kamp, I., van Mechelen, W., Gidlow, C., Gražulevičiene, R., Nieuwenhuijsen, M.J. and Kruize, H., 2017. Does time spent on visits to green space mediate the associations between the level of residential greenness and mental health?. Urban Forestry \& Urban Greening, 25, pp.94-102. DOI: https://doi.org/10.1016/j.ufug.2017.04.010

Van den Berg, M., Wendel-Vos, W., Van Poppel, M., Kemper, H., Van Mechelen, W. and Maas, J., 2015. Health benefits of green spaces in the living environment: A systematic review of epidemiological studies. Urban Forestry \& Urban Greening, 14(4), pp.806-816. DOI: https://doi.org/10.1016/j.ufug.2015.07.008

Van den Bosch, M. and Bird, W. eds., 2018. Oxford Textbook of Nature and Public Health: The role of nature in improving the health of a population. Oxford University Press.

Van den Bosch, M. and Sang, Å.O., 2017. Urban natural environments as nature-based solutions for improved public health-A systematic review of reviews. Environmental research, 158, pp.373-384. DOI: https://doi.org/10.1016/j.envres.2017.05.040

Van Cauwenberg, J., De Bourdeaudhuij, I., De Meester, F., Van Dyck, D., Salmon, J., Clarys, P. and Deforche, B., 2011. Relationship between the physical environment and physical activity in older adults: a systematic review. Health \& place, 17(2), pp.458-469. DOI: https://doi.org/10.1016/j.healthplace.2010.11.010

Van Dillen, S.M., de Vries, S., Groenewegen, P.P. and Spreeuwenberg, P., 2012. Greenspace in urban neighbourhoods and residents' health: adding quality to quantity. J Epidemiol Community Health, 66(6), pp.e8-e8. DOI: http://dx.doi.org/10.1136/jech.2009.104695

Veitch, J., Abbott, G., Kaczynski, A.T., Stanis, S.A.W., Besenyi, G.M. and Lamb, K.E., 2016. Park availability and physical activity, TV time, and overweight and obesity among women: Findings from Australia and the United States. Health \& place, 38, pp.96-102. DOI: https://doi.org/10.1016/j.healthplace.2015.12.004

Vienneau, D., de Hoogh, K., Faeh, D., Kaufmann, M., Wunderli, J.M., Röösli, M. and SNC Study Group, 2017. More than clean air and tranquillity: Residential green is independently associated with decreasing mortality. Environment international, 108, pp.176-184. DOI: https://doi.org/10.1016/j.envint.2017.08.012

Villeneuve, P., Ysseldyk, R., Root, A., Ambrose, S., DiMuzio, J., Kumar, N., Shehata, M., Xi, M., Seed, E., Li, X. and Shooshtari, M., 2018. Comparing the normalized difference vegetation index with the Google street view measure of vegetation to assess associations between greenness, walkability, recreational physical activity, and health in Ottawa, Canada. International journal of environmental research and public health, 15(8), p.1719. DOI: https://doi.org/10.3390/ijerph15081719 
Vogt, S., Mielck, A., Berger, U., Grill, E., Peters, A., Döring, A., Holle, R., Strobl, R., Zimmermann, A.K., Linkohr, B. and Wolf, K., 2015. Neighborhood and healthy aging in a German city: distances to green space and senior service centers and their associations with physical constitution, disability, and health-related quality of life. European journal of ageing, 12(4), pp.273-283. https://doi.org/10.1007/s10433-015-0345-0

Vos, P.E., Maiheu, B., Vankerkom, J. and Janssen, S., 2013. Improving local air quality in cities: to tree or not to tree?. Environmental pollution, 183, pp.113-122. DOI: https://doi.org/10.1016/j.envpol.2012.10.021

Wade, T. and Sommer, S., 2006. A to Z GIS, An illustrated dictionary of geographic information systems. Esri Press.

Waller, L.A. and Gotway, C.A., 2004. Applied spatial statistics for public health data (Vol. 368). John Wiley \& Sons.

Ward, J.S., Duncan, J.S., Jarden, A. and Stewart, T., 2016. The impact of children's exposure to greenspace on physical activity, cognitive development, emotional wellbeing, and ability to appraise risk. Health \& Place, 40, pp.44-50. DOI: https://doi.org/10.1016/j.healthplace.2016.04.015

Ward Thompson, C, Aspinall, P. and Bell, S. eds., 2010. Innovative approaches to researching landscape and health: open space: people space 2. Routledge.

Ward Thompson, C, 2013. Activity, exercise and the planning and design of outdoor spaces. Journal of Environmental Psychology, 34, pp.79-96. DOI: https://doi.org/10.1016/j.jenvp.2013.01.003

Western Australian Planning Commission, 2015. Liveable Neighbourhoods. Available at: https://www.dplh.wa.gov.au/getmedia/afb82ec4-31a5-4a14-8af4-c840b3c2b81e/FUT-

LiveableNeighbourhoods_2015 [Accessed 29 July 2018]

Wheeler, B.W., Lovell, R., Higgins, S.L., White, M.P., Alcock, I., Osborne, N.J., Husk, K., Sabel, C.E. and Depledge, M.H., 2015. Beyond greenspace: an ecological study of population general health and indicators of natural environment type and quality. International journal of health geographics, 14(1), p.17. DOI: https://doi.org/10.1186/s12942-015-0009-5

Wheeler, B.W., Cooper, A.R., Page, A.S. and Jago, R., 2010. Greenspace and children's physical activity: a GPS/GIS analysis of the PEACH project. Preventive medicine, 51(2), pp.148-152. DOI: https://doi.org/10.1016/j.ypmed.2010.06.001

White, M.P., Pahl, S., Wheeler, B.W., Depledge, M.H. and Fleming, L.E., 2017. Natural environments and subjective wellbeing: Different types of exposure are associated with different aspects of wellbeing. Health \& place, 45, pp.77-84. DOI: https://doi.org/10.1016/j.healthplace.2017.03.008

Wilhelmsen, C.K., Skalleberg, K., Raanaas, R.K., Tveite, H. and Aamodt, G., 2017. Associations between green area in school neighbourhoods and overweight and obesity among Norwegian adolescents. Preventive medicine reports, 7, pp.99-105. DOI: https://doi.org/10.1016/j.pmedr.2017.05.020

Wilker, E.H., Wu, C.D., McNeely, E., Mostofsky, E., Spengler, J., Wellenius, G.A. and Mittleman, M.A., 2014. Green space and mortality following ischemic stroke. Environmental research, 133, pp.42-48. DOI: https://doi.org/10.1016/j.envres.2014.05.005

Wood, L., Hooper, P., Foster, S. and Bull, F., 2017. Public green spaces and positive mental health-investigating the relationship between access, quantity and types of parks and mental wellbeing. Health \& place, 48, pp.6371. DOI: $\underline{\text { https://doi.org/10.1016/j.healthplace.2017.09.002 }}$

Wu, J., Rappazzo, K.M., Simpson Jr, R.J., Joodi, G., Pursell, I.W., Mounsey, J.P., Cascio, W.E. and Jackson, L.E., 2018. Exploring links between greenspace and sudden unexpected death: A spatial analysis. Environment international, 113, pp.114-121. DOI: https://doi.org/10.1016/j.envint.2018.01.021

Wu, J. and Jackson, L., 2017. Inverse relationship between urban green space and childhood autism in California elementary school districts. Environment international, 107, $\quad$ pp.140-146. DOI: https://doi.org/10.1016/j.envint.2017.07.010

Xie, B., An, Z., Zheng, Y. and Li, Z., 2018. Healthy aging with parks: Association between park accessibility and the health status of older adults in urban China. Sustainable cities and society, 43, pp.476-486. DOI: https://doi.org/10.1016/j.scs.2018.09.010

Xu, S., Liu, Y., Wang, X. and Zhang, G., 2017. Scale effect on spatial patterns of ecosystem services and associations among them in semi-arid area: A case study in Ningxia Hui Autonomous Region, China. Science of the Total Environment, 598, pp.297-306. DOI: https://doi.org/10.1016/j.scitotenv.2017.04.009 
Yeager, R., Riggs, D.W., DeJarnett, N., Tollerud, D.J., Wilson, J., Conklin, D.J., O'Toole, T.E., McCracken, J., Lorkiewicz, P., Xie, Z. and Zafar, N., 2018. Association between residential greenness and cardiovascular disease risk. Journal of the American Heart Association,7(24), p.e009117. DOI: https://doi.org/10.1161/JAHA.118.009117

Yin, L., 2013. Assessing walkability in the city of Buffalo: Application of agent-based simulation. Journal of Urban Planning and Development, 139(3), pp.166-175. DOI: https://doi.org/10.1061/(ASCE)UP.1943$\underline{5444.0000147}$

Zandieh, R., Flacke, J., Martinez, J., Jones, P. and Van Maarseveen, M., 2017. Do Inequalities in Neighborhood Walkability Drive Disparities in Older Adults' Outdoor Walking?. International journal of environmental research and public health, 14(7), p.740. DOI:10.3390/ijerph14070740

Zenk, S.N., Schulz, A.J., Matthews, S.A., Odoms-Young, A., Wilbur, J., Wegrzyn, L., Gibbs, K., Braunschweig, C. and Stokes, C., 2011. Activity space environment and dietary and physical activity behaviors: a pilot study. Health \& place, 17(5), pp.1150-1161. DOI: https://doi.org/10.1016/j.healthplace.2011.05.001

Zhai, Y. and Baran, P.K., 2016. Do configurational attributes matter in context of urban parks? Park pathway configurational attributes and senior walking. Landscape and Urban Planning, 148, pp.188-202. DOI: https://doi.org/10.1016/j.landurbplan.2015.12.010

Zhang, L., Zhou, S., Kwan, M.P., Chen, F. and Lin, R., 2018. Impacts of individual daily greenspace exposure on health based on individual activity space and structural equation modeling. International journal of environmental research and public health, 15(10), p.2323. DOI: https://doi.org/10.3390/ijerph15102323

Zhang, Y., van Dijk, T., Tang, J. and Berg, A.E., 2015. Green space attachment and health: A comparative study in two urban neighborhoods. International journal of environmental research and public health, 12(11), pp.14342-14363. DOI:10.3390/ijerph121114342

Zhang, X., Hu, Y., Zhuang, D., Qi, Y. and Ma, X., 2009. NDVI spatial pattern and its differentiation on the Mongolian Plateau. Journal of geographical sciences, 19(4), pp.403-415. DOI: https://doi.org/10.1007/s11442-009-0403-7 


\section{Supplementary Document}

Table 1S: Search strings and their setup in WOS, Scopus and PubMed used in this review.

\begin{tabular}{|c|c|c|c|c|c|c|c|c|}
\hline \multirow{2}{*}{$\begin{array}{l}\text { SL } \\
\text { No. }\end{array}$} & \multirow{2}{*}{$\begin{array}{l}\text { Basic Search } \\
\text { String }\end{array}$} & \multicolumn{3}{|c|}{ Number of studies } & \multirow{2}{*}{$\begin{array}{l}\text { In String } \\
\text { Duplicate } \\
\text { Removed }\end{array}$} & \multirow[b]{2}{*}{ Exact String WOS } & \multirow[b]{2}{*}{ Exact String Scopus } & \multirow[b]{2}{*}{ Exact String PubMed } \\
\hline & & wos & Scopus & PubMed & & & & \\
\hline S1 & $\begin{array}{l}\text { (green space OR } \\
\text { blue space OR } \\
\text { greenspace OR } \\
\text { green } \\
\text { infrastructure } \\
\text { OR Urban green } \\
\text { space OR Urban } \\
\text { park OR } \\
\text { neighbourhood } \\
\text { greenness OR } \\
\text { urban tree) } \\
\text { AND (health } \\
\text { OR Public } \\
\text { Health OR } \\
\text { Mental health } \\
\text { OR physical } \\
\text { health OR } \\
\text { Obesity OR } \\
\text { Walkability OR } \\
\text { restoration OR } \\
\text { Children OR } \\
\text { Older Adults } \\
\text { OR Adults) } \\
\text { AND TS = (GIS } \\
\text { OR } \\
\text { geographical } \\
\text { OR Information } \\
\text { OR PPGIS OR } \\
\text { VGIS OR agent } \\
\text { based model) }\end{array}$ & 778 & 281 & 937 & 448 & $\begin{array}{l}((((\mathrm{TS}) \text { (green space } \\
\text { OR blue space OR } \\
\text { greenspace OR green } \\
\text { infrastructure OR } \\
\text { Urban green space OR } \\
\text { Urban park OR } \\
\text { neighbourhood } \\
\text { greenness OR urban } \\
\text { tree) AND TS = } \\
\text { (health OR Public } \\
\text { Health OR Mental } \\
\text { health OR physical } \\
\text { health OR Obesity OR } \\
\text { Walkability OR } \\
\text { restoration OR } \\
\text { Children OR Older } \\
\text { Adults OR Adults) } \\
\text { AND TS = (GIS OR } \\
\text { geographical OR } \\
\text { Information OR } \\
\text { PPGIS OR VGIS OR } \\
\text { agent based model) } \\
\text { ))) AND } \\
\text { LANGUAGE: } \\
\text { (English) AND } \\
\text { DOCUMENT TYPES: } \\
\text { (Article) } \\
\text { Timespan: 2009-2018 }\end{array}$ & $\begin{array}{l}\text { ( TITLE-ABS-KEY ( green AND space ) OR } \\
\text { TITLE-ABS-KEY ( blue AND space ) OR } \\
\text { TITLE-ABS-KEY ( greenspace ) OR TITLE- } \\
\text { ABS-KEY ( green AND infrastructure ) OR } \\
\text { TITLE-ABS-KEY ( urban AND green AND } \\
\text { space ) OR TITLE-ABS-KEY ( urban AND } \\
\text { park ) OR TITLE-ABS-KEY ( neighbourhood } \\
\text { AND greenness ) OR TITLE-ABS-KEY ( urban } \\
\text { AND tree ) AND TITLE-ABS-KEY ( health ) } \\
\text { OR TITLE-ABS-KEY ( public AND health ) } \\
\text { OR TITLE-ABS-KEY ( mental AND health ) } \\
\text { OR TITLE-ABS-KEY ( physical AND health ) } \\
\text { OR TITLE-ABS-KEY ( obesity ) OR TITLE- } \\
\text { ABS-KEY ( walkability ) OR TITLE-ABS-KEY } \\
\text { ( restoration ) OR TITLE-ABS-KEY ( children ) } \\
\text { OR TITLE-ABS-KEY ( older AND adults ) OR } \\
\text { TITLE-ABS-KEY ( adults ) AND TITLE-ABS- } \\
\text { KEY ( gis ) OR TITLE-ABS-KEY ( geographical } \\
\text { AND information ) OR TITLE-ABS-KEY ( } \\
\text { ppgis ) OR TITLE-ABS-KEY ( vgis ) OR } \\
\text { TITLE-ABS-KEY ( agent AND based AND } \\
\text { model ) ) AND ( LIMIT-TO ( DOCTYPE, "ar" ) } \\
\text { ) AND ( LIMIT-TO ( PUBYEAR, 2018) OR } \\
\text { LIMIT-TO ( PUBYEAR, 2017 ) OR LIMIT-TO } \\
\text { ( PUBYEAR, 2016 ) OR LIMIT-TO ( } \\
\text { PUBYEAR, 2015 ) OR LIMIT-TO ( PUBYEAR } \\
\text {, 2014 ) OR LIMIT-TO ( PUBYEAR, 2013 ) } \\
\text { OR LIMIT-TO ( PUBYEAR, 2012) OR } \\
\text { LIMIT-TO ( PUBYEAR, 2011 ) OR LIMIT-TO } \\
\text { ( PUBYEAR, 2010) OR LIMIT-TO ( } \\
\text { PUBYEAR, 2009 ) ) }\end{array}$ & $\begin{array}{l}\text { (((((()green[All Fields] AND space[All Fields]) OR (blue[All Fields] } \\
\text { AND space[All Fields]) OR greenspace[All Fields] OR (green[All } \\
\text { Fields] AND infrastructure[All Fields]]) OR (Urban[All Fields] AND } \\
\text { green[All Fields] AND space[All Fields]) OR ("parks, } \\
\text { recreational"[MeSH Terms] OR ("parks"[All Fields] AND } \\
\text { "recreational"[All Fields]) OR "recreational parks"[All Fields] OR } \\
\text { ("urban"[All Fields] AND "park"[All Fields]) OR "urban park"[All } \\
\text { Fields]) OR (("neighbourhood"[All Fields] OR "residence } \\
\text { characteristics"[MeSH Terms] OR ("residence"[All Fields] AND } \\
\text { "characteristics"[All Fields]) OR "residence characteristics"[All } \\
\text { Fields] OR "neighborhood"[All Fields]) AND greenness[All Fields]) } \\
\text { OR (urban[All Fields] AND ("trees"[MeSH Terms] OR "trees"[All } \\
\text { Fields] OR "tree"[All Fields]))) AND (("health"[MeSH Terms] OR } \\
\text { "health"[All Fields]) OR ("public health"[MeSH Terms] OR } \\
\text { ("public"[All Fields] AND "health"[All Fields]) OR "public } \\
\text { health"[All Fields]) OR ("mental health"[MeSH Terms] OR } \\
\text { ("mental"[All Fields] AND "health"[All Fields]) OR "mental } \\
\text { health"[All Fields]) OR (("physical examination"[MeSH Terms] OR } \\
\text { ("physical"[All Fields] AND "examination"[All Fields]) OR "physical } \\
\text { examination"[All Fields] OR "physical"[All Fields]) AND } \\
\text { ("health"[MeSH Terms] OR "health"[All Fields])) OR } \\
\text { ("obesity"[MeSH Terms] OR "obesity"[All Fields]) OR } \\
\text { Walkability[All Fields] OR restoration[All Fields] OR ("child"[MeSH } \\
\text { Terms] OR "child"[All Fields] OR "children"[All Fields]) OR } \\
\text { (Older[All Fields] AND ("adult"[MeSH Terms] OR "adult"[All } \\
\text { Fields] OR "adults"[All Fields])) OR ("adult"[MeSH Terms] OR } \\
\text { "adult"[All Fields] OR "adults"[All Fields]))) AND ("Proc ACM } \\
\text { SIGSPATIAL Int Conf Adv Inf"[Journal] OR "gis"[All Fields]) OR } \\
\text { geographical[All Fields] OR ("Information (Basel)"[Journal] OR } \\
\text { "information"[All Fields]) OR PPGIS[All Fields] OR VGIS[All } \\
\text { Fields] OR (agent[All Fields] AND based[All Fields] AND model[All } \\
\text { Fields])) AND ("2009/01/01"[PDAT] : "2018/12/31"[PDAT])) AND } \\
\text { Journal Article[ptyp]) AND Journal Article[ptyp] AND Journal } \\
\text { Article[ptyp] AND Journal Article[ptyp]) AND ((Journal Article[ptyp] } \\
\text { OR Clinical Trial[ptyp]) AND ("2009/01/01"[PDAT] : } \\
\text { "2018/12/31"[PDAT]))) AND (Journal Article[ptyp] AND } \\
\text { ("2009/01/01"[PDAT]: "2018/12/31"[PDAT])) }\end{array}$ \\
\hline
\end{tabular}




\begin{tabular}{|c|c|c|c|c|c|c|}
\hline S2 & $\begin{array}{l}\text { (Green space } \\
\text { OR blue space } \\
\text { OR greenspace } \\
\text { OR green } \\
\text { infrastructure } \\
\text { OR Urban green } \\
\text { space OR Urban } \\
\text { park OR } \\
\text { neighbourhood } \\
\text { greenness OR } \\
\text { urban tree) } \\
\text { AND (Health } \\
\text { OR Physical } \\
\text { Health OR } \\
\text { Mental Health } \\
\text { OR Walkability } \\
\text { OR Obesity OR } \\
\text { restoration) } \\
\text { AND (GIS OR } \\
\text { Geographic } \\
\text { Information OR } \\
\text { PPGIS OR } \\
\text { VGIS OR Agent } \\
\text { Based Model) }\end{array}$ & 323 & 320 & 224 & 363 & $\begin{array}{l}(\mathrm{TS}=(\text { green space OR } \\
\text { blue space OR } \\
\text { greenspace OR green } \\
\text { infrastructure OR } \\
\text { Urban green space OR } \\
\text { Urban park OR } \\
\text { neighbourhood } \\
\text { greenness OR urban } \\
\text { tree) AND TS = } \\
\text { (Health OR Physical } \\
\text { Health OR Mental } \\
\text { Health OR Walkability } \\
\text { OR Obesity OR } \\
\text { restoration) AND TS = } \\
\text { (GIS OR Geographic } \\
\text { Information OR } \\
\text { PPGIS OR VGIS OR } \\
\text { Agent Based Model)) } \\
\text { AND LANGUAGE: } \\
\text { (English) AND } \\
\text { DOCUMENT TYPES: } \\
\text { (Article) Timespan: } \\
\text { 2009-2018 }\end{array}$ \\
\hline
\end{tabular}

( TITLE-ABS-KEY ( green AND space) OR TITLE-ABS-KEY ( blue AND space) OR TITLE-ABS-KEY ( greenspace ) OR TITLEABS-KEY (green AND infrastructure) OR TITLE-ABS-KEY ( urban AND green AND space ) OR TITLE-ABS-KEY ( urban AND park ) OR TITLE-ABS-KEY ( neighbourhood AND greenness ) OR TITLE-ABS-KEY ( urban AND tree) AND TITLE-ABS-KEY ( health) OR TITLE-ABS-KEY (public AND helth) OR TITLE-ABS-KEY ( mublic AND healh) OR TITLE-ABS-KEY (physical AND hell ) OR TILE-ABS-KEY ( physical AND health ) ABS-KEY ( Walkabiliy) OR TITLE-ABS-KEY ( (restoration) AND TITLE-ABS-KEY ( gis ) OR TITLE-ABS-KEY (geographic AND information ) OR TITLE-ABS-KEY (ppgis) OR TITLE-

ABS-KEY (vgis ) OR TITLE-ABS-KEY ( agent AND based AND model) ) AND (LIMIT-TO ( DOCTYPE, "ar") ) AND ( LIMIT-TO (

PUBYEAR, 2018 ) OR LIMIT-TO ( PUBYEAR , 2017 ) OR LIMIT-TO ( PUBYEAR, 2016)

OR LIMIT-TO ( PUBYEAR, 2015) OR

LIMIT-TO ( PUBYEAR, 2014 ) OR LIMIT-TO

(PUBYEAR, 2013) OR LIMIT-TO (

PUBYEAR, 2012) OR LIMIT-TO ( PUBYEAR

2011) OR 2012) OR LIMIT-TO ( PUBYEAR

OR LIMIT-TO ( PUBYEAR, 2009) )
(((Green[All Fields] AND space[All Fields]) OR (blue[All Fields] AND space[All Fields]) OR greenspace[All Fields] OR (green[All Fields] AND infrastructure[All Fields]) OR (Urban[All Fields] AND green[All Fields] AND space[All Fields]) OR ("parks,

recreational"[MeSH Terms] OR ("parks"[All Fields] AND

"recreational"[All Fields]) OR "recreational parks"[All Fields] OR ("urban"[All Fields] AND "park"[All Fields]) OR "urban park"[All Fields]) OR (("neighbourhood"[All Fields] OR "residence

characteristics"[MeSH Terms] OR ("residence"[All Fields] AND "characteristics"[All Fields]) OR "residence characteristics"[All Fields] OR "neighborhood"[All Fields]) AND greenness[All Fields]) OR (urban[All Fields] AND ("trees"[MeSH Terms] OR "trees"[All "ind "health"[All Fields]) OR (("physical examination"[MeSH Terms] OR ("physical"[All Fields] AND "examination"[All Fields]) OR "physical examination"[All Fields] OR "physical"[All Fields]) AND

("health"[MeSH Terms] OR "health"[All Fields])) OR ("mental health"[MeSH Terms] OR ("mental"[All Fields] AND "health"[All Fields]) OR "mental health"[All Fields]) OR Walkability[All Fields] OR ("obesity"[MeSH Terms] OR "obesity"[All Fields]) OR restoration[All Fields])) AND (("Proc ACM SIGSPATIAL Int Conf Adv Inf"[Journal] OR "gis"[All Fields]) OR (Geographic[All Fields] AND ("Information (Basel)"[Journl] OR "information"[All Fields]) OR PPGIS[All Fields] OR VGIS[All Fields] OR (Aion [All Fields])) AND Based[All Fields] AND Model[All Fields])) AND (Journal Article[ptyp] AND ("2009/01/01"[PDAT] : "2018/12/31"[PDAT])) 


\begin{tabular}{|c|c|c|c|c|c|c|}
\hline S3 & $\begin{array}{l}\text { (neighbourhood) } \\
\text { AND (Green } \\
\text { space OR blue } \\
\text { space OR } \\
\text { greenspace OR } \\
\text { green } \\
\text { infrastructure } \\
\text { OR Urban green } \\
\text { space OR Urban } \\
\text { park OR } \\
\text { greenness OR } \\
\text { urban tree) } \\
\text { AND (Health } \\
\text { OR Physical } \\
\text { Health OR } \\
\text { Mental Health } \\
\text { OR Walkability } \\
\text { OR Obesity OR } \\
\text { restoration) }\end{array}$ & 901 & 575 & 713 & 847 & $\begin{array}{l}\text { (TS= } \text { (neighbourhood) } \\
\text { AND TS = (Green } \\
\text { space OR blue space } \\
\text { OR greenspace OR } \\
\text { green infrastructure } \\
\text { OR Urban green space } \\
\text { OR Urban park OR } \\
\text { greenness OR urban } \\
\text { tree) AND TS= } \\
\text { (Health OR Physical } \\
\text { Health OR Mental } \\
\text { Health OR Walkability } \\
\text { OR Obesity OR } \\
\text { restoration)) AND } \\
\text { LANGUAGE: } \\
\text { (English) AND } \\
\text { DOCUMENT TYPES: } \\
\text { (Article) } \\
\text { Timespan: 2009-2018. }\end{array}$ \\
\hline
\end{tabular}

( TITLE-ABS-KEY ( neighbourhood ) AND TITLE-ABS-KEY ( green AND space) OR TITLE-ABS-KEY (blue AND space) OR TITLE-ABS-KEY ( greenspace ) OR TITLEABS-KEY (green AND infrastructure) OR TITLE-ABS-KEY ( urban AND green AND space ) OR TITLE-ABS-KEY ( urban AND park ) OR TITLE-ABS-KEY ( neighbourhood AND greenness ) OR TITLE-ABS-KEY ( urban AND tree ) AND TITLE-ABS-KEY ( health) OR TITLE-ABS-KEY ( public AND health) OR TITLE-ABS-KEY ( ment AND hellh) OR TITLE-ABS-KEY ( physil AND halth) OR TILE-ABS-KEY ( physical AND health) OR THLE-ABS-KEY ( obesity) OR THLEABS-KEY (walkability) OR THLE-ABS-KEY (restoration)) AND (LIMIT-TO (DOCTYPE, ar" )) AND ( LIMIT-TO ( PUBYEAR, 2018) OR LIMIT-TO ( PUBYEAR, 2017) OR

LIMIT-TO ( PUBYEAR, 2016 ) OR LIMIT-TO (PUBYEAR, 2015 ) OR LIMIT-TO (

PUBYEAR, 2014 ) OR LIMIT-TO ( PUBYEAR , 2013 ) OR LIMIT-TO ( PUBYEAR, 2012 ) OR LIMIT-TO ( PUBYEAR, 2011 ) OR

LIMIT-TO ( PUBYEAR, 2010 ) OR LIMIT-TO (PUBYEAR, 2009) )
(("neighbourhood"[All Fields] OR "residence characteristics"[MeSH Terms] OR ("residence"[All Fields] AND "characteristics"[All Fields]) OR "residence characteristics"[All Fields] OR

"neighborhood"[All Fields]) AND ((Green[All Fields] AND space[All Fields]) OR (blue[All Fields] AND space[All Fields]) OR

greenspace[All Fields] OR (green[All Fields] AND infrastructure[All Fields]) OR (Urban[All Fields] AND green[All Fields] AND

space[All Fields]) OR ("parks, recreational"[MeSH Terms] OR

("parks"[All Fields] AND "recreational"[All Fields]) OR "recreational parks"[All Fields] OR ("urban"[All Fields] AND "park"[All Fields])

OR "urban park"[All Fields]) OR greenness[All Fields] OR (urban[All Fields] AND ("trees"[MeSH Terms] OR "trees"[All Fields] OR "tree"[All Fields])))) AND (("health"[MeSH Terms] OR "health"[All Fields]) OR (("physical examination"[MeSH Terms] OR

("physical"[All Fields] AND "examination"[All Fields]) OR "physical examination"[All Fields] OR "physical"[All Fields]) AND

("health"[MeSH Terms] OR "health"[All Fields])) OR ("mental

health"[MeSH Terms] OR ("mental"[All Fields] AND "health"[All

Fields]) OR "mental health"[All Fields]) OR Walkability[All Fields]

OR ("obesity"[MeSH Terms] OR "obesity"[All Fields]) OR

restoration[All Fields]) AND (Journal Article[ptyp] AND

("2009/01/01"[PDAT] : "2018/12/31"[PDAT])) 
Table 2S: Summary of extracted information from the 93 reviewed articles. Studies are first organised based on health focus, then alphabetically.

$\dagger$ Focus: $P H=$ Physical, $M H=$ Mental, $G=$ General Health; $\dagger \dagger$ Scale: $P R=$ Personal, $N H=$ Neighbourhood, $D / C=$ District $/$ City; ${ }^{\mu}$ Type: $C=$ Cross-sectional, $L=$ Longitudinal $;{ }^{\beta}$ Population: $C H=$ Children, $A D=$ Adults; OA: Older Adults.

NA $=$ Not Available or Not Used .

\begin{tabular}{|c|c|c|c|c|c|c|c|c|c|c|c|c|c|c|c|c|c|c|c|}
\hline Name & $\begin{array}{l}\text { Countr } \\
y\end{array}$ & $\begin{array}{l}\text { Fo } \\
\text { cus } \\
\dagger\end{array}$ & $\begin{array}{l}\text { Sca } \\
\text { le } \dagger \\
\dagger\end{array}$ & $\begin{array}{l}\text { T } \\
\text { yp } \\
\mathrm{e}^{\mu}\end{array}$ & $\begin{array}{l}\text { Main } \\
\text { Data } \\
\text { Source }\end{array}$ & $\begin{array}{l}\text { Ge } \\
\text { o- } \\
\text { Co } \\
\text { de }\end{array}$ & $\begin{array}{l}\text { Availabili } \\
\text { ty }\end{array}$ & Access & $\begin{array}{l}\text { Visib } \\
\text { ility }\end{array}$ & Tim & $\begin{array}{l}\text { Main } \\
\text { Buffer }\end{array}$ & $\begin{array}{l}\text { Multi } \\
\text { Buffe } \\
\text { r }\end{array}$ & $\begin{array}{c}\text { Buffer } \\
\text { Distan } \\
\text { ces }\end{array}$ & $\begin{array}{l}\text { GIS to } \\
\text { Measure } \\
\text { Health } \\
\text { indicator }\end{array}$ & $\begin{array}{l}\text { Main } \\
\text { Variable } \\
\text { (s)/ Form } \\
\text { Used }\end{array}$ & Analysis & $\begin{array}{l}\text { Sampl } \\
\text { e }\end{array}$ & $\begin{array}{l}\text { Po } \\
\text { pul } \\
\text { ati } \\
\text { on }^{\beta}\end{array}$ & $\begin{array}{l}\text { Main } \\
\text { Results }\end{array}$ \\
\hline $\begin{array}{l}\text { Abelt } \\
\text { and } \\
\text { McLaff } \\
\text { erty, } \\
2017\end{array}$ & USA & $\mathrm{PH}$ & $\mathrm{NH}$ & $\mathrm{C}$ & Satellite & Yes & $\begin{array}{l}\text { Tree } \\
\text { Canopy } \\
\text { and } \\
\text { Numbers }\end{array}$ & $\begin{array}{l}\text { Fixed } \\
\text { Distance }\end{array}$ & $\begin{array}{l}\text { Not } \\
\text { Used }\end{array}$ & $\begin{array}{l}\text { Not } \\
\text { Use } \\
\text { d }\end{array}$ & 500 & $\begin{array}{l}\text { Multi } \\
\text { Buffer }\end{array}$ & $\begin{array}{l}500, \\
800\end{array}$ & $\begin{array}{l}\text { Not } \\
\text { Used/Avai } \\
\text { lable }\end{array}$ & $\begin{array}{l}\text { Birth } \\
\text { Weight }\end{array}$ & $\begin{array}{l}\text { Statistica } \\
1\end{array}$ & $\begin{array}{l}10348 \\
4\end{array}$ & $\mathrm{CH}$ & $\begin{array}{l}\text { Mixed } \\
\text { Association } \\
\mathrm{s}\end{array}$ \\
\hline $\begin{array}{l}\text { Agay- } \\
\text { Shay et } \\
\text { al. } 2019\end{array}$ & Israel & $\mathrm{PH}$ & $\mathrm{NH}$ & $\mathrm{L}$ & Satellite & Yes & $\begin{array}{l}\text { NDVI } \\
\text { Value }\end{array}$ & $\begin{array}{l}\text { Shortest/ } \\
\text { Nearest } \\
\text { distance }\end{array}$ & $\begin{array}{l}\text { Not } \\
\text { Used }\end{array}$ & $\begin{array}{l}\text { Not } \\
\text { Use } \\
\text { d }\end{array}$ & 300 & $\begin{array}{l}\text { Multi } \\
\text { Buffer }\end{array}$ & $\begin{array}{l}100 \\
300, \\
500\end{array}$ & $\begin{array}{l}\text { Not } \\
\text { Used/Avai } \\
\text { lable }\end{array}$ & $\begin{array}{l}\text { Birth } \\
\text { Weight }\end{array}$ & $\begin{array}{l}\text { Statistica } \\
1\end{array}$ & 73221 & $\mathrm{AD}$ & $\begin{array}{l}\text { Positive } \\
\text { Availability } \\
\text { And } \\
\text { Accessibilit } \\
\text { y }\end{array}$ \\
\hline $\begin{array}{l}\text { Almanz } \\
\text { a et al., } \\
2012\end{array}$ & USA & $\mathrm{PH}$ & PR & $\mathrm{C}$ & Satellite & Yes & $\begin{array}{l}\text { NDVI } \\
\text { Value }\end{array}$ & $\begin{array}{l}\text { Not } \\
\text { Used/Av } \\
\text { ailable }\end{array}$ & $\begin{array}{l}\text { Not } \\
\text { Used }\end{array}$ & $\begin{array}{l}\text { Not } \\
\text { Use } \\
\text { d }\end{array}$ & 500 & $\begin{array}{l}\text { Multi } \\
\text { Buffer }\end{array}$ & $\begin{array}{l}30 \\
500\end{array}$ & $\begin{array}{l}\text { GPS and } \\
\text { Accelerom } \\
\text { eter }\end{array}$ & MVPA & $\begin{array}{l}\text { Statistica } \\
1\end{array}$ & 208 & $\mathrm{CH}$ & $\begin{array}{l}\text { Positive } \\
\text { Association } \\
\text { Availability }\end{array}$ \\
\hline $\begin{array}{l}\text { Andrus } \\
\text { aityte et } \\
\text { al., } 2016\end{array}$ & $\begin{array}{l}\text { Lithuan } \\
\text { ia }\end{array}$ & $\mathrm{PH}$ & $\mathrm{NH}$ & $\mathrm{C}$ & Satellite & Yes & $\begin{array}{l}\text { NDVI } \\
\text { Value }\end{array}$ & $\begin{array}{l}\text { Fixed } \\
\text { Distance }\end{array}$ & $\begin{array}{l}\text { Not } \\
\text { Used }\end{array}$ & $\begin{array}{l}\text { Not } \\
\text { Use } \\
\text { d }\end{array}$ & 100 & $\begin{array}{l}\text { Multi } \\
\text { Buffer }\end{array}$ & $\begin{array}{l}100 \\
300 \\
500\end{array}$ & $\begin{array}{l}\text { Not } \\
\text { Used/Avai } \\
\text { lable }\end{array}$ & Asthma & $\begin{array}{l}\text { Statistica } \\
1\end{array}$ & 1489 & $\mathrm{CH}$ & $\begin{array}{l}\text { Negative } \\
\text { Association }\end{array}$ \\
\hline $\begin{array}{l}\text { Astell- } \\
\text { Burt et } \\
\text { al., } 2014\end{array}$ & $\begin{array}{l}\text { Australi } \\
\mathrm{a}\end{array}$ & $\mathrm{PH}$ & $\mathrm{NH}$ & $\mathrm{C}$ & $\begin{array}{l}\text { Other } \\
\text { Land } \\
\text { Use Data }\end{array}$ & NA & Percentage & NA & $\begin{array}{l}\text { Not } \\
\text { Used }\end{array}$ & $\begin{array}{l}\text { Not } \\
\text { Use } \\
\text { d }\end{array}$ & 1000 & $\begin{array}{l}\text { Single } \\
\text { Buffer }\end{array}$ & & NA & $\begin{array}{l}\text { Skin } \\
\text { Cancer }\end{array}$ & $\begin{array}{l}\text { Statistica } \\
1\end{array}$ & $\begin{array}{l}26707 \\
2\end{array}$ & & $\begin{array}{l}\text { Negative } \\
\text { Association }\end{array}$ \\
\hline $\begin{array}{l}\text { Brown } \\
\text { et al., } \\
2014\end{array}$ & $\begin{array}{l}\text { Australi } \\
\mathrm{a}\end{array}$ & $\mathrm{PH}$ & $\mathrm{DC}$ & $\mathrm{C}$ & $\begin{array}{l}\text { WebMap } \\
\text { s }\end{array}$ & Yes & Area/size & $\begin{array}{l}\text { Shortest/ } \\
\text { Nearest } \\
\text { distance }\end{array}$ & $\begin{array}{l}\text { Not } \\
\text { Used }\end{array}$ & $\begin{array}{l}\text { Not } \\
\text { Use } \\
\text { d }\end{array}$ & NA & NA & & $\begin{array}{l}\text { Web- } \\
\text { GIS/PPGI } \\
\text { S }\end{array}$ & $\begin{array}{l}\text { General } \\
\text { health }\end{array}$ & $\begin{array}{l}\text { Spatial } \\
\text { Models/I } \\
\text { ndices } \\
\text { and } \\
\text { Statistica } \\
\text { 1 }\end{array}$ & NA & NA & $\begin{array}{l}\text { Mixed } \\
\text { Association } \\
\mathrm{s}\end{array}$ \\
\hline $\begin{array}{l}\text { Burgoin } \\
\text { e et al., } \\
2015\end{array}$ & USA & $\mathrm{PH}$ & PR & $\mathrm{C}$ & TIGER & Yes & Percentage & NA & $\begin{array}{l}\text { Not } \\
\text { Used }\end{array}$ & $\begin{array}{l}\text { Not } \\
\text { Use } \\
\text { d }\end{array}$ & 100 & $\begin{array}{l}\text { Multi } \\
\text { Buffer }\end{array}$ & $\begin{array}{l}100 \\
800\end{array}$ & GPS & BMI & $\begin{array}{l}\text { Statistica } \\
1\end{array}$ & 96 & $\mathrm{CH}$ & $\begin{array}{l}\text { Insignifican } \\
\mathrm{t} \\
\text { Association }\end{array}$ \\
\hline $\begin{array}{l}\text { Coombe } \\
\text { s et al., } \\
2010\end{array}$ & UK & $\mathrm{PH}$ & $\mathrm{NH}$ & $\mathrm{C}$ & $\begin{array}{l}\text { Master } \\
\text { Map }\end{array}$ & Yes & $\mathrm{NA}$ & $\begin{array}{l}\text { Shortest/ } \\
\text { Nearest } \\
\text { distance }\end{array}$ & $\begin{array}{l}\text { Not } \\
\text { Used }\end{array}$ & $\begin{array}{l}\text { Not } \\
\text { Use } \\
\text { d }\end{array}$ & 800 & $\begin{array}{l}\text { Single } \\
\text { Buffer }\end{array}$ & & $\mathrm{NA}$ & $\begin{array}{l}\text { Walking, } \\
\text { BMI }\end{array}$ & $\begin{array}{l}\text { Statistica } \\
1\end{array}$ & 7000 & NA & $\begin{array}{l}\text { Positive } \\
\text { Association } \\
\text { Accessibilit } \\
\mathrm{y}\end{array}$ \\
\hline $\begin{array}{l}\text { Cusack } \\
\text { et al., } \\
2017\end{array}$ & USA & $\mathrm{PH}$ & $\mathrm{NH}$ & $\mathrm{C}$ & Satellite & Yes & Percentage & $\begin{array}{l}\text { Fixed } \\
\text { Distance }\end{array}$ & $\begin{array}{l}\text { Not } \\
\text { Used }\end{array}$ & $\begin{array}{l}\text { Not } \\
\text { Use } \\
\text { d }\end{array}$ & 300 & $\begin{array}{l}\text { Single } \\
\text { Buffer }\end{array}$ & & NA & $\begin{array}{l}\text { Birth } \\
\text { Weight }\end{array}$ & $\begin{array}{l}\text { Statistica } \\
1\end{array}$ & $\begin{array}{l}17907 \\
2\end{array}$ & $\mathrm{CH}$ & $\begin{array}{l}\text { Mixed } \\
\text { Association } \\
\text { s }\end{array}$ \\
\hline
\end{tabular}




\begin{tabular}{|c|c|c|c|c|c|c|c|c|c|c|c|c|c|c|c|c|c|c|c|}
\hline $\begin{array}{l}\text { Cutts et } \\
\text { al., 2009 }\end{array}$ & USA & $\mathrm{PH}$ & $\mathrm{NH}$ & C & $\begin{array}{l}\text { Not } \\
\text { Availabl } \\
\mathrm{e}\end{array}$ & NA & NA & $\begin{array}{l}\text { Fixed } \\
\text { Distance }\end{array}$ & $\begin{array}{l}\text { Not } \\
\text { Used }\end{array}$ & $\begin{array}{l}\text { Not } \\
\text { Use } \\
\text { d }\end{array}$ & 400 & $\begin{array}{l}\text { Single } \\
\text { Buffer }\end{array}$ & & NA & $\begin{array}{l}\text { Obesity, } \\
\text { Walkability }\end{array}$ & $\begin{array}{l}\text { Statistica } \\
1\end{array}$ & 1024 & $\mathrm{AD}$ & $\begin{array}{l}\text { Positive } \\
\text { Association } \\
\text { Accessibilit } \\
\mathrm{y}\end{array}$ \\
\hline $\begin{array}{l}\text { Dadvan } \\
\text { d et al., } \\
2014\end{array}$ & Spain & $\mathrm{PH}$ & $\mathrm{NH}$ & $\mathrm{C}$ & Satellite & Yes & $\begin{array}{l}\text { NDVI } \\
\text { Value }\end{array}$ & $\begin{array}{l}\text { Fixed } \\
\text { Distance }\end{array}$ & $\begin{array}{l}\text { Not } \\
\text { Used }\end{array}$ & $\begin{array}{l}\text { Not } \\
\text { Use } \\
\mathrm{d}\end{array}$ & 300 & $\begin{array}{l}\text { Multi } \\
\text { Buffer }\end{array}$ & $\begin{array}{l}100 \\
250 \\
500 \\
1000\end{array}$ & NA & $\begin{array}{l}\text { Asthma, } \\
\text { Allergic, } \\
\text { Screen } \\
\text { time, } \\
\text { Obesity } \\
\text { and BMI }\end{array}$ & $\begin{array}{l}\text { Statistica } \\
1\end{array}$ & 3178 & $\mathrm{CH}$ & $\begin{array}{l}\text { Mixed } \\
\text { Association } \\
\mathrm{s}\end{array}$ \\
\hline $\begin{array}{l}\text { Dadvan } \\
\text { d et al., } \\
2017\end{array}$ & Spain & $\mathrm{PH}$ & $\mathrm{NH}$ & C & Satellite & Yes & $\begin{array}{l}\text { NDVI } \\
\text { Value }\end{array}$ & NA & $\begin{array}{l}\text { Not } \\
\text { Used }\end{array}$ & $\begin{array}{l}\text { Use } \\
\mathrm{d}\end{array}$ & 500 & $\begin{array}{l}\text { Multi } \\
\text { Buffer }\end{array}$ & $\begin{array}{l}100 \\
250 \\
500\end{array}$ & NA & $\begin{array}{l}\text { Use of } \\
\text { spectacles }\end{array}$ & $\begin{array}{l}\text { Statistica } \\
1\end{array}$ & 2727 & $\mathrm{CH}$ & $\begin{array}{l}\text { Positive } \\
\text { Association } \\
\text { Availability }\end{array}$ \\
\hline $\begin{array}{l}\text { De } \\
\text { Keijzer } \\
\text { et al., } \\
2019\end{array}$ & UK & $\mathrm{PH}$ & $\mathrm{NH}$ & L & Satellite & Yes & $\begin{array}{l}\text { NDVI } \\
\text { Value }\end{array}$ & $\begin{array}{l}\text { Shortest/ } \\
\text { Nearest } \\
\text { distance }\end{array}$ & $\begin{array}{l}\text { Not } \\
\text { Used }\end{array}$ & $\begin{array}{l}\text { Not } \\
\text { Use } \\
\mathrm{d}\end{array}$ & 1000 & $\begin{array}{l}\text { Multi } \\
\text { Buffer }\end{array}$ & $\begin{array}{l}500 \\
1000\end{array}$ & NA & $\begin{array}{l}\text { Physical } \\
\text { functioning }\end{array}$ & $\begin{array}{l}\text { Statistica } \\
1\end{array}$ & 5759 & $\mathrm{OA}$ & $\begin{array}{l}\text { Positive } \\
\text { Availability } \\
\text { And } \\
\text { Accessibilit } \\
\text { y }\end{array}$ \\
\hline $\begin{array}{l}\text { Demour } \\
\text { y et al., } \\
2017\end{array}$ & Canada & $\mathrm{PH}$ & $\mathrm{NH}$ & L & Satellite & Yes & $\begin{array}{l}\text { NDVI } \\
\text { Value }\end{array}$ & NA & $\begin{array}{l}\text { Not } \\
\text { Used }\end{array}$ & $\begin{array}{l}\text { Not } \\
\text { Use } \\
\text { d }\end{array}$ & 500 & $\begin{array}{l}\text { Multi } \\
\text { Buffer }\end{array}$ & $\begin{array}{l}150 \\
300 \\
500 \\
1000\end{array}$ & NA & $\begin{array}{l}\text { prostate } \\
\text { cancer risk }\end{array}$ & $\begin{array}{l}\text { Statistica } \\
1\end{array}$ & 1933 & $\mathrm{AD}$ & $\begin{array}{l}\text { Positive } \\
\text { Association } \\
\text { Availability }\end{array}$ \\
\hline $\begin{array}{l}\text { Dunton } \\
\text { et al., } \\
2014\end{array}$ & USA & $\mathrm{PH}$ & $\mathrm{NH}$ & $\mathrm{C}$ & Satellite & Yes & Area/size & $\begin{array}{l}\text { Shortest/ } \\
\text { Nearest } \\
\text { distance }\end{array}$ & $\begin{array}{l}\text { Not } \\
\text { Used }\end{array}$ & $\begin{array}{l}\text { Not } \\
\text { Use } \\
\text { d }\end{array}$ & 500 & $\begin{array}{l}\text { Single } \\
\text { Buffer }\end{array}$ & & $\begin{array}{l}\text { GPS and } \\
\text { Accelerom } \\
\text { eter }\end{array}$ & PA & $\begin{array}{l}\text { Statistica } \\
1\end{array}$ & 143 & $\mathrm{CH}$ & $\begin{array}{l}\text { Positive } \\
\text { Availability } \\
\text { And } \\
\text { Accessibilit } \\
\text { y }\end{array}$ \\
\hline $\begin{array}{l}\text { Dzhamb } \\
\text { ov et al., } \\
\text { 2018b }\end{array}$ & Austria & $\mathrm{PH}$ & $\mathrm{NH}$ & $\mathrm{C}$ & Satellite & Yes & $\begin{array}{l}\text { NDVI } \\
\text { Value }\end{array}$ & $\begin{array}{l}\text { Fixed } \\
\text { Distance }\end{array}$ & $\begin{array}{l}\text { Not } \\
\text { Used }\end{array}$ & $\begin{array}{l}\text { Not } \\
\text { Use } \\
\text { d }\end{array}$ & 500 & $\begin{array}{l}\text { Multi } \\
\text { Buffer }\end{array}$ & $\begin{array}{l}100 \\
300 \\
500 \\
1000\end{array}$ & $\mathrm{NA}$ & $\begin{array}{l}\text { Blood } \\
\text { pressure }\end{array}$ & $\begin{array}{l}\text { Statistica } \\
1\end{array}$ & 555 & $\mathrm{AD}$ & $\begin{array}{l}\text { Mixed } \\
\text { Association } \\
\mathrm{s}\end{array}$ \\
\hline $\begin{array}{l}\text { Glazer } \\
\text { et al. } \\
2018\end{array}$ & USA & PH & $\mathrm{NH}$ & C & Satellite & Yes & $\begin{array}{l}\text { NDVI } \\
\text { Value }\end{array}$ & $\begin{array}{l}\text { Both } \\
\text { Fixed } \\
\text { and } \\
\text { Shortest } \\
\text { Distances }\end{array}$ & $\begin{array}{l}\text { Not } \\
\text { Used }\end{array}$ & $\begin{array}{l}\text { Not } \\
\text { Use } \\
\text { d }\end{array}$ & 500 & $\begin{array}{l}\text { Multi } \\
\text { Buffer }\end{array}$ & $\begin{array}{l}150 \\
250 \\
500\end{array}$ & NA & $\begin{array}{l}\text { Preterm } \\
\text { birth, birth } \\
\text { weight }\end{array}$ & $\begin{array}{l}\text { Statistica } \\
1\end{array}$ & 61640 & $\mathrm{AD}$ & $\begin{array}{l}\text { Mixed } \\
\text { Association } \\
\text { s }\end{array}$ \\
\hline $\begin{array}{l}\text { Halonen } \\
\text { et al., } \\
2014\end{array}$ & Finland & PH & $\mathrm{NH}$ & L & $\begin{array}{l}\text { Other } \\
\text { Land } \\
\text { Use Data }\end{array}$ & Yes & NA & $\begin{array}{l}\text { Both } \\
\text { Fixed } \\
\text { and } \\
\text { Shortest } \\
\text { Distances }\end{array}$ & $\begin{array}{l}\text { Not } \\
\text { Used }\end{array}$ & $\begin{array}{l}\text { Not } \\
\text { Use } \\
\text { d }\end{array}$ & 250 & $\begin{array}{l}\text { Multi } \\
\text { Buffer }\end{array}$ & $\begin{array}{c}250, \\
500, \\
750,> \\
750\end{array}$ & NA & $\begin{array}{l}\text { Obesity, } \\
\text { BMI }\end{array}$ & $\begin{array}{l}\text { Statistica } \\
1\end{array}$ & 3225 & $\mathrm{AD}$ & $\begin{array}{l}\text { Positive } \\
\text { Association } \\
\text { Accessibilit } \\
\mathrm{y}\end{array}$ \\
\hline $\begin{array}{l}\text { Hooper } \\
\text { et al., } \\
2018\end{array}$ & $\begin{array}{l}\text { Australi } \\
\text { a }\end{array}$ & $\mathrm{PH}$ & $\mathrm{NH}$ & $\mathrm{L}$ & $\begin{array}{l}\text { Other } \\
\text { Land } \\
\text { Use Data }\end{array}$ & Yes & Percentage & $\begin{array}{l}\text { Both } \\
\text { Fixed } \\
\text { and } \\
\text { Shortest } \\
\text { Distances }\end{array}$ & $\begin{array}{l}\text { Not } \\
\text { Used }\end{array}$ & $\begin{array}{l}\text { Not } \\
\text { Use } \\
d\end{array}$ & 400 & $\begin{array}{l}\text { Multi } \\
\text { Buffer }\end{array}$ & $\begin{array}{l}400 \\
1600\end{array}$ & NA & PA & $\begin{array}{l}\text { Statistica } \\
1\end{array}$ & 995 & $\mathrm{AD}$ & $\begin{array}{l}\text { Mixed } \\
\text { Association } \\
\mathrm{s}\end{array}$ \\
\hline
\end{tabular}




\begin{tabular}{|c|c|c|c|c|c|c|c|c|c|c|c|c|c|c|c|c|c|c|c|}
\hline $\begin{array}{l}\text { Hystad } \\
\text { et al., } \\
2014\end{array}$ & Canada & $\mathrm{PH}$ & $\mathrm{NH}$ & $\mathrm{C}$ & Satellite & Yes & $\begin{array}{l}\text { NDVI } \\
\text { Value }\end{array}$ & NA & $\begin{array}{l}\text { Not } \\
\text { Used }\end{array}$ & $\begin{array}{l}\text { Not } \\
\text { Use } \\
\text { d }\end{array}$ & 100 & $\begin{array}{l}\text { Multi } \\
\text { Buffer }\end{array}$ & $\begin{array}{l}100 \\
250\end{array}$ & NA & $\begin{array}{l}\text { Preterm } \\
\text { birth, birth } \\
\text { weight }\end{array}$ & $\begin{array}{l}\text { Statistica } \\
1\end{array}$ & 61286 & $\mathrm{CH}$ & $\begin{array}{l}\text { Positive } \\
\text { Association } \\
\text { Availability }\end{array}$ \\
\hline $\begin{array}{l}\text { James } \\
\text { et al., } \\
2016\end{array}$ & USA & $\mathrm{PH}$ & $\mathrm{NH}$ & $\mathrm{L}$ & Satellite & Yes & $\begin{array}{l}\text { NDVI } \\
\text { Value }\end{array}$ & NA & $\begin{array}{l}\text { Not } \\
\text { Used }\end{array}$ & $\begin{array}{l}\text { Use } \\
\text { d }\end{array}$ & 250 & $\begin{array}{l}\text { Multi } \\
\text { Buffer }\end{array}$ & $\begin{array}{l}250 \\
1250\end{array}$ & NA & Mortality & $\begin{array}{l}\text { Statistica } \\
1\end{array}$ & $\begin{array}{l}10863 \\
0\end{array}$ & $\mathrm{AD}$ & $\begin{array}{l}\text { Positive } \\
\text { Association } \\
\text { Availability }\end{array}$ \\
\hline $\begin{array}{l}\text { Jansen } \\
\text { et al., } \\
2017\end{array}$ & $\begin{array}{l}\text { Netherl } \\
\text { ands }\end{array}$ & $\mathrm{PH}$ & $\mathrm{NH}$ & C & $\begin{array}{l}\text { Other } \\
\text { Land } \\
\text { Use Data }\end{array}$ & NA & Area/size & NA & $\begin{array}{l}\text { Not } \\
\text { Used }\end{array}$ & $\begin{array}{l}\text { Not } \\
\text { Use } \\
\mathrm{d}\end{array}$ & NA & NA & & $\begin{array}{l}\text { GPS and } \\
\text { Accelerom } \\
\text { eter }\end{array}$ & $\begin{array}{l}\text { MVPA, } \\
\text { LPA }\end{array}$ & $\begin{array}{l}\text { Statistica } \\
1\end{array}$ & 279 & $\mathrm{AD}$ & $\begin{array}{l}\text { Positive } \\
\text { Association } \\
\text { Availability }\end{array}$ \\
\hline $\begin{array}{l}\text { Jansen } \\
\text { et al., } \\
2108\end{array}$ & $\begin{array}{l}\text { Netherl } \\
\text { ands }\end{array}$ & $\mathrm{PH}$ & $\mathrm{NH}$ & $\mathrm{C}$ & $\begin{array}{l}\text { Other } \\
\text { Land } \\
\text { Use Data }\end{array}$ & Yes & Percentage & NA & $\begin{array}{l}\text { Not } \\
\text { Used }\end{array}$ & $\begin{array}{l}\text { Not } \\
\text { Use } \\
\text { d }\end{array}$ & 800 & $\begin{array}{l}\text { Multi } \\
\text { Buffer }\end{array}$ & $\begin{array}{l}400 \\
800 \\
1600\end{array}$ & $\begin{array}{l}\text { GPS and } \\
\text { Accelerom } \\
\text { eter }\end{array}$ & MVPA & $\begin{array}{l}\text { Statistica } \\
1\end{array}$ & 308 & $\mathrm{AD}$ & $\begin{array}{l}\text { Positive } \\
\text { Association } \\
\text { Availability }\end{array}$ \\
\hline $\begin{array}{l}\text { Kaczyns } \\
\text { ki et al.., } \\
2014\end{array}$ & USA & $\mathrm{PH}$ & $\mathrm{NH}$ & C & $\begin{array}{l}\text { Not } \\
\text { Availabl } \\
\text { e }\end{array}$ & Yes & $\begin{array}{l}\text { Area and } \\
\text { Numbers } \\
\text { of GBS }\end{array}$ & $\begin{array}{l}\text { Fixed } \\
\text { Distance }\end{array}$ & $\begin{array}{l}\text { Not } \\
\text { Used }\end{array}$ & $\begin{array}{l}\text { Not } \\
\text { Use } \\
\text { d }\end{array}$ & 805 & $\begin{array}{l}\text { Multi } \\
\text { Buffer }\end{array}$ & $\begin{array}{l}805 \\
1600\end{array}$ & NA & PA & $\begin{array}{l}\text { Statistica } \\
1\end{array}$ & 893 & $\mathrm{AD}$ & $\begin{array}{l}\text { Mixed } \\
\text { Association } \\
\mathrm{s}\end{array}$ \\
\hline $\begin{array}{l}\text { Kim et } \\
\text { al., } 2016\end{array}$ & USA & $\mathrm{PH}$ & $\mathrm{NH}$ & $\mathrm{C}$ & Satellite & Yes & $\begin{array}{l}\text { Percentage } \\
\text { and } \\
\text { Numbers }\end{array}$ & $\begin{array}{l}\text { Shortest/ } \\
\text { Nearest } \\
\text { distance }\end{array}$ & $\begin{array}{l}\text { Not } \\
\text { Used }\end{array}$ & $\begin{array}{l}\text { Not } \\
\text { Use } \\
\text { d }\end{array}$ & 400 & $\begin{array}{l}\text { Multi } \\
\text { Buffer }\end{array}$ & $\begin{array}{l}400 \\
800\end{array}$ & NA & BMI & $\begin{array}{l}\text { Spatial } \\
\text { Models/I } \\
\text { ndices } \\
\text { and } \\
\text { Statistica } \\
1\end{array}$ & 92 & $\mathrm{CH}$ & $\begin{array}{l}\text { Positive } \\
\text { Availability } \\
\text { And } \\
\text { Accessibilit } \\
\text { y }\end{array}$ \\
\hline $\begin{array}{l}\text { Klomp } \\
\text { maker } \\
\text { et al., } \\
2018\end{array}$ & $\begin{array}{l}\text { Netherl } \\
\text { ands }\end{array}$ & $\mathrm{PH}$ & $\mathrm{NH}$ & $\mathrm{C}$ & Satellite & Yes & $\begin{array}{l}\text { NDVI and } \\
\text { percentage }\end{array}$ & $\begin{array}{l}\text { Shortest/ } \\
\text { Nearest } \\
\text { distance }\end{array}$ & $\begin{array}{l}\text { Not } \\
\text { Used }\end{array}$ & $\begin{array}{l}\text { Use } \\
\mathrm{d}\end{array}$ & 300 & $\begin{array}{l}\text { Multi } \\
\text { Buffer }\end{array}$ & $\begin{array}{c}100 \\
300 \\
500 \\
1000 \\
3000\end{array}$ & NA & $\begin{array}{l}\text { BMI and } \\
150 \text { min } \\
\text { activity per } \\
\text { week }\end{array}$ & $\begin{array}{l}\text { Statistica } \\
1\end{array}$ & $\begin{array}{l}35482 \\
7\end{array}$ & $\mathrm{AD}$ & $\begin{array}{l}\text { Mixed } \\
\text { Association } \\
\mathrm{s}\end{array}$ \\
\hline $\begin{array}{l}\text { Koohsa } \\
\text { ri et al., } \\
2013\end{array}$ & $\begin{array}{l}\text { Australi } \\
\text { a }\end{array}$ & $\mathrm{PH}$ & $\mathrm{NH}$ & $\mathrm{C}$ & $\begin{array}{l}\text { Other } \\
\text { Land } \\
\text { Use Data }\end{array}$ & NA & $\begin{array}{l}\text { Area and } \\
\text { Numbers }\end{array}$ & $\begin{array}{l}\text { Shortest/ } \\
\text { Nearest } \\
\text { distance }\end{array}$ & $\begin{array}{l}\text { Not } \\
\text { Used }\end{array}$ & $\begin{array}{l}\text { Not } \\
\text { Use } \\
\text { d }\end{array}$ & 1000 & $\begin{array}{l}\text { Single } \\
\text { Buffer }\end{array}$ & & $\mathrm{NA}$ & PA & $\begin{array}{l}\text { Statistica } \\
1\end{array}$ & 320 & $\mathrm{AD}$ & $\begin{array}{l}\text { Positive } \\
\text { Availability } \\
\text { And } \\
\text { Accessibilit } \\
\text { y }\end{array}$ \\
\hline $\begin{array}{l}\text { Li and } \\
\text { Ghosh, } \\
2018\end{array}$ & USA & $\mathrm{PH}$ & $\mathrm{NH}$ & C & GSV & NA & NA & NA & Used & $\begin{array}{l}\text { Not } \\
\text { Use } \\
\text { d }\end{array}$ & NA & NA & & NA & BMI & $\begin{array}{l}\text { Spatial } \\
\text { Models/I } \\
\text { ndices } \\
\text { and } \\
\text { Statistica } \\
1\end{array}$ & 225 & $\mathrm{AD}$ & $\begin{array}{l}\text { Positive } \\
\text { Association } \\
\text { Visibility }\end{array}$ \\
\hline $\begin{array}{l}\text { Lovasi } \\
\text { et al., } \\
2013\end{array}$ & USA & $\mathrm{PH}$ & $\mathrm{NH}$ & $\mathrm{C}$ & $\begin{array}{l}\text { Other } \\
\text { Land } \\
\text { Use Data }\end{array}$ & Yes & $\begin{array}{l}\text { Percentage } \\
\text { and tree } \\
\text { canopy }\end{array}$ & NA & $\begin{array}{l}\text { Not } \\
\text { Used }\end{array}$ & $\begin{array}{l}\text { Not } \\
\text { Use } \\
d\end{array}$ & 400 & $\begin{array}{l}\text { Single } \\
\text { Buffer }\end{array}$ & & NA & Obesity & $\begin{array}{l}\text { Statistica } \\
1\end{array}$ & 11564 & $\mathrm{CH}$ & $\begin{array}{l}\text { Positive } \\
\text { Association } \\
\text { Availability }\end{array}$ \\
\hline $\begin{array}{l}\text { Markev } \\
\text { ych et } \\
\text { al., } \\
\text { 2014b }\end{array}$ & $\begin{array}{l}\text { German } \\
\mathrm{y}\end{array}$ & $\mathrm{PH}$ & $\mathrm{NH}$ & C & Satellite & NA & $\begin{array}{l}\text { NDVI } \\
\text { Value }\end{array}$ & NA & $\begin{array}{l}\text { Not } \\
\text { Used }\end{array}$ & $\begin{array}{l}\text { Not } \\
\text { Use } \\
\text { d }\end{array}$ & 500 & $\begin{array}{l}\text { Single } \\
\text { Buffer }\end{array}$ & & NA & $\begin{array}{l}\text { Blood } \\
\text { pressure }\end{array}$ & $\begin{array}{l}\text { Statistica } \\
1\end{array}$ & 2078 & $\mathrm{CH}$ & $\begin{array}{l}\text { Positive } \\
\text { Association } \\
\text { Availability }\end{array}$ \\
\hline $\begin{array}{l}\text { Matiszi } \\
\text { w et al., } \\
2016\end{array}$ & USA & $\mathrm{PH}$ & $\mathrm{DC}$ & $\mathrm{C}$ & $\begin{array}{l}\text { Other } \\
\text { Land } \\
\text { Use Data }\end{array}$ & NA & NA & NA & $\begin{array}{l}\text { Not } \\
\text { Used }\end{array}$ & $\begin{array}{l}\text { Use } \\
\text { d }\end{array}$ & NA & NA & & $\begin{array}{l}\text { GPS and } \\
\text { Accelerom } \\
\text { eter }\end{array}$ & MVPA & $\begin{array}{l}\text { Spatial } \\
\text { Models/I } \\
\text { ndices } \\
\text { and }\end{array}$ & 134 & $\mathrm{CH}$ & $\begin{array}{l}\text { Mixed } \\
\text { Association } \\
\mathrm{s}\end{array}$ \\
\hline
\end{tabular}




\begin{tabular}{|c|c|c|c|c|c|c|c|c|c|c|c|c|c|c|c|c|c|c|c|}
\hline & & & & & & & & & & & & & & & & $\begin{array}{l}\text { Statistica } \\
1\end{array}$ & & & \\
\hline $\begin{array}{l}\text { McMor } \\
\text { ris et } \\
\text { al., } \\
2015\end{array}$ & Canada & $\mathrm{PH}$ & $\mathrm{NH}$ & $\mathrm{C}$ & Satellite & Yes & $\begin{array}{l}\text { NDVI } \\
\text { Value }\end{array}$ & NA & $\begin{array}{l}\text { Not } \\
\text { Used }\end{array}$ & $\begin{array}{l}\text { Not } \\
\text { Use } \\
\text { d }\end{array}$ & 500 & $\begin{array}{l}\text { Multi } \\
\text { Buffer }\end{array}$ & $\begin{array}{l}30 \\
500\end{array}$ & NA & PA & $\begin{array}{l}\text { Statistica } \\
1\end{array}$ & $\begin{array}{l}12557 \\
6\end{array}$ & $\mathrm{AD}$ & $\begin{array}{l}\text { Positive } \\
\text { Association } \\
\text { Availability }\end{array}$ \\
\hline $\begin{array}{l}\text { Michael } \\
\text { et al., } \\
2014\end{array}$ & USA & $\mathrm{PH}$ & $\mathrm{NH}$ & $\mathrm{C}$ & TIGER & Yes & NA & $\begin{array}{l}\text { Shortest/ } \\
\text { Nearest } \\
\text { distance }\end{array}$ & $\begin{array}{l}\text { Not } \\
\text { Used }\end{array}$ & $\begin{array}{l}\text { Not } \\
\text { Use } \\
\text { d }\end{array}$ & NA & NA & & NA & BMI & $\begin{array}{l}\text { Statistica } \\
1\end{array}$ & 2003 & OA & $\begin{array}{l}\text { Insignifican } \\
\mathrm{t} \\
\text { Association }\end{array}$ \\
\hline $\begin{array}{l}\text { Müller } \\
\text { et al., } \\
2017\end{array}$ & $\begin{array}{l}\text { German } \\
\text { y }\end{array}$ & PH & $\mathrm{NH}$ & $\mathrm{C}$ & $\begin{array}{l}\text { Other } \\
\text { Land } \\
\text { Use Data }\end{array}$ & Yes & Percentage & NA & $\begin{array}{l}\text { Not } \\
\text { Used }\end{array}$ & $\begin{array}{l}\text { Not } \\
\text { Use } \\
\text { d }\end{array}$ & NA & NA & & NA & $\begin{array}{l}\text { BMI and } \\
\text { Diabetes } 2\end{array}$ & $\begin{array}{l}\text { Statistica } \\
1\end{array}$ & 1312 & $\mathrm{AD}$ & $\begin{array}{l}\text { Mixed } \\
\text { Association } \\
\mathrm{s}\end{array}$ \\
\hline $\begin{array}{l}\text { Mytton } \\
\text { et al., } \\
2012\end{array}$ & UK & $\mathrm{PH}$ & $\mathrm{NH}$ & $\mathrm{C}$ & $\begin{array}{l}\text { Other } \\
\text { Land } \\
\text { Use Data }\end{array}$ & Yes & Percentage & NA & $\begin{array}{l}\text { Not } \\
\text { Used }\end{array}$ & $\begin{array}{l}\text { Not } \\
\text { Use } \\
\text { d }\end{array}$ & NA & NA & & NA & PA & $\begin{array}{l}\text { Statistica } \\
1\end{array}$ & 2323 & $\mathrm{AD}$ & $\begin{array}{l}\text { Positive } \\
\text { Association } \\
\text { Availability }\end{array}$ \\
\hline $\begin{array}{l}\text { Nguyen } \\
\text { et al., } \\
2018\end{array}$ & USA & $\mathrm{PH}$ & $\mathrm{NH}$ & $\mathrm{C}$ & GSV & NA & Percentage & NA & Used & $\begin{array}{l}\text { Not } \\
\text { Use } \\
\text { d }\end{array}$ & $\mathrm{NA}$ & NA & & NA & Obesity & $\begin{array}{l}\text { Statistica } \\
1\end{array}$ & NA & NA & $\begin{array}{l}\text { Positive } \\
\text { Availability } \\
\text { And } \\
\text { Visibility }\end{array}$ \\
\hline $\begin{array}{l}\text { Pietile } \\
\text { et al., } \\
2015\end{array}$ & Finland & PH & $\mathrm{NH}$ & C & CORINE & Yes & Percentage & $\begin{array}{l}\text { Shortest/ } \\
\text { Nearest } \\
\text { distance }\end{array}$ & $\begin{array}{l}\text { Not } \\
\text { Used }\end{array}$ & $\begin{array}{l}\text { Not } \\
\text { Use } \\
\text { d }\end{array}$ & 1000 & $\begin{array}{l}\text { Single } \\
\text { Buffer }\end{array}$ & & NA & $\mathrm{PA}$ & $\begin{array}{l}\text { Statistica } \\
1\end{array}$ & 1867 & $\mathrm{AD}$ & $\begin{array}{l}\text { Positive } \\
\text { Availability } \\
\text { And } \\
\text { Accessibilit } \\
\text { y }\end{array}$ \\
\hline $\begin{array}{l}\text { Potestio } \\
\text { et al., } \\
2009\end{array}$ & Canada & PH & $\mathrm{NH}$ & $\mathrm{C}$ & $\begin{array}{l}\text { Other } \\
\text { Land } \\
\text { Use Data }\end{array}$ & Yes & $\begin{array}{l}\text { Percentage } \\
\text { and } \\
\text { Numbers }\end{array}$ & $\begin{array}{l}\text { Shortest/ } \\
\text { Nearest } \\
\text { distance }\end{array}$ & $\begin{array}{l}\text { Not } \\
\text { Used }\end{array}$ & $\begin{array}{l}\text { Not } \\
\text { Use } \\
\text { d }\end{array}$ & 800 & $\begin{array}{l}\text { Single } \\
\text { Buffer }\end{array}$ & & NA & BMI & $\begin{array}{l}\text { Statistica } \\
1\end{array}$ & 6772 & $\mathrm{CH}$ & $\begin{array}{l}\text { Insignifican } \\
\mathrm{t} \\
\text { Association }\end{array}$ \\
\hline $\begin{array}{l}\text { Reid et } \\
\text { al., } 2017\end{array}$ & USA & $\mathrm{PH}$ & $\mathrm{NH}$ & $\mathrm{C}$ & LiDER & Yes & $\begin{array}{l}\text { Tree } \\
\text { Canopy }\end{array}$ & NA & $\begin{array}{l}\text { Not } \\
\text { Used }\end{array}$ & $\begin{array}{l}\text { Not } \\
\text { Use } \\
\text { d }\end{array}$ & 1000 & $\begin{array}{l}\text { Multi } \\
\text { Buffer }\end{array}$ & $\begin{array}{l}300 \\
1000\end{array}$ & NA & $\begin{array}{l}\text { Health and } \\
\text { Mental } \\
\text { Hygiene }\end{array}$ & $\begin{array}{l}\text { Statistica } \\
1\end{array}$ & 1439 & $\mathrm{AD}$ & $\begin{array}{l}\text { Positive } \\
\text { Association } \\
\text { Availability }\end{array}$ \\
\hline $\begin{array}{l}\text { Rhew et } \\
\text { al., } 2011\end{array}$ & USA & $\mathrm{PH}$ & $\mathrm{NH}$ & $\mathrm{C}$ & Satellite & Yes & $\begin{array}{l}\text { NDVI } \\
\text { Value }\end{array}$ & NA & $\begin{array}{l}\text { Not } \\
\text { Used }\end{array}$ & $\begin{array}{l}\text { Not } \\
\text { Use } \\
\text { d }\end{array}$ & 100 & $\begin{array}{l}\text { Single } \\
\text { Buffer }\end{array}$ & & NA & & $\begin{array}{l}\text { Statistica } \\
1\end{array}$ & 131 & $\mathrm{AD}$ & $\begin{array}{l}\text { Mixed } \\
\text { Association } \\
\mathrm{s}\end{array}$ \\
\hline $\begin{array}{l}\text { Sarkar, } \\
2017\end{array}$ & UK & PH & $\mathrm{NH}$ & $\mathrm{C}$ & Satellite & Yes & $\begin{array}{l}\text { NDVI } \\
\text { Value }\end{array}$ & NA & $\begin{array}{l}\text { Not } \\
\text { Used }\end{array}$ & $\begin{array}{l}\text { Not } \\
\text { Use } \\
\text { d }\end{array}$ & 500 & $\begin{array}{l}\text { Single } \\
\text { Buffer }\end{array}$ & & NA & $\begin{array}{l}\text { BMI, } \\
\text { Obesity, } \\
\text { and related }\end{array}$ & $\begin{array}{l}\text { Statistica } \\
1\end{array}$ & $\begin{array}{l}33318 \\
3\end{array}$ & $\mathrm{AD}$ & $\begin{array}{l}\text { Positive } \\
\text { Association } \\
\text { Availability }\end{array}$ \\
\hline $\begin{array}{l}\text { Schippe } \\
\text { rijn et } \\
\text { al., } 2017\end{array}$ & Multi & $\mathrm{PH}$ & $\mathrm{NH}$ & $\mathrm{C}$ & $\begin{array}{l}\text { Other } \\
\text { Land } \\
\text { Use Data }\end{array}$ & Yes & $\begin{array}{l}\text { Area and } \\
\text { Numbers }\end{array}$ & $\begin{array}{l}\text { Shortest/ } \\
\text { Nearest } \\
\text { distance }\end{array}$ & $\begin{array}{l}\text { Not } \\
\text { Used }\end{array}$ & $\begin{array}{l}\text { Not } \\
\text { Use } \\
\text { d }\end{array}$ & 1000 & $\begin{array}{l}\text { Multi } \\
\text { Buffer }\end{array}$ & $\begin{array}{l}500 \\
1000\end{array}$ & $\begin{array}{l}\text { GPS and } \\
\text { Accelerom } \\
\text { eter }\end{array}$ & IPAQ-LF & $\begin{array}{l}\text { Statistica } \\
1\end{array}$ & 6181 & $\mathrm{AD}$ & $\begin{array}{l}\text { Mixed } \\
\text { Association } \\
\mathrm{s}\end{array}$ \\
\hline $\begin{array}{l}\text { Stewart } \\
\text { et al. } \\
2018\end{array}$ & USA & PH & $\mathrm{NH}$ & $\mathrm{L}$ & $\begin{array}{l}\text { Other } \\
\text { Land } \\
\text { Use Data }\end{array}$ & NA & $\begin{array}{l}\text { Area and } \\
\text { Numbers }\end{array}$ & $\begin{array}{l}\text { Fixed } \\
\text { Distance }\end{array}$ & $\begin{array}{l}\text { Not } \\
\text { Used }\end{array}$ & $\begin{array}{l}\text { Not } \\
\text { Use } \\
\text { d }\end{array}$ & 833 & $\begin{array}{l}\text { Single } \\
\text { Buffer }\end{array}$ & & $\begin{array}{l}\text { GPS and } \\
\text { Accelerom } \\
\text { eter }\end{array}$ & & $\begin{array}{l}\text { Statistica } \\
1\end{array}$ & 634 & $\mathrm{AD}$ & $\begin{array}{l}\text { Insignifican } \\
\mathrm{t} \\
\text { Association }\end{array}$ \\
\hline $\begin{array}{l}\text { Tamosi } \\
\text { unas et } \\
\text { al., } 2014\end{array}$ & $\begin{array}{l}\text { Lithuan } \\
\text { ia }\end{array}$ & PH & $\mathrm{NH}$ & $\mathrm{L}$ & $\begin{array}{l}\text { Other } \\
\text { Land } \\
\text { Use Data }\end{array}$ & NA & NA & $\begin{array}{l}\text { Fixed } \\
\text { Distance }\end{array}$ & $\begin{array}{l}\text { Not } \\
\text { Used }\end{array}$ & $\begin{array}{l}\text { Use } \\
\text { d }\end{array}$ & NA & NA & & NA & $\begin{array}{l}\text { CVD and } \\
\text { risk factors }\end{array}$ & $\begin{array}{l}\text { Statistica } \\
1\end{array}$ & 5112 & $\mathrm{AD}$ & $\begin{array}{l}\text { Positive } \\
\text { Association } \\
\text { Accessibilit } \\
\text { y }\end{array}$ \\
\hline
\end{tabular}




\begin{tabular}{|c|c|c|c|c|c|c|c|c|c|c|c|c|c|c|c|c|c|c|c|}
\hline $\begin{array}{l}\text { Triguer } \\
\text { o-Mas } \\
\text { et al., } \\
\text { 2017b }\end{array}$ & Spain & $\mathrm{PH}$ & $\mathrm{NH}$ & C & $\begin{array}{l}\text { Other } \\
\text { Land } \\
\text { Use Data }\end{array}$ & Yes & $\begin{array}{l}\text { Area and } \\
\text { Numbers }\end{array}$ & NA & $\begin{array}{l}\text { Not } \\
\text { Used }\end{array}$ & $\begin{array}{l}\text { Use } \\
\text { d }\end{array}$ & 300 & $\begin{array}{l}\text { Multi } \\
\text { Buffer }\end{array}$ & $\begin{array}{l}150 \\
300, \\
500, \\
1000\end{array}$ & $\begin{array}{l}\text { Smartpho } \\
\text { ne }\end{array}$ & MVPA & $\begin{array}{l}\text { Statistica } \\
1\end{array}$ & 409 & $\mathrm{AD}$ & $\begin{array}{l}\text { Others } \\
\text { Positive } \\
\text { Association } \\
\text { s Increased } \\
\text { time }\end{array}$ \\
\hline $\begin{array}{l}\text { Ulmer } \\
\text { et al., } \\
2016\end{array}$ & USA & $\mathrm{PH}$ & $\mathrm{NH}$ & $\mathrm{C}$ & LiDER & Yes & Percentage & NA & $\begin{array}{l}\text { Not } \\
\text { Used }\end{array}$ & $\begin{array}{l}\text { Not } \\
\text { Use } \\
d\end{array}$ & 250 & $\begin{array}{l}\text { Multi } \\
\text { Buffer }\end{array}$ & $\begin{array}{l}250, \\
500\end{array}$ & NA & PA, BMI & $\begin{array}{l}\text { Statistica } \\
1\end{array}$ & 4820 & $\mathrm{AD}$ & $\begin{array}{l}\text { Positive } \\
\text { Association } \\
\text { Availability }\end{array}$ \\
\hline $\begin{array}{l}\text { Veitch } \\
\text { et al., } \\
2016\end{array}$ & Multi & PH & $\mathrm{NH}$ & $\mathrm{C}$ & $\begin{array}{l}\text { Other } \\
\text { Land } \\
\text { Use Data }\end{array}$ & NA & $\begin{array}{l}\text { Area and } \\
\text { Numbers }\end{array}$ & $\begin{array}{l}\text { Fixed } \\
\text { Distance }\end{array}$ & $\begin{array}{l}\text { Not } \\
\text { Used }\end{array}$ & $\begin{array}{l}\text { Not } \\
\text { Use } \\
d\end{array}$ & 1600 & $\begin{array}{l}\text { Single } \\
\text { Buffer }\end{array}$ & & NA & $\begin{array}{l}\text { BMI, } \\
\text { Obesity, } \\
\text { and related }\end{array}$ & $\begin{array}{l}\text { Statistica } \\
1\end{array}$ & 2337 & $\mathrm{AD}$ & $\begin{array}{l}\text { Mixed } \\
\text { Association } \\
\mathrm{s}\end{array}$ \\
\hline $\begin{array}{l}\text { Viennea } \\
\text { u et al., } \\
2017\end{array}$ & $\begin{array}{l}\text { Switzerl } \\
\text { and }\end{array}$ & $\mathrm{PH}$ & $\mathrm{NH}$ & $\mathrm{L}$ & Satellite & Yes & $\begin{array}{l}\text { NDVI and } \\
\text { Percentage }\end{array}$ & NA & $\begin{array}{l}\text { Not } \\
\text { Used }\end{array}$ & $\begin{array}{l}\text { Not } \\
\text { Use } \\
\text { d }\end{array}$ & 500 & $\begin{array}{l}\text { Multi } \\
\text { Buffer }\end{array}$ & $\begin{array}{l}150 \\
500\end{array}$ & NA & Mortality & $\begin{array}{l}\text { Statistica } \\
1\end{array}$ & $\begin{array}{l}42846 \\
80\end{array}$ & $\mathrm{AD}$ & $\begin{array}{l}\text { Positive } \\
\text { Association } \\
\text { Availability }\end{array}$ \\
\hline $\begin{array}{l}\text { Villeneu } \\
\text { ve et al., } \\
2018\end{array}$ & Canada & $\mathrm{PH}$ & $\mathrm{NH}$ & C & Satellite & Yes & $\begin{array}{l}\text { NDVI } \\
\text { Value }\end{array}$ & NA & Used & $\begin{array}{l}\text { Not } \\
\text { Use } \\
\text { d }\end{array}$ & 250 & $\begin{array}{l}\text { Single } \\
\text { Buffer }\end{array}$ & & NA & SF 12 & $\begin{array}{l}\text { Statistica } \\
1\end{array}$ & 282 & $\mathrm{AD}$ & $\begin{array}{l}\text { Mixed } \\
\text { Association } \\
\mathrm{s}\end{array}$ \\
\hline $\begin{array}{l}\text { Vogt et } \\
\text { al., } 2015\end{array}$ & $\begin{array}{l}\text { German } \\
\mathrm{y}\end{array}$ & $\mathrm{PH}$ & $\mathrm{NH}$ & $\mathrm{C}$ & $\begin{array}{l}\text { Other } \\
\text { Land } \\
\text { Use Data }\end{array}$ & Yes & NA & $\begin{array}{l}\text { Both } \\
\text { Fixed } \\
\text { and } \\
\text { Shortest } \\
\text { Distances }\end{array}$ & $\begin{array}{l}\text { Not } \\
\text { Used }\end{array}$ & $\begin{array}{l}\text { Not } \\
\text { Use } \\
\text { d }\end{array}$ & 800 & $\begin{array}{l}\text { Multi } \\
\text { Buffer }\end{array}$ & $\begin{array}{c}200, \\
400, \\
800,> \\
800\end{array}$ & NA & $\begin{array}{l}\text { Physcial } \\
\text { condition, } \\
\text { Disability }\end{array}$ & $\begin{array}{l}\text { Statistica } \\
1\end{array}$ & 1711 & $\mathrm{OA}$ & $\begin{array}{l}\text { Insignifican } \\
\mathrm{t} \\
\text { Association }\end{array}$ \\
\hline $\begin{array}{l}\text { Wilhel } \\
\text { msen et } \\
\text { al., } 2017\end{array}$ & Norway & PH & $\mathrm{NH}$ & $\mathrm{C}$ & $\begin{array}{l}\text { Other } \\
\text { Land } \\
\text { Use Data }\end{array}$ & Yes & Percentage & NA & $\begin{array}{l}\text { Not } \\
\text { Used }\end{array}$ & $\begin{array}{l}\text { Not } \\
\text { Use } \\
\text { d }\end{array}$ & 1000 & $\begin{array}{l}\text { Multi } \\
\text { Buffer }\end{array}$ & $\begin{array}{l}1000 \\
5000\end{array}$ & NA & BMI & $\begin{array}{l}\text { Statistica } \\
1\end{array}$ & 10527 & $\mathrm{CH}$ & $\begin{array}{l}\text { Negative } \\
\text { Association }\end{array}$ \\
\hline $\begin{array}{l}\text { Wilker } \\
\text { et al., } \\
2014\end{array}$ & USA & $\mathrm{PH}$ & $\mathrm{NH}$ & $\mathrm{L}$ & Satellite & Yes & $\begin{array}{l}\text { NDVI } \\
\text { Value }\end{array}$ & NA & $\begin{array}{l}\text { Not } \\
\text { Used }\end{array}$ & $\begin{array}{l}\text { Not } \\
\text { Use } \\
\text { d }\end{array}$ & NA & NA & & NA & $\begin{array}{l}\text { ischemic } \\
\text { stroke }\end{array}$ & $\begin{array}{l}\text { Statistica } \\
1\end{array}$ & 1645 & $\mathrm{AD}$ & $\begin{array}{l}\text { Positive } \\
\text { Association } \\
\text { Availability }\end{array}$ \\
\hline $\begin{array}{l}\text { Wolch } \\
\text { et al., } \\
2011\end{array}$ & USA & $\mathrm{PH}$ & $\mathrm{NH}$ & $\mathrm{L}$ & $\begin{array}{l}\text { Other } \\
\text { Land } \\
\text { Use Data }\end{array}$ & Yes & NA & $\begin{array}{l}\text { Fixed } \\
\text { Distance }\end{array}$ & $\begin{array}{l}\text { Not } \\
\text { Used }\end{array}$ & $\begin{array}{l}\text { Not } \\
\text { Use } \\
\text { d }\end{array}$ & 500 & $\begin{array}{l}\text { Multi } \\
\text { Buffer }\end{array}$ & $\begin{array}{l}250 \\
500, \\
750\end{array}$ & NA & BMI & $\begin{array}{l}\text { Statistica } \\
1\end{array}$ & 3173 & $\mathrm{CH}$ & $\begin{array}{l}\text { Positive } \\
\text { Association } \\
\text { Accessibilit } \\
\text { y }\end{array}$ \\
\hline $\begin{array}{l}\text { Wu et } \\
\text { al., } 2018\end{array}$ & USA & $\mathrm{PH}$ & $\mathrm{NH}$ & $\mathrm{C}$ & Satellite & Yes & $\begin{array}{l}\text { Percentage } \\
\text { and tree } \\
\text { canopy }\end{array}$ & NA & $\begin{array}{l}\text { Not } \\
\text { Used }\end{array}$ & $\begin{array}{l}\text { Not } \\
\text { Use } \\
\text { d }\end{array}$ & NA & NA & & NA & $\begin{array}{l}\text { Sudden } \\
\text { Unexpecte } \\
\text { d death }\end{array}$ & $\begin{array}{l}\text { Spatial } \\
\text { Models/I } \\
\text { ndices } \\
\text { and } \\
\text { Statistica } \\
1\end{array}$ & 396 & $\mathrm{AD}$ & $\begin{array}{l}\text { Positive } \\
\text { Association } \\
\text { Availability }\end{array}$ \\
\hline $\begin{array}{l}\text { Xie et } \\
\text { al., } 2018\end{array}$ & China & $\mathrm{PH}$ & $\mathrm{NH}$ & $\mathrm{C}$ & $\begin{array}{l}\text { Other } \\
\text { Land } \\
\text { Use Data }\end{array}$ & NA & Area/size & $\begin{array}{l}\text { Shortest/ } \\
\text { Nearest } \\
\text { distance }\end{array}$ & $\begin{array}{l}\text { Not } \\
\text { Used }\end{array}$ & $\begin{array}{l}\text { Not } \\
\text { Use } \\
\text { d }\end{array}$ & NA & NA & & NA & $\begin{array}{l}\text { cardio- } \\
\text { cerebral } \\
\text { vascular } \\
\text { diseases, } \\
\text { endocrine } \\
\text { diseases }\end{array}$ & $\begin{array}{l}\text { Statistica } \\
1\end{array}$ & 700 & $\mathrm{OA}$ & $\begin{array}{l}\text { Positive } \\
\text { Association } \\
\text { Accessibilit } \\
\mathrm{y}\end{array}$ \\
\hline $\begin{array}{l}\text { Yeager } \\
\text { et al., } \\
2018\end{array}$ & USA & $\mathrm{PH}$ & $\mathrm{NH}$ & $\mathrm{C}$ & Satellite & Yes & $\begin{array}{l}\text { NDVI } \\
\text { Value }\end{array}$ & NA & $\begin{array}{l}\text { Not } \\
\text { Used }\end{array}$ & $\begin{array}{l}\text { Not } \\
\text { Use } \\
\text { d }\end{array}$ & 250 & $\begin{array}{l}\text { Multi } \\
\text { Buffer }\end{array}$ & $\begin{array}{l}250 \\
1000\end{array}$ & NA & $\begin{array}{l}\text { cardiovasc } \\
\text { ular disease } \\
\text { biomarkers }\end{array}$ & $\begin{array}{l}\text { Statistica } \\
1\end{array}$ & 408 & $\mathrm{AD}$ & $\begin{array}{l}\text { Positive } \\
\text { Association } \\
\text { Availability }\end{array}$ \\
\hline
\end{tabular}




\begin{tabular}{|c|c|c|c|c|c|c|c|c|c|c|c|c|c|c|c|c|c|c|c|}
\hline $\begin{array}{l}\text { Yin, } \\
2013\end{array}$ & USA & $\mathrm{PH}$ & $\mathrm{NH}$ & $\mathrm{C}$ & $\begin{array}{l}\text { City } \\
\text { Council } \\
\text { Land } \\
\text { Use }\end{array}$ & Yes & Area/size & NA & $\begin{array}{l}\text { Not } \\
\text { Used }\end{array}$ & $\begin{array}{l}\text { Not } \\
\text { Use } \\
\mathrm{d}\end{array}$ & 805 & $\begin{array}{l}\text { Single } \\
\text { Buffer }\end{array}$ & & NA & Walking & $\begin{array}{l}\text { Simulati } \\
\text { on and } \\
\text { Statistica } \\
1\end{array}$ & NA & NA & $\begin{array}{l}\text { Mixed } \\
\text { Association } \\
\mathrm{s}\end{array}$ \\
\hline $\begin{array}{l}\text { Zandieh } \\
\text { et al., } \\
2017\end{array}$ & UK & $\mathrm{PH}$ & $\mathrm{DC}$ & $\mathrm{C}$ & $\begin{array}{l}\text { MasterM } \\
\text { ap }\end{array}$ & Yes & Percentage & $\begin{array}{l}\text { Fixed } \\
\text { Distance }\end{array}$ & $\begin{array}{l}\text { Not } \\
\text { Used }\end{array}$ & $\begin{array}{l}\text { Not } \\
\text { Use } \\
\mathrm{d}\end{array}$ & 2000 & $\begin{array}{l}\text { Single } \\
\text { Buffer }\end{array}$ & & GPS & PA & $\begin{array}{l}\text { Statistica } \\
1\end{array}$ & 173 & $\mathrm{OA}$ & $\begin{array}{l}\text { Positive } \\
\text { Association } \\
\text { Accessibilit } \\
\text { y }\end{array}$ \\
\hline $\begin{array}{l}\text { Zhai } \\
\text { and } \\
\text { Baran, } \\
2016\end{array}$ & China & $\mathrm{PH}$ & $\begin{array}{l}\text { Not } \\
\text { Av } \\
\text { aila } \\
\text { ble }\end{array}$ & $\mathrm{C}$ & $\begin{array}{l}\text { Other } \\
\text { Land } \\
\text { Use Data }\end{array}$ & NA & NA & $\begin{array}{l}\text { Shortest/ } \\
\text { Nearest } \\
\text { distance }\end{array}$ & Used & $\begin{array}{l}\text { Not } \\
\text { Use } \\
\mathrm{d}\end{array}$ & NA & NA & & GPS & $\begin{array}{l}\text { PA, } \\
\text { Walking }\end{array}$ & $\begin{array}{l}\text { Spatial } \\
\text { Models/I } \\
\text { ndices } \\
\text { and } \\
\text { Statistica } \\
1\end{array}$ & 75 & $\mathrm{OA}$ & $\begin{array}{l}\text { Positive } \\
\text { Association } \\
\text { Accessibilit } \\
\text { y }\end{array}$ \\
\hline $\begin{array}{l}\text { Beyer et } \\
\text { al., } 2014\end{array}$ & USA & $\begin{array}{l}\mathrm{M} \\
\mathrm{H}\end{array}$ & $\mathrm{NH}$ & C & Satellite & Yes & Percentage & NA & $\begin{array}{l}\text { Not } \\
\text { Used }\end{array}$ & $\begin{array}{l}\text { Not } \\
\text { Use } \\
\text { d }\end{array}$ & NA & NA & & NA & Depression & $\begin{array}{l}\text { Statistica } \\
1\end{array}$ & 2479 & $\mathrm{AD}$ & $\begin{array}{l}\text { Positive } \\
\text { Association } \\
\text { Availability }\end{array}$ \\
\hline $\begin{array}{l}\text { Dzhamb } \\
\text { ov et al., } \\
\text { 2018a }\end{array}$ & $\begin{array}{l}\text { Bulgari } \\
\text { a }\end{array}$ & $\begin{array}{l}\mathrm{M} \\
\mathrm{H}\end{array}$ & $\mathrm{NH}$ & C & Satellite & Yes & $\begin{array}{l}\text { NDVI } \\
\text { Value }\end{array}$ & $\begin{array}{l}\text { Shortest/ } \\
\text { Nearest } \\
\text { distance }\end{array}$ & $\begin{array}{l}\text { Not } \\
\text { Used }\end{array}$ & $\begin{array}{l}\text { Use } \\
\mathrm{d}\end{array}$ & 500 & $\begin{array}{l}\text { Multi } \\
\text { Buffer }\end{array}$ & $\begin{array}{c}50 \\
100 \\
300 \\
500 \\
1000\end{array}$ & NA & $\begin{array}{l}\text { Mental } \\
\text { health }\end{array}$ & $\begin{array}{l}\text { Statistica } \\
1\end{array}$ & 399 & $\mathrm{AD}$ & $\begin{array}{l}\text { Mixed } \\
\text { Association } \\
\mathrm{s}\end{array}$ \\
\hline $\begin{array}{l}\text { Dzhamb } \\
\text { ov et al., } \\
\text { 2018c }\end{array}$ & $\begin{array}{l}\text { Bulgari } \\
\text { a }\end{array}$ & $\begin{array}{l}\mathrm{M} \\
\mathrm{H}\end{array}$ & $\mathrm{NH}$ & C & Satellite & Yes & $\begin{array}{l}\text { NDVI and } \\
\text { Tree } \\
\text { canopy }\end{array}$ & $\begin{array}{l}\text { Shortest/ } \\
\text { Nearest } \\
\text { distance }\end{array}$ & $\begin{array}{l}\text { Not } \\
\text { Used }\end{array}$ & $\begin{array}{l}\text { Not } \\
\text { Use } \\
\text { d }\end{array}$ & 300 & $\begin{array}{l}\text { Multi } \\
\text { Buffer }\end{array}$ & $\begin{array}{l}100 \\
300 \\
500\end{array}$ & NA & GHQ-12 & $\begin{array}{l}\text { Statistica } \\
1\end{array}$ & 720 & $\mathrm{AD}$ & $\begin{array}{l}\text { Mixed } \\
\text { Association } \\
\mathrm{s}\end{array}$ \\
\hline $\begin{array}{l}\text { Gascon } \\
\text { et al., } \\
2018\end{array}$ & Spain & $\begin{array}{l}\mathrm{M} \\
\mathrm{H}\end{array}$ & $\mathrm{NH}$ & $\mathrm{C}$ & Satellite & Yes & $\begin{array}{l}\text { NDVI and } \\
\text { Area }\end{array}$ & $\begin{array}{l}\text { Fixed } \\
\text { Distance }\end{array}$ & $\begin{array}{l}\text { Not } \\
\text { Used }\end{array}$ & $\begin{array}{l}\text { Not } \\
\text { Use } \\
\text { d }\end{array}$ & 300 & $\begin{array}{l}\text { Multi } \\
\text { Buffer }\end{array}$ & $\begin{array}{c}100 \\
300 \\
500\end{array}$ & NA & $\begin{array}{l}\text { Survey } \\
\text { Developed } \\
\text { by the team }\end{array}$ & $\begin{array}{l}\text { Statistica } \\
1\end{array}$ & 958 & $\mathrm{AD}$ & $\begin{array}{l}\text { Mixed } \\
\text { Association } \\
\mathrm{s}\end{array}$ \\
\hline $\begin{array}{l}\text { Helbich } \\
\text { et al., } \\
2018\end{array}$ & $\begin{array}{l}\text { Netherl } \\
\text { ands }\end{array}$ & $\begin{array}{l}\mathrm{M} \\
\mathrm{H}\end{array}$ & $\mathrm{DC}$ & $\mathrm{C}$ & $\begin{array}{l}\text { Other } \\
\text { Land } \\
\text { Use Data }\end{array}$ & NA & Percentage & $\begin{array}{l}\text { Shortest/ } \\
\text { Nearest } \\
\text { distance }\end{array}$ & $\begin{array}{l}\text { Not } \\
\text { Used }\end{array}$ & $\begin{array}{l}\text { Not } \\
\text { Use } \\
\text { d }\end{array}$ & NA & NA & & NA & $\begin{array}{l}\text { Statistics } \\
\text { Netherland } \\
\mathrm{s}\end{array}$ & $\begin{array}{l}\text { Statistica } \\
1\end{array}$ & 398 & $\mathrm{AD}$ & $\begin{array}{l}\text { Positive } \\
\text { Association } \\
\text { Availability }\end{array}$ \\
\hline $\begin{array}{l}\text { Laatikai } \\
\text { nen et } \\
\text { al., } 2017\end{array}$ & Finland & $\begin{array}{l}\mathrm{M} \\
\mathrm{H}\end{array}$ & $\mathrm{DC}$ & $\mathrm{C}$ & $\begin{array}{l}\text { WebMap } \\
\text { s }\end{array}$ & Yes & $\begin{array}{l}\text { Area and } \\
\text { Numbers }\end{array}$ & $\begin{array}{l}\text { Shortest/ } \\
\text { Nearest } \\
\text { distance }\end{array}$ & $\begin{array}{l}\text { Not } \\
\text { Used }\end{array}$ & $\begin{array}{l}\text { Not } \\
\text { Use } \\
\text { d }\end{array}$ & 50 & $\begin{array}{l}\text { Single } \\
\text { Buffer }\end{array}$ & & $\begin{array}{l}\text { Web- } \\
\text { GIS/PPGI } \\
\text { S }\end{array}$ & $\begin{array}{l}\text { Positive } \\
\text { places }\end{array}$ & $\begin{array}{l}\text { Statistica } \\
1\end{array}$ & 3791 & $\begin{array}{l}\mathrm{AD} \\
\text { and } \\
\mathrm{CH}\end{array}$ & $\begin{array}{l}\text { Mixed } \\
\text { Association } \\
\mathrm{s}\end{array}$ \\
\hline $\begin{array}{l}\text { Markev } \\
\text { ych et } \\
\text { al., } \\
\text { 2014a }\end{array}$ & $\begin{array}{l}\text { German } \\
\text { y }\end{array}$ & $\begin{array}{l}\mathrm{M} \\
\mathrm{H}\end{array}$ & $\mathrm{NH}$ & $\mathrm{L}$ & $\begin{array}{l}\text { Other } \\
\text { Land } \\
\text { Use Data }\end{array}$ & NA & NA & $\begin{array}{l}\text { Shortest/ } \\
\text { Nearest } \\
\text { distance }\end{array}$ & $\begin{array}{l}\text { Not } \\
\text { Used }\end{array}$ & $\begin{array}{l}\text { Not } \\
\text { Use } \\
\text { d }\end{array}$ & 500 & $\begin{array}{l}\text { Single } \\
\text { Buffer }\end{array}$ & & NA & $\begin{array}{l}\text { Hyperactivi } \\
\text { ty, mental } \\
\text { health }\end{array}$ & $\begin{array}{l}\text { Statistica } \\
1\end{array}$ & 1931 & $\mathrm{CH}$ & $\begin{array}{l}\text { Mixed } \\
\text { Association } \\
\mathrm{s}\end{array}$ \\
\hline $\begin{array}{l}\text { McEach } \\
\text { an et al., } \\
2015\end{array}$ & UK & $\begin{array}{l}\mathrm{M} \\
\mathrm{H}\end{array}$ & $\mathrm{NH}$ & $\mathrm{C}$ & Satellite & Yes & $\begin{array}{l}\text { NDVI } \\
\text { Value }\end{array}$ & $\begin{array}{l}\text { Fixed } \\
\text { Distance }\end{array}$ & $\begin{array}{l}\text { Not } \\
\text { Used }\end{array}$ & $\begin{array}{l}\text { Not } \\
\text { Use } \\
\text { d }\end{array}$ & 100 & $\begin{array}{l}\text { Multi } \\
\text { Buffer }\end{array}$ & $\begin{array}{l}100 \\
300 \\
500\end{array}$ & NA & Depression & $\begin{array}{l}\text { Statistica } \\
1\end{array}$ & 7547 & $\mathrm{AD}$ & $\begin{array}{l}\text { Positive } \\
\text { Availability } \\
\text { And } \\
\text { Accessibilit } \\
\text { y }\end{array}$ \\
\hline $\begin{array}{l}\text { Mukher } \\
\text { hee et } \\
\text { al., } 2017\end{array}$ & India & $\begin{array}{l}\mathrm{M} \\
\mathrm{H}\end{array}$ & $\mathrm{NH}$ & $\mathrm{C}$ & Satellite & Yes & Area/size & $\begin{array}{l}\text { Shortest/ } \\
\text { Nearest } \\
\text { distance }\end{array}$ & $\begin{array}{l}\text { Not } \\
\text { Used }\end{array}$ & $\begin{array}{l}\text { Not } \\
\text { Use } \\
\mathrm{d}\end{array}$ & 1000 & $\begin{array}{l}\text { Multi } \\
\text { Buffer }\end{array}$ & $\begin{array}{l}234, \\
561, \\
1750\end{array}$ & NA & Depression & $\begin{array}{l}\text { Statistica } \\
1\end{array}$ & 1208 & $\mathrm{AD}$ & $\begin{array}{l}\text { Positive } \\
\text { Availability } \\
\text { And } \\
\text { Accessibilit } \\
\text { y }\end{array}$ \\
\hline
\end{tabular}




\begin{tabular}{|c|c|c|c|c|c|c|c|c|c|c|c|c|c|c|c|c|c|c|c|}
\hline $\begin{array}{l}\text { Nutsfor } \\
\text { d et al., } \\
2016\end{array}$ & $\begin{array}{l}\text { New } \\
\text { Zealand }\end{array}$ & $\begin{array}{l}\mathrm{M} \\
\mathrm{H}\end{array}$ & $\mathrm{NH}$ & $\mathrm{C}$ & $\begin{array}{l}\text { Other } \\
\text { Land } \\
\text { Use Data }\end{array}$ & Yes & NA & NA & Used & $\begin{array}{l}\text { Not } \\
\text { Use } \\
\text { d }\end{array}$ & 300 & $\begin{array}{l}\text { Multi } \\
\text { Buffer }\end{array}$ & $\begin{array}{l}300 \\
3000 \\
6000\end{array}$ & NA & Stress & $\begin{array}{l}\text { Statistica } \\
1\end{array}$ & 442 & $\mathrm{AD}$ & $\begin{array}{l}\text { Positive } \\
\text { Association } \\
\text { Visibility }\end{array}$ \\
\hline $\begin{array}{l}\text { Quynh } \\
\text { Huynh } \\
\text { et al. } \\
2013\end{array}$ & Canada & $\begin{array}{l}\mathrm{M} \\
\mathrm{H}\end{array}$ & $\mathrm{NH}$ & $\mathrm{C}$ & $\begin{array}{l}\text { Other } \\
\text { Land } \\
\text { Use Data }\end{array}$ & Yes & Percentage & NA & $\begin{array}{l}\text { Not } \\
\text { Used }\end{array}$ & $\begin{array}{l}\text { Not } \\
\text { Use } \\
\text { d }\end{array}$ & 5000 & $\begin{array}{l}\text { Single } \\
\text { Buffer }\end{array}$ & & NA & $\begin{array}{l}\text { Mental } \\
\text { wellbeing }\end{array}$ & $\begin{array}{l}\text { Statistica } \\
1\end{array}$ & 17249 & $\mathrm{CH}$ & $\begin{array}{l}\text { Insignifican } \\
\mathrm{t} \\
\text { Association }\end{array}$ \\
\hline $\begin{array}{l}\text { Sarkar } \\
\text { et al., } \\
2013\end{array}$ & UK & $\begin{array}{l}\mathrm{M} \\
\mathrm{H}\end{array}$ & $\mathrm{NH}$ & $\mathrm{C}$ & Satellite & Yes & $\begin{array}{l}\text { NDVI } \\
\text { Value }\end{array}$ & $\begin{array}{l}\text { Both } \\
\text { Fixed } \\
\text { and } \\
\text { Shortest } \\
\text { Distances }\end{array}$ & $\begin{array}{l}\text { Not } \\
\text { Used }\end{array}$ & $\begin{array}{l}\text { Not } \\
\text { Use } \\
\mathrm{d}\end{array}$ & 500 & $\begin{array}{l}\text { Single } \\
\text { Buffer }\end{array}$ & & NA & GHQ 30 & $\begin{array}{l}\text { Spatial } \\
\text { Models/I } \\
\text { ndices } \\
\text { and } \\
\text { Statistica } \\
1\end{array}$ & 687 & $\mathrm{AD}$ & $\begin{array}{l}\text { Mixed } \\
\text { Association } \\
\mathrm{s}\end{array}$ \\
\hline $\begin{array}{l}\text { Sarkar } \\
\text { et al., } \\
2018\end{array}$ & UK & $\begin{array}{l}\mathrm{M} \\
\mathrm{H}\end{array}$ & $\mathrm{NH}$ & $\mathrm{C}$ & Satellite & Yes & $\begin{array}{l}\text { NDVI } \\
\text { Value }\end{array}$ & $\mathrm{NA}$ & $\begin{array}{l}\text { Not } \\
\text { Used }\end{array}$ & $\begin{array}{l}\text { Not } \\
\text { Use } \\
\text { d }\end{array}$ & 500 & $\begin{array}{l}\text { Single } \\
\text { Buffer }\end{array}$ & & $\mathrm{NA}$ & Depression & $\begin{array}{l}\text { Statistica } \\
1\end{array}$ & 94879 & $\mathrm{AD}$ & $\begin{array}{l}\text { Positive } \\
\text { Association } \\
\text { Availability }\end{array}$ \\
\hline $\begin{array}{l}\text { Sturm } \\
\text { and } \\
\text { Cohen, } \\
2014\end{array}$ & USA & $\begin{array}{l}\mathrm{M} \\
\mathrm{H}\end{array}$ & $\mathrm{NH}$ & C & $\begin{array}{l}\text { Other } \\
\text { Land } \\
\text { Use Data }\end{array}$ & NA & NA & $\begin{array}{l}\text { Fixed } \\
\text { Distance }\end{array}$ & $\begin{array}{l}\text { Not } \\
\text { Used }\end{array}$ & $\begin{array}{l}\text { Not } \\
\text { Use } \\
\text { d }\end{array}$ & 400 & $\begin{array}{l}\text { Multi } \\
\text { Buffer }\end{array}$ & $\begin{array}{l}400 \\
800 \\
1600\end{array}$ & NA & MHI-5 & $\begin{array}{l}\text { Statistica } \\
1\end{array}$ & 1070 & $\mathrm{AD}$ & $\begin{array}{l}\text { Positive } \\
\text { Association } \\
\text { Accessibilit } \\
\text { y }\end{array}$ \\
\hline $\begin{array}{l}\text { Triguer } \\
\text { o-Mas } \\
\text { et al., } \\
\text { 2017a }\end{array}$ & Multi & $\begin{array}{l}\mathrm{M} \\
\mathrm{H}\end{array}$ & $\mathrm{NH}$ & $\mathrm{C}$ & Satellite & Yes & $\begin{array}{l}\text { NDVI and } \\
\text { Percentage }\end{array}$ & NA & $\begin{array}{l}\text { Not } \\
\text { Used }\end{array}$ & $\begin{array}{l}\text { Not } \\
\text { Use } \\
\text { d }\end{array}$ & 50 & $\begin{array}{l}\text { Multi } \\
\text { Buffer }\end{array}$ & $\begin{array}{l}50 \\
300\end{array}$ & $\begin{array}{l}\text { Smartpho } \\
\text { ne }\end{array}$ & Stress & $\begin{array}{l}\text { Statistica } \\
1\end{array}$ & 406 & $\mathrm{AD}$ & $\begin{array}{l}\text { Mixed } \\
\text { Association } \\
\mathrm{s}\end{array}$ \\
\hline $\begin{array}{l}\text { Van den } \\
\text { Berg et } \\
\text { al., 2017 }\end{array}$ & UK & $\begin{array}{l}\mathrm{M} \\
\mathrm{H}\end{array}$ & $\mathrm{NH}$ & C & Satellite & Yes & $\begin{array}{l}\text { NDVI } \\
\text { Value }\end{array}$ & NA & $\begin{array}{l}\text { Not } \\
\text { Used }\end{array}$ & $\begin{array}{l}\text { Use } \\
\text { d }\end{array}$ & 300 & $\begin{array}{l}\text { Single } \\
\text { Buffer }\end{array}$ & & NA & $\begin{array}{l}\text { GHQ-12, } \\
\text { SF-36 }\end{array}$ & $\begin{array}{l}\text { Statistica } \\
1\end{array}$ & 3748 & $\mathrm{AD}$ & $\begin{array}{l}\text { Mixed } \\
\text { Association } \\
\mathrm{s}\end{array}$ \\
\hline $\begin{array}{l}\text { Wood et } \\
\text { al., } 2017\end{array}$ & $\begin{array}{l}\text { Australi } \\
\text { a }\end{array}$ & $\begin{array}{l}\mathrm{M} \\
\mathrm{H}\end{array}$ & $\mathrm{NH}$ & $\mathrm{L}$ & $\begin{array}{l}\text { Other } \\
\text { Land } \\
\text { Use Data }\end{array}$ & NA & $\begin{array}{l}\text { Area and } \\
\text { Numbers } \\
\text { of GBS }\end{array}$ & $\begin{array}{l}\text { Fixed } \\
\text { Distance }\end{array}$ & $\begin{array}{l}\text { Not } \\
\text { Used }\end{array}$ & $\begin{array}{l}\text { Not } \\
\text { Use } \\
\text { d }\end{array}$ & 1600 & $\begin{array}{l}\text { Single } \\
\text { Buffer }\end{array}$ & & NA & $\begin{array}{l}\text { WEMWBS } \\
\text { scale for } \\
\text { mental } \\
\text { health }\end{array}$ & $\begin{array}{l}\text { Statistica } \\
1\end{array}$ & 492 & $\mathrm{AD}$ & $\begin{array}{l}\text { Positive } \\
\text { Availability } \\
\text { And } \\
\text { Accessibilit } \\
\text { y }\end{array}$ \\
\hline $\begin{array}{l}\text { Zhang } \\
\text { et al., } \\
2015\end{array}$ & $\begin{array}{l}\text { Netherl } \\
\text { ands }\end{array}$ & $\begin{array}{l}\mathrm{M} \\
\mathrm{H}\end{array}$ & $\mathrm{NH}$ & C & Satellite & NA & Percentage & NA & $\begin{array}{l}\text { Not } \\
\text { Used }\end{array}$ & $\begin{array}{l}\text { Not } \\
\text { Use } \\
\text { d }\end{array}$ & 400 & $\begin{array}{l}\text { Single } \\
\text { Buffer }\end{array}$ & & NA & MHI-5 & $\begin{array}{l}\text { Statistica } \\
1\end{array}$ & 223 & $\mathrm{AD}$ & $\begin{array}{l}\text { Positive } \\
\text { Association } \\
\text { Availability }\end{array}$ \\
\hline $\begin{array}{l}\text { Browni } \\
\text { ng and } \\
\text { Rigolon, } \\
2018\end{array}$ & USA & G & $\mathrm{DC}$ & $\mathrm{C}$ & Satellite & NA & $\begin{array}{l}\text { NDVI and } \\
\text { Tree } \\
\text { canopy }\end{array}$ & NA & $\begin{array}{l}\text { Not } \\
\text { Used }\end{array}$ & $\begin{array}{l}\text { Not } \\
\text { Use } \\
\text { d }\end{array}$ & NA & & & NA & $\begin{array}{l}\text { BMI and } \\
\text { Mental } \\
\text { health } \\
\text { (binary), } \\
\text { later on } \\
\text { aggregated } \\
\text { to city } \\
\text { level. }\end{array}$ & $\begin{array}{l}\text { Spatial } \\
\text { Models/I } \\
\text { ndices } \\
\text { and } \\
\text { Statistica } \\
1\end{array}$ & 496 & $\mathrm{AD}$ & $\begin{array}{l}\text { Positive } \\
\text { Association } \\
\text { Availability }\end{array}$ \\
\hline $\begin{array}{l}\text { Christia } \\
\text { n et al., } \\
2017\end{array}$ & $\begin{array}{l}\text { Australi } \\
\text { a }\end{array}$ & G & $\mathrm{NH}$ & $\mathrm{C}$ & $\begin{array}{l}\text { Other } \\
\text { Land } \\
\text { Use Data }\end{array}$ & Yes & NA & $\begin{array}{l}\text { Shortest/ } \\
\text { Nearest } \\
\text { distance }\end{array}$ & $\begin{array}{l}\text { Not } \\
\text { Used }\end{array}$ & $\begin{array}{l}\text { Not } \\
\text { Use } \\
\mathrm{d}\end{array}$ & NA & NA & & NA & $\begin{array}{l}\text { AEDC } \\
\text { Child } \\
\text { Developme } \\
\text { nt Score }\end{array}$ & $\begin{array}{l}\text { Statistica } \\
1\end{array}$ & 23395 & $\mathrm{CH}$ & $\begin{array}{l}\text { Positive } \\
\text { Association } \\
\text { Accessibilit } \\
\mathrm{y}\end{array}$ \\
\hline
\end{tabular}




\begin{tabular}{|c|c|c|c|c|c|c|c|c|c|c|c|c|c|c|c|c|c|c|c|}
\hline $\begin{array}{l}\text { Coppel } \\
\text { and } \\
\text { Wustem } \\
\text { ann, } \\
2017\end{array}$ & $\begin{array}{l}\text { German } \\
\text { y }\end{array}$ & G & $\mathrm{NH}$ & $\mathrm{C}$ & $\begin{array}{l}\text { Other } \\
\text { Land } \\
\text { Use Data }\end{array}$ & Yes & Percentage & $\begin{array}{l}\text { Shortest/ } \\
\text { Nearest } \\
\text { distance }\end{array}$ & $\begin{array}{l}\text { Not } \\
\text { Used }\end{array}$ & $\begin{array}{l}\text { Not } \\
\text { Use } \\
\text { d }\end{array}$ & 250 & $\begin{array}{l}\text { Single } \\
\text { Buffer }\end{array}$ & & NA & $\begin{array}{l}\text { General } \\
\text { health }\end{array}$ & $\begin{array}{l}\text { Statistica } \\
1\end{array}$ & 874 & $\mathrm{AD}$ & $\begin{array}{l}\text { Positive } \\
\text { Availability } \\
\text { And } \\
\text { Accessibilit } \\
\text { y }\end{array}$ \\
\hline $\begin{array}{l}\text { Egorov } \\
\text { et al., } \\
2017\end{array}$ & USA & G & $\mathrm{NH}$ & $\mathrm{C}$ & $\begin{array}{l}\text { Other } \\
\text { Land } \\
\text { Use Data }\end{array}$ & Yes & Percentage & NA & $\begin{array}{l}\text { Not } \\
\text { Used }\end{array}$ & $\begin{array}{l}\text { Not } \\
\text { Use } \\
\mathrm{d}\end{array}$ & 500 & $\begin{array}{l}\text { Single } \\
\text { Buffer }\end{array}$ & & NA & $\begin{array}{l}\text { Allostatic } \\
\text { load related } \\
\text { biomarkers, } \\
\text { BMI, and } \\
\text { depression }\end{array}$ & $\begin{array}{l}\text { Spatial } \\
\text { Models/I } \\
\text { ndices } \\
\text { and } \\
\text { Statistica } \\
1\end{array}$ & 206 & $\mathrm{AD}$ & $\begin{array}{l}\text { Positive } \\
\text { Association } \\
\text { Availability }\end{array}$ \\
\hline $\begin{array}{l}\text { Ihlebæk } \\
\text { et al., } \\
2018\end{array}$ & Norway & G & $\mathrm{NH}$ & $\mathrm{C}$ & Satellite & NA & Percentage & NA & $\begin{array}{l}\text { Not } \\
\text { Used }\end{array}$ & $\begin{array}{l}\text { Not } \\
\text { Use } \\
\mathrm{d}\end{array}$ & NA & NA & & NA & $\begin{array}{l}\text { Mental } \\
\text { disorder, } \\
\text { asthma, } \\
\text { Diabetes } 2\end{array}$ & $\begin{array}{l}\text { Statistica } \\
1\end{array}$ & 8638 & $\mathrm{AD}$ & $\begin{array}{l}\text { Mixed } \\
\text { Association } \\
\mathrm{s}\end{array}$ \\
\hline $\begin{array}{l}\text { Jonker } \\
\text { et al., } \\
2014\end{array}$ & $\begin{array}{l}\text { Netherl } \\
\text { ands }\end{array}$ & G & $\mathrm{NH}$ & $\mathrm{C}$ & $\begin{array}{l}\text { Other } \\
\text { Land } \\
\text { Use Data }\end{array}$ & NA & Percentage & $\begin{array}{l}\text { Shortest/ } \\
\text { Nearest } \\
\text { distance }\end{array}$ & $\begin{array}{l}\text { Not } \\
\text { Used }\end{array}$ & $\begin{array}{l}\text { Not } \\
\text { Use } \\
\text { d }\end{array}$ & NA & NA & & NA & $\begin{array}{l}\text { Life } \\
\text { expectancy }\end{array}$ & $\begin{array}{l}\text { Statistica } \\
1\end{array}$ & 1190 & $\mathrm{AD}$ & $\begin{array}{l}\text { Mixed } \\
\text { Association } \\
\mathrm{s}\end{array}$ \\
\hline $\begin{array}{l}\text { Kardan } \\
\text { et al., } \\
2015\end{array}$ & Canada & G & $\mathrm{NH}$ & $\mathrm{C}$ & Satellite & NA & $\begin{array}{l}\text { Tree } \\
\text { canopy }\end{array}$ & NA & $\begin{array}{l}\text { Not } \\
\text { Used }\end{array}$ & $\begin{array}{l}\text { Not } \\
\text { Use } \\
\mathrm{d}\end{array}$ & NA & NA & & NA & $\begin{array}{l}\text { Health } \\
\text { perception, } \\
\text { cardio- } \\
\text { metabolic }\end{array}$ & $\begin{array}{l}\text { Statistica } \\
1\end{array}$ & 31109 & $\mathrm{AD}$ & $\begin{array}{l}\text { Positive } \\
\text { Association } \\
\text { Availability }\end{array}$ \\
\hline $\begin{array}{l}\text { Reid et } \\
\text { al., } 2018\end{array}$ & USA & G & $\mathrm{NH}$ & C & Satellite & Yes & $\begin{array}{l}\text { NDVI and } \\
\text { Percentage }\end{array}$ & NA & $\begin{array}{l}\text { Not } \\
\text { Used }\end{array}$ & $\begin{array}{l}\text { Not } \\
\text { Use } \\
\text { d }\end{array}$ & 1000 & $\begin{array}{l}\text { Multi } \\
\text { Buffer }\end{array}$ & $\begin{array}{c}100 \\
300 \\
500 \\
1000 \\
2000\end{array}$ & NA & $\begin{array}{l}\text { Self- } \\
\text { reported } \\
\text { overall } \\
\text { health }\end{array}$ & $\begin{array}{l}\text { Statistica } \\
1\end{array}$ & 1281 & $\mathrm{AD}$ & $\begin{array}{l}\text { Positive } \\
\text { Association } \\
\text { Availability }\end{array}$ \\
\hline $\begin{array}{l}\text { Su et } \\
\text { al., } 2016\end{array}$ & China & G & $\mathrm{DC}$ & $\mathrm{C}$ & $\begin{array}{l}\text { Other } \\
\text { Land } \\
\text { Use Data }\end{array}$ & NA & Area/size & $\mathrm{NA}$ & $\begin{array}{l}\text { Not } \\
\text { Used }\end{array}$ & $\begin{array}{l}\text { Not } \\
\text { Use } \\
\text { d }\end{array}$ & 600 & $\begin{array}{l}\text { Single } \\
\text { Buffer }\end{array}$ & & $\mathrm{NA}$ & $\begin{array}{l}\text { Population } \\
\text { health }\end{array}$ & $\begin{array}{l}\text { Spatial } \\
\text { Models/I } \\
\text { ndices } \\
\text { and } \\
\text { Statistica } \\
1\end{array}$ & 57 & NA & $\begin{array}{l}\text { Positive } \\
\text { Association } \\
\text { Availability }\end{array}$ \\
\hline $\begin{array}{l}\text { Taylor } \\
\text { et al., } \\
2018\end{array}$ & $\begin{array}{l}\text { Australi } \\
\text { a }\end{array}$ & G & $\mathrm{NH}$ & C & Satellite & NA & $\begin{array}{l}\text { NDVI } \\
\text { Value }\end{array}$ & NA & Used & $\begin{array}{l}\text { Not } \\
\text { Use } \\
\text { d }\end{array}$ & NA & NA & & NA & $\begin{array}{l}\text { WHO-5, } \\
\text { wellbeing, } \\
\text { and overall } \\
\text { health }\end{array}$ & $\begin{array}{l}\text { Qualitati } \\
\text { ve and } \\
\text { Statistica } \\
1\end{array}$ & 1819 & $\mathrm{AD}$ & $\begin{array}{l}\text { Mixed } \\
\text { Association } \\
\mathrm{s}\end{array}$ \\
\hline $\begin{array}{l}\text { Triguer } \\
\text { o-Mas } \\
\text { et al., } \\
2018\end{array}$ & Spain & G & $\mathrm{NH}$ & C & Satellite & Yes & $\begin{array}{l}\text { NDVI } \\
\text { Value }\end{array}$ & $\begin{array}{l}\text { Fixed } \\
\text { Distance }\end{array}$ & $\begin{array}{l}\text { Not } \\
\text { Used }\end{array}$ & $\begin{array}{l}\text { Not } \\
\text { Use } \\
\text { d }\end{array}$ & 300 & $\begin{array}{l}\text { Multi } \\
\text { Buffer }\end{array}$ & $\begin{array}{l}100 \\
300 \\
500\end{array}$ & NA & $\begin{array}{l}\text { GHQ-12, } \\
\text { SF-36, } \\
\text { Depression }\end{array}$ & $\begin{array}{l}\text { Statistica } \\
1\end{array}$ & 8793 & $\mathrm{AD}$ & $\begin{array}{l}\text { Positive } \\
\text { Availability } \\
\text { And } \\
\text { Accessibilit } \\
\text { y }\end{array}$ \\
\hline $\begin{array}{l}\text { van } \\
\text { Dillen et } \\
\text { al., } 2011\end{array}$ & $\begin{array}{l}\text { Netherl } \\
\text { ands }\end{array}$ & G & $\mathrm{NH}$ & $\mathrm{C}$ & Survey & NA & NA & $\begin{array}{l}\text { Both } \\
\text { Fixed } \\
\text { and } \\
\text { Shortest } \\
\text { Distances }\end{array}$ & Used & $\begin{array}{l}\text { Not } \\
\text { Use } \\
\mathrm{d}\end{array}$ & 500 & $\begin{array}{l}\text { Single } \\
\text { Buffer }\end{array}$ & & NA & $\begin{array}{l}\text { SF 36, } \\
\text { MHI-5 }\end{array}$ & $\begin{array}{l}\text { Statistica } \\
1\end{array}$ & 1641 & $\mathrm{AD}$ & $\begin{array}{l}\text { Positive } \\
\text { Accessibilit } \\
\text { y And } \\
\text { Visibility }\end{array}$ \\
\hline
\end{tabular}




\begin{tabular}{|c|c|c|c|c|c|c|c|c|c|c|c|c|c|c|c|c|c|c|c|}
\hline $\begin{array}{l}\text { Ward et } \\
\text { al., } 2017\end{array}$ & $\begin{array}{l}\text { New } \\
\text { Zealand }\end{array}$ & G & PR & C & $\begin{array}{l}\text { WebMap } \\
\text { s }\end{array}$ & NA & NA & NA & $\begin{array}{l}\text { Not } \\
\text { Used }\end{array}$ & $\begin{array}{l}\text { Use } \\
\mathrm{d}\end{array}$ & NA & NA & & $\begin{array}{l}\text { GPS and } \\
\text { Accelerom } \\
\text { eter }\end{array}$ & $\begin{array}{l}\text { PA, } \\
\text { Emotional } \\
\text { Wellbeing, } \\
\text { BMI }\end{array}$ & $\begin{array}{l}\text { Statistica } \\
1\end{array}$ & 78 & $\mathrm{CH}$ & $\begin{array}{l}\text { Mixed } \\
\text { Association } \\
\mathrm{s}\end{array}$ \\
\hline $\begin{array}{l}\text { White } \\
\text { et al., } \\
2017\end{array}$ & UK & G & $\mathrm{NH}$ & C & $\begin{array}{l}\text { Other } \\
\text { Land } \\
\text { Use Data }\end{array}$ & NA & Percentage & $\begin{array}{l}\text { Fixed } \\
\text { Distance }\end{array}$ & $\begin{array}{l}\text { Not } \\
\text { Used }\end{array}$ & $\begin{array}{l}\text { Use } \\
\mathrm{d}\end{array}$ & NA & NA & & NA & Wellbeing & $\begin{array}{l}\text { Statistica } \\
1\end{array}$ & 7272 & $\mathrm{AD}$ & $\begin{array}{l}\text { Mixed } \\
\text { Association } \\
\mathrm{s}\end{array}$ \\
\hline $\begin{array}{l}\text { Wu and } \\
\text { Jackson } \\
\text {, } 2018\end{array}$ & USA & G & $\mathrm{DC}$ & $\mathrm{C}$ & $\begin{array}{l}\text { Other } \\
\text { Land } \\
\text { Use Data }\end{array}$ & Yes & Percentage & NA & $\begin{array}{l}\text { Not } \\
\text { Used }\end{array}$ & $\begin{array}{l}\text { Not } \\
\text { Use } \\
\text { d }\end{array}$ & 50 & $\begin{array}{l}\text { Multi } \\
\text { Buffer }\end{array}$ & $\begin{array}{l}50 \\
100\end{array}$ & NA & Autism & $\begin{array}{l}\text { Spatial } \\
\text { Models/I } \\
\text { ndices } \\
\text { and } \\
\text { Statistica } \\
1\end{array}$ & NA & $\mathrm{CH}$ & $\begin{array}{l}\text { Positive } \\
\text { Association } \\
\text { Availability }\end{array}$ \\
\hline $\begin{array}{l}\text { Zhang } \\
\text { et al. } \\
2018\end{array}$ & China & G & PR & $\mathrm{C}$ & Satellite & NA & Percentage & $\begin{array}{l}\text { Shortest/ } \\
\text { Nearest } \\
\text { distance }\end{array}$ & $\begin{array}{l}\text { Not } \\
\text { Used }\end{array}$ & $\begin{array}{l}\text { Use } \\
\mathrm{d}\end{array}$ & 1000 & $\begin{array}{l}\text { Multi } \\
\text { Buffer }\end{array}$ & $\begin{array}{l}500 \\
1000\end{array}$ & NA & $\begin{array}{l}\text { SF } 36 \text { and } \\
\text { WHO-5 }\end{array}$ & $\begin{array}{l}\text { Statistica } \\
1\end{array}$ & 1003 & $\mathrm{AH}$ & $\begin{array}{l}\text { Positive } \\
\text { Availability } \\
\text { And } \\
\text { Accessibilit } \\
\text { y }\end{array}$ \\
\hline
\end{tabular}

Table 3S: List of confounding variables commonly used in the reviewed articles.

\begin{tabular}{|l|c|c|}
\hline Confounding Variables & Number of Studies considered & Percentage \\
\hline Age & 76 & 81.72 \\
\hline Gender & 69 & 74.19 \\
\hline Education & 46 & 49.46 \\
\hline Income & 35 & 37.63 \\
\hline Ethnicity & 25 & 26.88 \\
\hline Marital Status & 24 & 25.81 \\
\hline Smoking & 23 & 24.73 \\
\hline Race & 17 & 18.28 \\
\hline Employment & 16 & 17.20 \\
\hline SES & 11 & 11.83 \\
\hline Deprivation & 9 & 9.68 \\
\hline BMI & 6 & 6.45 \\
\hline Dog Ownership & 6 & 6.45 \\
\hline Parental Education & 6 & 6.45 \\
\hline Alcohol & 5 & 5.38 \\
\hline car ownership & 4 & 4.30 \\
\hline
\end{tabular}




\begin{tabular}{|c|c|c|}
\hline Physical activities & 4 & 4.30 \\
\hline Area/ region/city & 3 & 3.23 \\
\hline Duration of staying at home & 3 & 3.23 \\
\hline Family size & 3 & 3.23 \\
\hline Immigration/Migration Status & 3 & 3.23 \\
\hline Stressful life events & 3 & 3.23 \\
\hline Child $<12$ & 2 & 2.15 \\
\hline Child $<18$ & 2 & 2.15 \\
\hline Chronic disease & 2 & 2.15 \\
\hline Diabetes & 2 & 2.15 \\
\hline Number of years of residency & 2 & 2.15 \\
\hline Parental Asthma & 2 & 2.15 \\
\hline Poverty & 2 & 2.15 \\
\hline Season & 2 & 2.15 \\
\hline Access to shop & 1 & 1.08 \\
\hline Antibiotic Use & 1 & 1.08 \\
\hline Breast-feeding & 1 & 1.08 \\
\hline Civil Status & 1 & 1.08 \\
\hline Crime rate & 1 & 1.08 \\
\hline Depression & 1 & 1.08 \\
\hline Diet & 1 & 1.08 \\
\hline Disability & 1 & 1.08 \\
\hline Family History & 1 & 1.08 \\
\hline Good friend & 1 & 1.08 \\
\hline History of Coronary disease & 1 & 1.08 \\
\hline History of Stroke & 1 & 1.08 \\
\hline Home Ownership & 1 & 1.08 \\
\hline Homicide rate & 1 & 1.08 \\
\hline Household structure & 1 & 1.08 \\
\hline Hypertension & 1 & 1.08 \\
\hline Insurance & 1 & 1.08 \\
\hline Language & 1 & 1.08 \\
\hline Living in flat & 1 & 1.08 \\
\hline Medicaid & 1 & 1.08 \\
\hline Move House & 1 & 1.08 \\
\hline Occupation & 1 & 1.08 \\
\hline Orientation of rooms at home & 1 & 1.08 \\
\hline
\end{tabular}


Parental Care

Parental Hypertension

Park Visit

Pet

Preterm birth

Protestant

Rape rate

School Type

Screen time

Sibling

Social activities

Statin Use

Weight

\begin{tabular}{|l|l|}
\hline 1 & 1.08 \\
\hline 1 & 1.08 \\
\hline 1 & 1.08 \\
\hline 1 & 1.08 \\
\hline 1 & 1.08 \\
\hline 1 & 1.08 \\
\hline 1 & 1.08 \\
\hline 1 & 1.08 \\
\hline 1 & 1.08 \\
\hline & 1.08 \\
\hline 1 & 1.08 \\
\hline
\end{tabular}

